\title{
消化器疾患・検査
}

\section{D01 臨床胃癌症例とペプシノーゲン判定}

\section{大久保 俊治（おおくぼ しゅんじ）平鹿総合病院}

秋田県農村医学会「秋田県における血清PG值と胃疾患に関する共同研究班」

岸部 敶（北秋中央病院）他 共同研究班員

胃癌 ペプシノーゲン

\section{【緒言】}

秋田県農村医学会「秋田県における血清 PG值と胃疾患に関する共同研究班」におい て(1)PG胃集検方式の検討(2)外来発見胃癌に おけるPG判定の 2 研究を行った。そのうち (2)に関して報告する。

\section{【研究のまとめ】}

1. 厚生連9病院より男性422名、女性200 名、計622名が集積された。

2. 胃癌症例のPG陽性率（強陽性+陽性）は 住民に比し高率である。

3. 占拠部位、大きさ、深達度と陽性率との 関連は認めない。

4 、報告例中早期癌は52\%（m33\%、sm 19\%）を占めた。

5. 早期癌- I 型、進行癌-1型の典型的隆起 癌は強陽性が多数を占めた。

6. 組織型では、pap（乳頭状腺癌）で強陽 性が高い。

7. 分化型癌に強陽性がやや多いが、陽性率 では末分化型と差がない。

8. $\mathrm{m}$ 癌に限定すると、分化型の陽性率がや や高く、未分化型で陰性が多い。

9. 外来無症状群と間接胃集検では早期癌を 発見する機会が高い。

\section{【結論】}

1. 全癌のPG陽性率は約70\%と高值である が、PG単独胃集検では約30\%が偽陰性 となる。
2. 隆起型癌、分化型癌でPG陽性率がやや 高い傾向は見られたが、顕著ではない。

肉眼分類

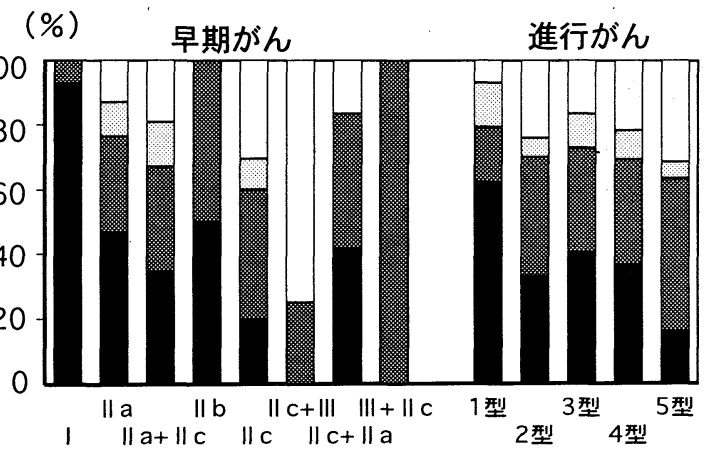

強陽性 陽性 (\%) 組 織分 類

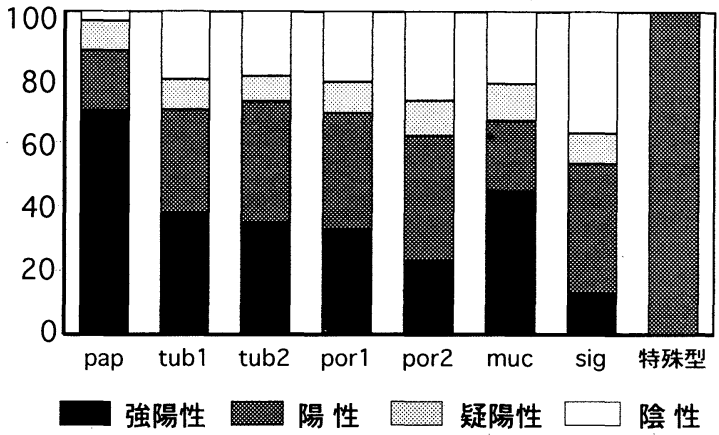

(\%)

深達度別発見状況

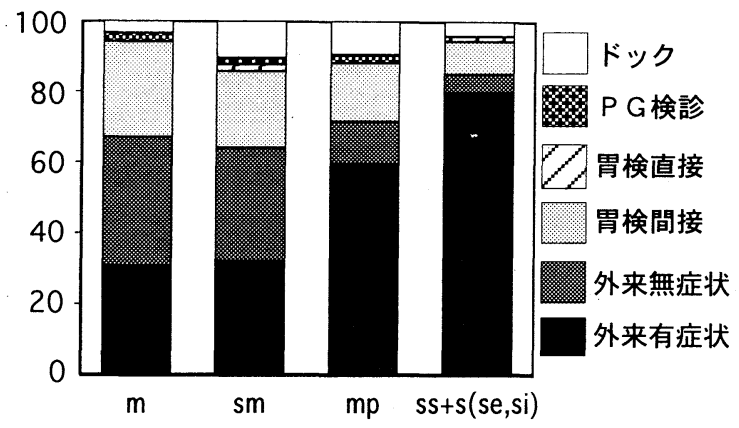


2D02 当地方における下血の検討

$$
\begin{aligned}
& \text { 小林一彦（こばやし かずひこ） } \\
& \text { 松阪中央総合病院 胃腸科 } \\
& \text { 田中匡介、黒田真紀子、小山 睦 }
\end{aligned}
$$

下血、大腸内視鏡。

【目的】消化管出血の中で大腸出血の占め る割合は約1/4といわれているが、近年そ の頻度が増加している。今回、臨床的に経 験する下血症例の疫学、病態について検討 してみた。

【対象及び方法】当院にて1998年1月か ら2000年3月までに下血を主訴に来院し、 下部消化管内視鏡検查を施行された 32 例 につき検討した。

【結果】下血を認めた332名の内訳は男性 154 例 (46.7\%) 、女性178名 $(53.3 \%)$ で、平均年齢（4歳９5 歳）は男性54.8 \pm 18.0 歳、女性は58.3 18 .2. 歳であった。 全体では下血の原因として痔核 98 例

$(29.5 \%)$ 、虚血性大腸炎 43 例 $(13.0 \%)$ 、 直腸炎 31 例 $(9.3 \%)$ 、大腸炎 29 例 $(8.7$ $\%$ ）、大腸媳室24例（7.3\%）、大腸潰瘍

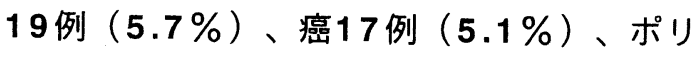
-プ14例 $(4.2 \%)$ 、炎症性腸疾患13 例 $(3.9 \%)$ 、直腸脱症候群 12 例 $(3.6 \%)$ 、 異常なし43例 $(13.0 \%)$ であった。当地 方では、我が国の臨床統計と比較し、ポリ ープと癌及び炎症性腸疾患の頻度が低く、 虚血性大腸炎と大腸媳室及び痔核の頻度が 高い傾向にあった。男女にて比較すると出 血の原因として大腸媳室症は男性 16/155 例 $(10.3 \%)$ 、女性 $8 / 178$ 例 $(4.4 \%)$ と男性に多い傾向があった。さらに65歳 以上（高齢者；120例）とそれ以下（212 例）についても検討を加えた。大腸出血の
原因疾患として65歳以下と比較し、高齢 者では癌（11例、9.2\%）、虚血性大腸炎 (19例、15.8\%) 、直腸脱症候群（8例、 $1.9 \% ）$ が多い傾向にあった。65歳以下で は炎症性腸疾患（13 例、6.1\%）、大腸潰 瘍（18例、8.5\%) が多い傾向にあった。 【結語】当地方においては虚血性大腸炎、 大腸媳室、痔核の頻度が高い傾向にあった。 今後も全年齢に対し、積極的に大腸内視鏡 を施行し、症例を積み重ねる必要があると 考えられた。 
2D03 便人 $\mathrm{Hb}$ 反応について

\section{中田恭文（なかたやするみ）}

JA 徳島厚生連 阿南共栄病院 臨床検査部 高山郁朗 松田守啓 南與志子 三浦真司 根東朱美

便人 $\mathrm{Hb}$ 反応について

JA 徳島厚生連 阿南共栄病院

臨床検查部 ○中田恭文 高山郁朗 松田守啓 南與志子 三浦真司

$\mathrm{JA}$ 徳島厚生連 阿波病院

臨床検査部根東朱美

平成 10 年度徳島県厚生連集団健診での、 和光純薬工業株式会社のイムノゴールド Hem を用いた免疫学的便潜血反応検査（金 コロイド比色法) の実施人数は、総受診者数 5,983 名、男性 2,680 名、女性 3,303 名で、 最も受診者数が多い年齢層は男性 40 歳代、 女性は 60 歳代であった。

検査が陽性で要精密検査となった人数は男 性 211 名 $(7.9 \%)$ 、女性 200 名 $(6.1 \%)$ 、計 411 名 $(6.9 \%)$ で、このうち精密検查のため 受診したのは $59 \%$ (411名中 243 名) だった。 精密検査方法の内訳は、大腸内視鏡のみ 161 名、注晹透視のみ 56 名、便潜血 16 名、大腸 内視鏡と注腸透視 4 名、S 状結腸内視鏡と注 腸透視 1 名、S 状結腸内視鏡のみ 1 名、直腸 診または直腸鏡 2 名であった。

精密検査実施後の病名内訳は、大腸ポリー プ56名 (33名がポリペクトミーを実施)、大 腸款室 22 名、S 状結腸ポリープ 10 名、直腸 癌 1 名、結腸癌 4 名、痔核 25 名などであっ た。
今後、免疫学的便潜血反応柱定性検査加 定量検查に移行していくと推察される。それ によって、定性検查で境界線付近の值で正常 となっていた人たちにも注意を促し、疾患の 早期発見につなげることができると思われる。 また、定量値と疾患の相関性を検討し、効率 的なカットオフ值を考え直すことによって、 より有効なスクリーニング検査となると思わ れる。 
2D04門脈腫瘍栓合併肝細胞癌症例に対する治療の実態

田沢潤一 (タザワジュンイチ)
土浦協同病院内科
酒井義法・山根道雄・前田学

旰細胞癌・門脈腫癔栓・放射線治療

【緒言】肝細胞癌 (HCC) 進行例のなかでも 門脈本幹あるいは一次分枝に腫㾨栓を合併し た、いわゆるVp3肝細胞癌 (Vp3-HCC) 症例に 对しては、未だ確立した治療法はなく予後不 良である。Vp3-HCCに対してわれわれは、経 カテーテル的肝動脈化学塞栓療法 (TACE) 併 用放射線治療 (R-TACE) を主として行ってき た。門脈腫疼栓 (PVTT) の局所制御を放射線 体外照射により行い、肝内のHCCはTACEで治 療する方法である。今回、Vp3-HCC症例に対 する、当科における治療の害癿について检討

し、若干の考察を加え報告する。

【方法】1992年から1998年まで当科に入院し たVp3-HCC症例は44例であった。これらの内、 performance status 4 (5例) 、血清総ビリルビ $\nu 5 \mathrm{mg} / \mathrm{d} 1$ 以上（7例）、難治腹水 (2例) およ び全肝の50\%以上を占めるHCC (6例) の合計 20症例に関しては対症療法が行われた。これ らの除外基準に該当しない24症例に対し、文 書による説明と同意を得た上でR-TACEを施行 した。患者背景をChild-Pugh分類別にみると、 A 12例、B 8 例、C4例であった。最大のHCC の腫煬径では $5 \mathrm{~cm}$ 以上が 14 例だった。PVTTの 部位は、一次分枝までのもの16例、本幹に達 するもの8例であった。腹部CTおよび血管造影 によりHCCとPVTTの診断を確実にした後に、 まずTACEを施行した。さらに1から3週後に linearacceleratorを用いた体外照射を開始した。 照射目標のPVTTに 2 Gy の照射ができ、50\%以 上の非腫場部肝や、重要な周辺臓器への照射
を避けるために、必要に応じて多門照射を使 用した。照射スケジュールは1回あたり2Gy、 週5日で5週間、総量50Gyとした。

【結果】R-TACEにより半数例でPVTTに対する 局所効果が得られた。生命予後に寄与する因 子は多変量解析の結果、Child-Pugh分類と PVTTに对する局所効果のみであった。生存月 数は、PVTTに对する局所効果が得られた例で は2.8-37.1 (中央値9.7)、得られなかった例 では1.8-26.4(同3.8) で、PVTTを制御でき れはVp3-HCCの生命予淩を改善できることが 示された。PVTT制御に関連する因子について 多変量解析を行ったところ、Child-Pugh分類の みが抽出された。すなわち、Child-Pugh A症例 では、PVTTに对する局所効果が得られ易いこ とが判明した。併用療法により、発熱、嘔気、 咏吐や下癞が高穎度にみられたが、いずれも 対症療法で对応可能であった。

【考察】Vp3-HCC症例の治療戦略を以下のよ うに考えている。旰予備能が良くPVTTの切除 が可能であれは手術を選択する。しかし、 Child-Pugh Aではあるが、PVTTの切除が不能 の場合が大半である。このような場合が、 R-TACEの良い適応と考えられる。

【結論】Vp3-HCCといえども、TACE併用放射 線治療により半数例でPVTTに对する局所効果 が得られ、これらの症例では生命予後の改善 が認められた。とくにChild-Pugh A症例では、 高率にPVTTに対する局所効果が得られ、有用 な治療法と考えられる。 
2D05 総胆管結石の内視鏡治療における胆道内超音波検査の検討

後藤 寿則（ゴトウ トシノリ）

山本組合総合病院 消化器科

畠山 昇、坂下 佳子、熊谷 和久

総胆管結石、I DU S

【緒言】総胆管結石の治療は、経乳頭的内視鏡 治療が中心となってきているが、治療効果をあげ るためには結石の完全な排石が必要である。近 年、細径超音波プローブを用いた胆道内超音波 検査(Intra ductal ultra sonography;IDUS)が 膵胆道疾患に対しても応用されるようになり、今 回、遺残結石の診断に細径超音波プローブを用 いたIDUS の有用性について検討してみた。

【対象】総胆管結石にて、内視鏡的乳頭切開術 (Endoscopic sphincterotomy;EST)、採石術を 施行した12例である。

【方法】排石は EST 施行後、大きな結石の場合 は機械的破砕バスケット鉗子により砕石し、バス ケット鉗子、バルーンカテーテルを用いて排石し た。一週閔系 IDUS を施行し、IDUS の㨉入、率、 合併症について検㹬し逆行性内視鏡的胆道造影 (Endoscopic retrograde cholangiography ; ERC)との診断能を比較した。機種は、オリンパ ス社製の、ガイドワイヤ一誘導式細径超音波プロ ーブ(XUM-G20-29R)を使用した。

【結果】IDUS の㨂入率は100\%であ以、全例挿 入可能であった。合併症では、AMY の上昇が2 例 (16.7\%)に認められたが、腹痛は認められな かった。一週間後の遺残結石の診断では、ERC、 IDUS ともに遺残結石を認めない症例が4例 (33.3\%)、ERC では結石を認めず IDUSにて確 認できた症例が2例(16.7\%)みられた。それ以外 の症例は ERC、IDUS 共に結石を認めた。結石 の大きさは、ERC て確認できる大きさは $5 \mathrm{~mm} ま$

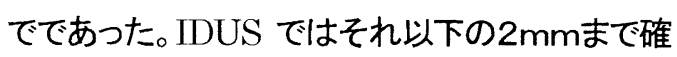
認可能であった。

【症例呈示】69才男性。上腹部痛を主訴に精査、 入院となる。超音波検査にて総胆管結石を認め、 経乳頭的に EST を施行した。結石は $10 \mathrm{~mm} 、 2$ Ommであり、当日採石を施行した。一週間後確 認 ERC を施行し、結石陰影を認めなかったが、 IDUS では3mmの結石を認め採石し、確認の IDUS でも結石を認めないのを確認した。

【考案】IDUS の挿入について、最近開発された ガイドワイヤ一誘導式細径超音波プローブを使用 することにより100\%挿入が可能であった。全例 EST を施行されているが、ガイドワイヤ一誘導式 を使用することにより、挿入時間の短縮がみられ またプローー゙の破損が一例志るられず、有男と考 えられた。総胆管結石の治療として内視鏡治療 は確立されてきたが、採石の確認としては、バル 一ンカテ一テル等により確認されてきたが、今回 $5 \mathrm{~mm}$ 以下の結石は ERC では確認できず、 IDUS にて確認可能であった。今回は全例 EST 症例であるが、内視鏡的乳頭拡張術 (Endoscopic papillary dilation;EPD) 症例では 小結石の診断が重要となり、DUS の必要性が 增してくると考えられた。 
2D06 手術が奏効した硬化性被囊性腹膜炎の一例

岐阜厚生連昭和病院 外科 福原政作 安藤修久 大池恵広 加藤裕 同内科 朝田啓明 小出滋久

\section{キーワード： 硬化性被囊性腹膜炎、CAPD}

硬化性被震性腹膜炎(Sclerosing encapsulating peritonitis : SEP)(持続的腹膜透析 (CAPD)における重篤な合併症の一つであ る。病態はびまん性に肥厚した腹膜の広範 な痹着による反復性あるいは持続性のイレ ウスであり、その成因は不明で、きわめて 予後不良の疾患である。今回われわれは外 科手術が奏効したSEPの一例を経験したの で報告する。

症例は 63 才男性。平成 4 年 4 月慢性腎炎 による慢性腎不全にてCAPD導入。その後 平成 6 年 3 月より平成 7 年 4 月の間に 4 回 の腹膜炎を発症したがいずれも抗生㓮投与 にて改善。平成 10 年 11 月より除水不良 のため血液透析導入。平成 11 年 1 月には CAPDカテーテル抜去した。その頃より腹 部膨満感、発熱、食思不振などが出現、血 液検査上炎症所見を認めたため抗生剤投与 するも改善認められなかった。同時期に施 行した腹部CTにて多量の腹水を認め、腹沿 穿刺にて無菌性、血性腹水であった。腹膜 生検施行し硬化性腹膜炎と診断された。

ステロイド剤投与開始するも症状改善無 く、黄㾝も出現してきたため保存的治療は 困難と判断し平成 11 年 7 月 14 日開腹下 癒着剥離術施行した。手術所見にては腸管 は白い糖衣様の被膜で覆われており一塊と なっていた。術後 12 日目より経口摄取開 始。その後黄㾝も改善し現在術後約 11 ケ 月経過しているが、外来血液透析にて全身 状態は良好である。 
2D07 進行膵癌に対する術中放射線照射（IORT)の効果の検討

谷川健次

鈴鹿中央総合病院外科

花村典子、池田 剛、飯田俊雄、中川俊一、今井俊積

膵癌、術中照射線照射、除痛

【目的】膵癌の予後は現在でも極めて不良 であり、特に進行膵癌では切除率も極めて 低く、切除し得た症例でも術後の疼痛に対 する治療に難啮することが多い。当科では 5 年前より、生存率及びQOLの向上を目指 して進行膵癌の手術の際には術中照射療法 （以下、IORT)を併施しており、今回、進 行膵癌に対するIORTの生存率改善や除痛の 効果などのQOL改善効果と検討した。

【方法】[対象] 過去10年間に経験した乳 頭部癌や粘液産生腫瘍をのぞく通常型の膵 癌で、手術時の進行度がTVa及び肝転移や 腹膜播種を伴わないIVb症例。IORT群（15 例）：膵頭部癌10例（バイパス術併施）、 体尾部癌5例（体尾部切除併施）、対照群

（15例）：IORT導入前の膵頭部癌10例(膵 頭十二指腸切除6例、バイパス術4例）、膵 体尾部癌5例（全例膵体尾部切除） [術中 照射］腹腔動脈および上晹間膜動脈の根部 を中心に30Gy照射、非切除例ではこれら に腫揚部存在部を追加した。

【結果】 [生存率］IORT群、対照群ともに 1年生存率は、切除の有無に関わらず20\% 以下で、bypass症例では2年生存するもの はなく、いずれの間にも有意差を認めなか つた。[生存期間］膵頭部癌IORT施行例で $297 \pm 140$ 日、膵体尾部癌IORT施行例で $315 \pm 122$ 日と対照群に比して生存期間が 延長する傾向が認められたが、統計学的に は有意差を認めなかった。[除痛率] IORT
群では術直後より疼痛が軽減または消失し、 除痛率は 80 から $90 \%$ で対照群に比して有意 に高率であった。またこの除痛効果は約 6 カ月間継続した。 [入院期間] IORT群では 対照群に比して短縮する傾向にあるが統計 学的には有意差は認められなかった。[在 宅率］パフォーマンスステータスが 0 ～症 例の状態の非入院期間の全入院期間に対す る割合を在宅率と定義した。IROT群の膵頭 部癌で在宅率は $68.7 \pm 12.3 \%$ 、体尾部癌で $76.2 \pm 8.5 \%$ と対照群に比して有意に高率 であった。［結語］1）進行膵癌に対して IORTは生存率の有意な改善は示さなかった。

2）腹痛や背部痛などの疼痛を有意に抑制 し、その効果は術後6力月後も継続した。3) 入院期間を短縮する傾向を示し、在宅率を 有意に改善した。以上より進行膵癌に対し てIORTは患者のQOL改善に有効であると 考えられた。 
$2 \mathrm{D} 08$ 甲状腺機能低下症を合併した門脈-体循環シがの1例

\section{大島 茂（おおしましげる） 北信総合病院内科 \\ 田尻和男、岡本隆一、清水まゆみ、山本力、社浦康三、 山岡一昭、牧下英夫、佐藤千史}

症例は 73 歳女性。高血圧、糖尿 病の既往。平成 6 年に歩行障害を認 め入院となり一過性脳虚血と診断。 平成11年 3 月から歩行障害、構音障 害を認め、脳梗塞との診断で再入院。 その後、後遺症もなく自立生活を送っ ていたが、平成 11 年 9 月 15 日朝昏睡 状態のところを家人に発見され入院 となった。入院時意識レベル $300 / \mathrm{JCS}$ で、脳幹梗塞を疑い治療を 開始した。しかし、画像診断上責任
門脈 - 体循環シャン、甲、状腺機能低 下症はともに代謝性脳障害の原因と なる。その両者の合併例はまれであ り、文献的考察を加え報告する。 病宩がはっきりせず、代謝性脳障 害の鑑別のため、血中アンモニア、 甲状腺ホルモンを測定したところ、 高アンモニア血症 (155 $\mu \mathrm{mol} / 1)$ 、 甲状腺機能低下症（T30.6 n g/ m l, T4 $3.8 \mu \mathrm{g} / \mathrm{dl}$, TSH $125.6 \mu$ $\mathrm{U} / \mathrm{m} 1$ l) を認めた。肝性脳症の治療 を開始したところ 3 日後には意識清 明となった。身体所見、血液検查上 は肝硬変は否定的であり、腹部 CT、 腹部血管造影上肝内門脈から下横隔 膜静脈への太いシャ恤管と下腸間膜 静脈から下大静脈へのシャ外血管を認 めたことから門脈 - 体循環シャ外を主 因とした意識障害と診断した。抗 サ仿がロブリ抗体 $92.5 \mathrm{U} / \mathrm{ml}$, 抗 $\mathrm{TPO}$ 抗体 $3.2 \mathrm{U} / \mathrm{m} 1$ であり甲状腺機 能低下の原因は橋本病と考えられた。 
2D09 肝特異性M R I 造影剂フェリデックスの使用経験-第二報-

MRI、Feridex、GRE法

丹羽政美 (にわ まさみ)
総合病院 養老中央病院放射線科 同部長 同院長 $^{\star \star}$
高木理光 平松 達 高橋尚宏 小野江雅之 安部威彦
近松克修 藤野明俊 仲田文昭 西脇伸二 西本虎正 $^{\star \star}$

\section{【はじめに】}

我々は第36回東海四県農村医学会にて0.5T MRI装置における肝特異性MRI造影剂フェリデ ックスの使用経験ならびに有効性を報告した。 しかし装置の進歩に伴い、高速撮像化が進みフ エリデックスを陰性造影剂のみならず陽性造影 剤として利用する報告も散在している。当院に おいても平成11年6月より装置の更新により高 速撮像が可能になったことより、グラジディエ ントエコー（GRE）法での至適条件を検討し、 文献的考察を加え、症例を含めてフェリデック スの有効性を報告する。

\section{【使用機器】}

使用装置はGE社製Signa MR/i echospeed 1.5T

Ver8.3 溶液ファントムは5 種類の(Feridex)混合 液 $(0.1,0.25,0.5,0.75,1.0 \mathrm{mmol})$

\section{【方法】}

1. 溶液ファントムを用いてFSPGR法にて撮像 した。TRは130msecに固定し、TEをminimamか ら12msecまで可変しファントムの信号強度を測 定した。

2. ボランティアによりTEを可変し、 contorast index 〔以下CI,CI=腫湟の信号值-肝藏の信号值/ 肝臓の信号值〕を測定した。

【結果】

1.溶液ファントムを用いた $\mathrm{T} 1$ 強調画像の至適 撮像条件はTE $2 \mathrm{msec}$ 以下であった。T $2 *$ 強調画 像の至適撮像条件はTE10msec以上であった。

2.ボランティアにおいてTE $2 \mathrm{msec}$ 以下におい て陽性造影剤としてTE $6 \mathrm{msec}$ 以上で陰性造影剤 として可能であった。

\section{【考察】}

フェリデックスは強力な $\mathrm{T} 2 \cdot \mathrm{T} 2$ *短縮効果の みならずGd系造影剤より強いT1短縮効果も有す るため、heavi 1yT1強調撮像を用いればフェリ デックスの集積した肝実質は高信号を示し、集 積のない腫湟は低信号を示すことが知られてい る。今回我々の検討でもファントム実験と同様 にボランティアにおいても TEが $2 \mathrm{msec}$ 以下の heavi lyT1強調撮像にて陽性造影剂として利用 可能であった。また、 $\mathrm{T} 2 *$ 強調画像の至適条件 はファントム実験ではTEが10msec以上であった が、ボランティアにおいては6msec以上であっ た。このことは、実際の臨床においてはフェリ デックスの取り込まれる量が違うため、肝臓と 腫瘍との磁化率の相違による差が考えれ、磁化 率の強いGRE法用いることによりファントム実 験より臨床において、より短いTEでT2*強調画 像が得られると考えられた。また、谷本らはフ エリデックス投与後50分以内にheavi 1yT1強調 撮像すれば肝血管腫は、血液プール効果により 肝藏よりも高信号になり、肝囊胞は中等度 $\mathrm{T} 1$ 強 調が含まれる $\mathrm{T} 2 *$ 強調撮像により消失し、肝腫 瘍との鑑別が可能であると報告している。

以上のことよりフェリデックスにおける撮像 は、従来のFSE法におけるT2強調画像に加え、 GRE法のheavi lyT1強調画像、中等度T1強調が 含まれるT2*強調撮像することにより、存在診 断のみならず質的診断も可能であると考えられ た。（肝細胞癌、肝転移の症例を呈示する。）

【まとめ】

今回我々は症例を含めフェリデックスの有効 性を報告した。 
2D10 肝エキノコックス症の治療経験

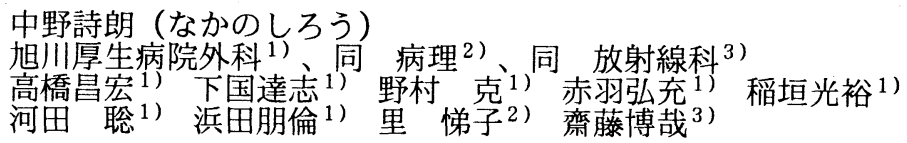

肝エキノコックス症、キッネ、肝切除

【背景】肝エキノコックス症は本邦では北海 道に特有の疾患であるが時に本州、主に東北 地方にも発症することがある肝疾患である。 検診体制が整備された近年では早期発見例 が多く、外科的切除で根治する症例がほとん どではあるが時に致死的となる症例もあり、 肝疾患の鑑別診断として特に北海道では重 要な疾患である。今回、過去 3 年間で当科で 外科的に切除した本疾患について検討した ので報告する。

【対象】1998 年 1 月から 2000 年 3 月まで に当科で外科切除した 6 例を対象とした (男 性 2 例、女性 4 例、平均年齢 57.7 才、 44 . 69 才）。上記症例の受診動機、職業、生活 歷、術前血清学的検査、画像診断、術式、予 後について検討した。

【結果】受診動機は 4 例が検診、2 例が他疾 患 (2 例とも胃癌) で検査中偶然発見された ものであった。職業は 4 例が農業従事者、 1 例が教師、 1 例が不明であった。飲料水は 1 例で井戸水を利用していた。術前血清学的診 断では ELISA 法、Westtern Blotting 法と もに全例陽性であった。画像診断では腹部超 音波検查、CT 検査で本疾患に特徵的とされ る石灰化を伴う多房性囊腫が 5 例 $(83 \%)$ に確認された。他の 1 例は CT で低濃度領域 として確認された。病変は全例多発しており、 2 病変 4 例、 3 病変 1 例、 4 病変 1 例であっ た。術式は肝右葉切除 2 例 (1 例幽門側胃切
除）、肝外側区切除 1 例、肝外側区切除+ S4,S6-7 部分切除 1 例（幽門側胃切除）、肝 部分切除 2 例（S5 部切、 $\mathrm{S} 5, \mathrm{~S} 6$ 部切）であ つた。病理組織所見では本疾患に特徵的なク チクラ層が全例に認められ、原頭節も 1 例 （17\%）に認められた。全例再発なく、生 存中である。

【考察】肝エキノコックス症は寄生虫である

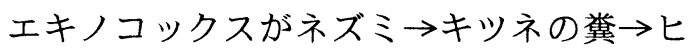
トの順に感染し、発症する良性の肝疾患であ る。キッネは家畜用の飼料を求めたり、家畜 そのものを襲うため、北海道のなかでも特に 農業従事者に発症することが多い(しかし、 現在では北海道全体が污染地域と言われて (る)。術前診断の血清診断で当科の症例が 全例、陽性であったことは本診断法の重要性 が再認識される結果となった。本疾患に対す る治療として経口駆虫薬であるアルベンダ ゾールなどが開発され、臨床でも使用されて いるが、外科切除で根治される例が多い。し かし、葉切除を必要とした症例はいずれも無 症状であったことから、早期に発見し、早期 に外科的に切除することが根治への早道と 考えられる。以前は発見が遅れ、肝不全から 死に至る症例も経験されており、より精度の 高い血清診断法の開発も含め、検診体制のさ らなる強化が重要と考えられた。 


\section{消化器疾患・肝・胆・膵 3}

2D11興味ある経過を示した大酒家肝障害の 2 症例

\section{福井実（ふくいみのる） \\ $\mathrm{JA}$ 北海道厚生連旭川厚生病院内科 \\ 成沢恒男}

限局性脂肪肝、禁酒

はじめに

今回飲酒によると思われる高度な脂肪 肝例および一過性の肝腫瘍椂陰影を呈し た限局性脂肪肝例を経験したので報告す る。

症例 $1: 41$ 歳 男性

生活歴 : 焼酎 4 合/日 約 25 年

黄疸を主訴に外来受診。ウイルスマーカ 一陰性。生化学検查で T.B $5.6 \mathrm{mg} / \mathrm{dl}, \mathrm{ALT}$ $130 \mathrm{IU} / 1, \mathrm{AST} 30 \mathrm{IU} / \mathrm{I}, \quad \gamma$ GTP $855 \mathrm{IU} / \mathrm{I}$ と高度肝機能異常を認めた為当内科入院 となった。腹部単純 CT 検査では、肝内に 辺縁不整の肝腫瘍椂の low density area(LDA)を認めた。ところが、入院に よる禁酒により、1 ケ月後の腹部単純 CT 検查では、肝内に多発していた LDA はすべ て消失していた。以上より、大酒家に生じ た一過性の限局性脂肪肝と診断した。

症例 2:54 歳 男性

生活歴：ビール 10 杯/日 約 20 年

黄㾝を主訴に外来受診。ウイルスマーカ 一陰性。生化学検查で T.B 10.0mg/dl, ALP1002IU/1, ALT 295 IU/l, AST $249 \mathrm{IU} / \mathrm{I}, \gamma$ GTP $3389 \mathrm{IU} / \mathrm{I}$ と高度肝機能 異常を認めた為当科入院となった。腹部単 純 CT 検査では、びまん性に CT 值が低下し 高度な脂肪肝が示唆された。入院による禁
酒により 10 日後の腹部単純 CT 検査では、 CT 值は改善し、その後肝機能は正常化し た。

考案 : 症例 1 の限局性脂肪肝は、アルコー ル多飲、糖尿病、肥満、ステロイド服用者 などにみられることがある 1,2)。原因は、 肝組織局所の低酸素状態 1)、不均一な肝 内血流分布によるインスリン濃度の不均 衡などがあげられている。経時的に LDA が 消失するのも特徵である。肝内占拠性病変 の鑑別疾患の一っに忘れてはならないと 考えられた。また 2 症例とも入院中での禁 酒により著名に改善していることから、断 酒会など、家族の協力を含めた日常生活に おける禁酒への指導の徹底さが必要と思 われた。

文献：

1)Clain JE et al:Ultrasonography and computed tomography in focal fatty Iiver-report of two cases with special emphasis on changing appearances over time-.Gastroenterology 87:948,1984

2)Gariballa SE et al: Case report-focal fatty liver infiltration causing mass effect-. Clin Radiol 52:630,1997 
シェーグレン症候群の経過中にみられたサイトメガロウイルス感染によると 思われる重症化した肝炎の1例

岸俊行（きしとしゆき）

香川県厚生連滝宮総合病院 内科

土田眞、大西誠、丸岡敬幸、渡辺一史、外山裕子、吉野すみ、鷹野護

一般にサイトメガロウイルス肝炎の場合、 トランスアミナーゼの上昇は 200〜300 まで にとどまる事が垑いとされているが、今回我 タは重症化したサイトメガロウイルス肝炎を 経験したので報告する。

症例泣 50 藏の女性です。主訴は全身倦息 感です。既往歴、家族歴に特記すべきことは ありません。現病歴愔昭和 60 年よりシェー グレン症候群及び尿細管性アシドーシスのた め当科通院中であった。平成 3 年 6 月より榶 疗病を合併し、平成 10 年 5 月からはインス リン治療を開始した。また、経過中、ステロ イドホルモンは短期間使用することはあった が、長期連用することはなく、肝障害につい ても、一度もみられなかった。経過良好であ ったが、平成 11 年 6 月初めより全身倦急感 が出現し、黄㾝を認め、精查加療目的で 6 月 3 日入院となった。腹痛や発熱はなかった。

現症では体格中等度で、栄養良好。眼瞼結 膜に筫血なく、眼球結膜に黄疸を認めた。表 在リンパ節は触れなかった。胸部に異常なく 、腹部で肝を 2 横指触知した。神経学的な異 常は認めなかった。

入院時検查所見では AST1079 IU/L、ALT $1192 \mathrm{IU} / \mathrm{L} 、 \gamma$-GTP 305IU/L、T-bili 8.69 $\mathrm{mg} / \mathrm{dl}$ 、抗核抗体 320 倍、抗 SS-A 抗体 $500 \mathrm{U} / \mathrm{ml}$ 以上、抗 SS-B 抗体 $336 \mathrm{U} / \mathrm{ml}$ 、 IgG $3052 \mathrm{mg} / \mathrm{d}$ 、HA-IgIM 抗体陰性、HBs 抗原陰性、HBc-IgM 抗体陰性、HCV-RNA 陰性、TTV-DNA 陰性、HGV-RNA 陰性、 EBV 関連执体陰性、HSV-IgM 陰性、 CMV-IgG(4+)、CMV-IgM(2+)、腹部エコ 一及び腹部 CT 検查では脾腫と腎石灰化を 認めた。

以上よりサイトメガロウイルスによる肝障 害が疑われた。入院後経過は特別な薬剂仙使 用せず、トランスアミナーゼの改善はやや遷 延しながら、7月 2 日にはALT 229 IU/L まで下降した。しかし、7月 26 日には 773 IU/ まで再上昇し、腹水もみられるようにな った。この時点でガンシクロビルを使用した ところ、8月 16 日には ALT 140IU/ となり、 全身状態も改善した。その後、肝機能異常は 正常化し、現在まで悪化はみられていない。

以上、シェーグレン症候群の経過中にみら れたサイトメガロウイルス感染によると思わ れる重症化した肝炎に対してガンシクロビル が有効であった 1 例を経験した。 
2D13 UFT内服によりAFPの著隇およひ肺転移巣の消失を恝めた肝細胞旊の一例

\author{
宮下一美（みやした かすみ） \\ 鉿麘中央数合病院内科 \\ 清水敦哉 西村晃 加藤正美 浜田正行
}

肝細胞蜎肺転移 UF T

症例は55才、男性。15才時に筫血にて輸 血を施行された既往あり。平成 7 年にC型慢 性活動性肝炎にてインターフェロン治療施 行されるも無効。平成 8 年にC型旰硬変と診 断。平成9年、肝 88 に HCCを琶めTAI施行。 平成10年6月、旰 $\mathrm{S} 6$ にCCCの再発を珰めた ためCTカイド下にPMCTを施行し、同部位 は十分な凝固壊死が得られた。しかしその 後もAFPの上昇が見られ、同年 12 月の腹部 CTにて肝S8にHCCの再発を琶め、更に胸部 CTにて多発性の肺転移巣が見られたため当 科入院。入院時、AFPは157.000 ng $/ \mathrm{m} 1$ にま で上昇していた。尚、PIVKA-IIは全経過を 通して正常䇢囲内であった。局所療法を断 念し、UFTの経口投与を開始。当初は血小板 が58000/ $\mathrm{mm}^{3}$ 、白血球が $1900 / \mathrm{mm}^{3}$ と低下 していたためUFTを300 mg より始め、その 後骨噵抑制・消化器症状等の副作用が見ら れなかったため $400 \mathrm{mg} に$ 增量。約 3 ケ月後に は、画像上原発单の $\mathrm{HCC}$ が直径 $7 \mathrm{~cm}$ から $4 \mathrm{~cm}$ に維小しAFPが1083ng/m1にまで減少し、 また肺転移巣が活は消失するといった著明 な効果を彗めた。HCCは外科的切除、TAE、 PEITなどの局所治源が有効な疾患だか、、肝 外転移や肝機能の面でこれらの治療の対象 とならない症例も少なくなく、現状では㟟 隔転移を伴うHCCの効果的な治療法はほと んど確立されていない。本例では、TAI PMCTを施行するもHCCの再発、またAFPの
著明な增加を認め、さらに多発性の肺転移 を琶めたため局所療法を断念し、UFTの経口 投与を開始した。当初は血小板が低下して いてため $300 \mathrm{mg}$ より始め、その後骨桠抑制 等の副作用が見られなかったため $400 \mathrm{mg}$ 增量し、原発巣の綟小およびAFPの隇少、ま た肺転移柴の消失といった著明な効果を認 めた。消化器渱に对する5-FUの一般的投与 量は300 $\mathrm{mg}$ から600 mgだが、高浱度の5-FU により肝硬変患者では肝機能が增黑し高率 に腹水や肝性脳症の発症をみたとの報告も あり、本症例でも $300 \mathrm{mg}$ から $400 \mathrm{~m} \mathrm{~g}$ の投与 にて肺転移笨の消失を認めたことより、肝 硬変合併肝癌に5-FU系薬削を投与する場合 は肝機能の增黑を考虑して少量投与から開 始すべきであると考えられる。HCCに对す るUFTの奏功率は20\%程度と低率であるが、 本例のような遠隔転移例に対してはUFTの投 与を試みる価値があると思われた。 
2D14 CT ガイド下経皮的マイクロ波疑固療法の治療経験

中村和義(なかむらかずよし)

1)放射線科 2) 外科 3) 内科

松下智人1) 今井俊積2) 中川俊一2) 谷川健次 2) 西村晃 3)

PMCT, CT, マイクロ波疑固療法

目的 : 経皮的マイクロウエーブ凝固療法 (PMCT)は US 下にて腫瘍と穿刺針が real timeでimage されるため通常US 下で施行さ れる。しかしながらエコーウインドウが狭く て腫瘍が image されない場合や腫瘍が深部に 存在する場合は穿刺針と誘導ラインのずれが 生じ施行困難である。我々は US 下にて PMCT 困難例を工夫を加え CT 下にて施行し その成績を述べる。

対象及び方法 : 1998.6.1 から 2000.6.30にて PMCT を施行した 15 例中の 6 例である。全 例男性で年齢は 48-71 歳 (平均 61)、S 状結腸 癌肝転移 2 例、肝癌 3 例、十二指腸癌肝転移 1 例である。腫瘍径は $13-30 \mathrm{~mm}$ で単発例 5 例、 多発 1 例である。

CT 下PMCTは8 回施行されCT下のみ 3 回、 CT と US 同時 3 回、CT とX線透視下 2 回で ある。CT下で穿刺する場合 CT で測定された 穿刺角度に正確に穿刺するために市販の分度 器と水隻器を接着して自作した。

結果: 症例 1,60 歳男性、単発肝癌例。US にて腫瑒は image されたが被膜下にあり右腎 と接して存在しているためUSにて穿刺しCT で確認しながら $60 \mathrm{~W}, 60$ 秒を三回施行した。施 行後 8 ヶ月にて再発は見られていない。

症例 $2 、 .61$ 歳男性、 $S$ 状結腸肝転移例。腫瘍 は肝S7 の梁部にあり IVC と接しているため 焼却ミスを防ぐためにまずUSにて穿刺しCT にて確認しながら $60 \mathrm{~W} ， 60$ 秒、 2 回にて焼却 した。残存が考えられため 2 回目はUS では
燒妁部と腫痬とが区別できず CT 下のみにて 腫瘍のわずかな石灰化を目標に穿刺し三回の 燒却を行った。施行後 4 ケ月にて再発は見ら れていない。

症例 3，.71 歳男性、S 状結腸幵転移例。US 下にて腫瘍は image されるが前症例と同じく S7 のIVCに接して存在した。 USにて穿刺時 呼吸停止がどうしても出来ないため穿刺針を 腫場に貫通出来ず二回の焼灼後 US 下にて近 傍に金属塞栓コイルを留置した。次回にこの コイルを目印に透視下にて穿刺し CT で確認 しながら二回焼却した。三ヶ月後の経過観察 でるが再発を認めていない。

症例 $4 ; 48$ 歳男性。肝癌例。US で腫瘍は同定 出来ないため血管造影時に近傍の動脈にマイ クロコイルを入れ CT-AP にて image された 腫瑒とコイルの関係を把握し、X線透視下に てコイルを眪に穿刺し CT で確認しながら 烓却した。6 年後にて再発は見られていない。 症例 $5: 55$ 歳、男性、肝癌例 US 下にて腫瘍 同定出来ずCT-APで見られた腫瘍を想定して CT 下にて穿刺した。二回の焼却にて同部の再 発は見られなかったが他部位の多発再発にて 15 ケ月後死亡した。

結語: CT は幾何学的精度が非常に良いため穿 刺針と腫瑝、周井の重要臟器との関係を正確 に把握しながら燒却でき重大な合併症は生じ 無かった。自作の角度計にて正確に穿刺出来 た。観察気管は短いが焼却部の再発例はな かった。 


\section{血液・アレルギー・内分泌疾患 1}

2D15 甲状腺乳頭癌症例の検討

高橋 学(たかはしまなぶ)札幌厚生病院外科、“同病理 近藤征文、岡田邦明、石津宽之、大沢昌平、益子博幸 西田靖仙、植林 隆、今井政人、渡邊值也、青木剛太 甲状腺乳頭癌、低分化型乳頭癌 長田忠大、“村岡俊二

【目的】甲状腺乳頭癌は通常緩徐な発育 を示しその予後は一般的に良好である。 しかし、低分化型乳頭癌は再発転移率が 高く予後が悪いと報告されている。そこ で甲状腺乳頭癌症例を高分化型と低分 化型に分け、その臨床病理学的特徵につ いて比較検討した。【対象】1993年より 1999 年までの 7 年間の甲状腺初回手術 症例を対象とした。【結果】初回手術症 例は 132 例で、乳頭癌は 57 例で甲状腺 悪性疾患の $87.7 \%$ 占めた。高分化型 乳頭癌(W 群)は 52 例(91.2\%)、低分化型 乳頭癌(P 群)は 5 例( $8.8 \%)$ であった。男 女比は、W 群で 1:3.73、P 群で 1:0.67 で P 群で男性の比率が高い傾向にあっ た。平均年齢は $\mathrm{W}$ 群で 51.8 歳、 $\mathrm{P}$ 群で 56.2 歳で差を認めなかった。平均腫瘍 径は $\mathrm{W}$ 群で $2.1 \mathrm{~cm} 、 \mathrm{P}$ 群で $3.1 \mathrm{~cm}$ で両 群間で有意差を認めなかった。リンパ節 転移はW 群で $77 \%$ 、P 群で $80 \%$ に認め 両群間に差を認めなかった。周囲臟器へ の浸潤は W 群 $19 \%$ 、P 群 $80 \%$ で P 群で 高率に周囲臟器への浸潤を認めた。遠隔 転移は $\mathrm{P}$ 群で $60 \%$ に同時性の肺転移を
認めたが、W 群では遠隔転移を認めな かった。手術術式は W 群で甲状腺全摘 9 例、带全摘 22 例、葉切除 21 例、 $\mathrm{P}$ 群 では全摘 3 例、亜全摘 1 例、葉切除 1 例であった。再発はW 群で 7 例(13.5\%) 認めたが、P 群では再発例はなかった。 予後については、両群とも原病死症例は なくW 群で最長 84 か月、 $\mathrm{P}$ 群で最長 40 か月生存中である。【結語】甲状腺低 分化型乳頭癌は高分化型と比較して周 囲臓器への浸潤および遠隔転移を高率 に認めたが、局所再発例は認めなかった。 また、低分化型乳頭癌症例で遠隔転移を 認めても 40 か月の生存例もあった。甲 状腺乳頭癌の手術では、低分化型および 高分化型ともに、局所再発なく良好な QOL を得るため局所の十分な切除、リ ンパ節郭清が必要であると考えられた。 


\title{
2D16 下垂体卒中の 2 例
}

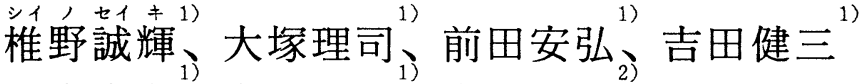 \\ 矢木文和、今川大仁、大野文俊 \\ 阿波病院 内科 徳島県農村健康管理センター
}

下垂体卒中、下垂体腺腫、M R I

【はじめに】下垂体卒中（PA）は下垂体腺 腫に合併することが多く、何らかの誘因によ り腺腫内出血や出血性梗塞が惹起され神経・ 内分泌症状が出現する。我々は臨床経過の異 なる下垂体卒中の 2 例を経験したので報告す る。

【症例】症例 1 : 63歳、男性。現病歴 : 平成 10年 6 月20日頭痛が出現、翌日当科を受診す る。鎮痛剤の投与にても症状改善せず、頭部 C Tは異常を認めなかったが、22日意識障害 が出現し入院となる。現症 : 身長 $162 \mathrm{~cm}$ 、体 重 $51 \mathrm{~kg}$ 、脈拍 $68 /$ 分、体温 $37.1^{\circ} \mathrm{C} 、$ 血圧 $120 / 70$ $\mathrm{mmHg}$ 。意識は傾眠様。脳神経系に異常なく、 運動、知覚障害なし。項部硬直は認めず。検 査成績と経過:白血球6,280/ $\mu 1$ 、CRP $0.7 \mathrm{mg} /$ dl、Naは $132 \mathrm{mEq} / 1$ と低値、髄液検査で細胞 数 $130 / 3$ 、蛋白 $62 \mathrm{mg} / \mathrm{d} 1$ と増加あり、中枢神経 系の感染症を疑ったが、24日MRIにて腫瘍 内出血を伴った下垂体腫瘍と診断した。hydrocortisone $100 \mathrm{mg}$ 注射後、意識障害、頭痛 とも速やかに改善した。内分泌検查では ACTH $8 \mathrm{pg} / \mathrm{m} \ell$ 、 cortisol $1.0 \mu \mathrm{g} / \mathrm{d}$ 以下、 $\mathrm{TSH} 0.06 \mu \mathrm{U} / \mathrm{m} \ell 、 \mathrm{FT}_{3} 2.5 \mathrm{pg} / \mathrm{m} \ell 、 \mathrm{FT}_{4} 0.6$ $\mathrm{ng} / \mathrm{dl}$ と低值で、GHは2.3ng/ml、PRLは2.6 $\mathrm{ng} / \mathrm{m} \ell$ 之正常。視野検査は異常を認めなかっ た。平成11年 1 月のMRIで腫瘍は著明に縮 小し、hydrocortisone $5 \mathrm{mg}$ 投与中であるが ACTH $15 \mathrm{pg} / \mathrm{m} \ell 、$ cortisol $25.6 \mu \mathrm{g} / \mathrm{dl} 、 \mathrm{TSH}$ $0.80 \mu \mathrm{U} / \mathrm{m} \ell 、 \mathrm{FT}_{3} 3.7 \mathrm{pg} / \mathrm{m} \ell$ となっている。 症例 2 : 68歳、女性。既往歴 : 平成10年 9 月
脳梗塞にて右片麻痺。現病歴 : 平成 11 年 6 月 10日歩行訓練中に左上肢の脱力、意識障害が 出現し入院となる。現症 : 身長 $132 \mathrm{~cm}$ 、体重 $46 \mathrm{~kg}$ 、脈拍 $98 /$ 分、体温 $36.6^{\circ} \mathrm{C}$ 、血圧 $190 / 102$ $\mathrm{mmHg}$ 。軽度の意識障害、構語障害あり。 右半身と左上肢に筋力低下、しびれ感を認め る。検査成績と経過 : 白血球 $6,540 / \mu 1$ 、血糖 $185 \mathrm{mg} / \mathrm{dl} 、 \mathrm{Na} 141 \mathrm{mEq} / 1$ であった。頭部CT で左被殼部に梗塞後変化。12病日MRIで下華 体部にT1強調画像で高信号領域がみられた。 内分泌検査はACTH $70 \mathrm{pg} / \mathrm{m} \ell$ と軽度上昇、 cortisol $10.7 \mu \mathrm{g} / \mathrm{dl} 、 \mathrm{TSH} 3.44 \mu \mathrm{U} / \mathrm{m} \ell 、 \mathrm{FT}_{3}$ $3.5 \mathrm{pg} / \mathrm{m} \ell 、 \mathrm{GH} 0.5 \mathrm{ng} / \mathrm{m} \ell 、 \mathrm{PRL} 6.4 \mathrm{ng} / \mathrm{m} \ell$ といずれも正常であり、無症候性の下垂体腺 腫内出血が疑われた。

【考察】下垂体卒中は腺腫内出血に伴い、頭 痛発作や視力・視野障害、意識障害、下垂体 ホルモン欠落症状などが出現する。典型的卒 中 (classical) から、無症候性 (subclinical) のものまで含めると、下垂体出血は全下垂体 腺腫の約 $10 \%$ にられるという報告もある。 卒中発作が腺腫発見の初発症状であることが 多く、症例 1 は、くも膜下出血や脳脊髄膜炎 を疑ったが、MRIでPAと診断することがで きた。症例 2 むRIで診断されsubclinical PAと考えられた。本症は早期診断が重要で あり、症例 1 では、ステロイドホルモン補充 により劇的な改善をみた。また、腺腫は縮小 し治癒傾向にあるがempty sellaへと移行す る例む報告されており経過観察が必要である。 


\author{
イトガ ユタカ \\ 系賀 寛 \\ 秋田組合総合病院 内科
}

Sweet病 ベーチエト病 紅斑

（はじめに）

Sweet病は、Sweetにより1964年独立した疾 患として提唱され、近年、悪性疾患（特に、 血液疾患）に伴う症例が多く報告さ秃てい る。今回、我々は、結節性紅斑を伴い、ヨー ドカリの単独投与により治癒せしめた症例と 耳下腺炎にひきつずき膿疮を伴う紅斑が多発 し、プレドニン内服で治癒した症例を経験し たので報告する。

（症例1）61歳女性。主訴：発熱、顔面、 下肢の皮疹。現病歴 : 平成11年8月13日より 高熱出没。8月14日某医院受診し治療を受け るも改善せず。その後、顔面、下肢に皮疹が 出現し、8月16日当科紹介され入院した。現 症 : 体温 $37.8^{\circ} \mathrm{C}$ 。右眼窩、両下肢に疼痛を伴 い、辺縁に小水疮を伴う紅斑を認めた。検查 成績: CRP24.0WBC14000 ESR81-122 と強い炎症所見を認めたが、針反応 : 陰性。 眼科所見：異常なし。右下肢紅斑の皮膚病理 組織学的所見：皮下脂肪織間に好中球、組織 球を主体とする細胞浸潤と、好中球の核破壊 を認めた。経過 : 以上よりSweet病と診断ヨ ードカリ 900mg/dayの経口とCMZ2g/day

DIVを開始したところ皮疹は速やかに消退 し、解熱した。

（症例2）37才男性。主訴：発熱、全身の 皮疹。現病歴：平成 11 年 12 月 13 日両耳下腺 腫脹あり、その後、高熱出没、全身に皮疹出 現。某医院受診し治療を受けるも改善せず、 12 月 16 日当科紹介され入院した。現症 : 体温 $39.0^{\circ} \mathrm{C}$ 。咽頭の発赤と両耳下腺の腫脹を認め た。また、全身に皮疹を認め、一部膿疮化し 下肢に著しかった。検査成績 : CRP7.8
WBC9800 ESR24-46 と炎症所見は軽度 であった。耳鼻科併診し耳下腺炎を指摘され る。針反応 : 陰性。眼科所見 : 異常なし、左 背部皮疹の病理組織学的所見: 皮下脂肪織間 にまで及ぶ好中球、組織球を主体とした細胞 浸潤と膿瘍形成を認めた。経過 : Sweet病と 診断。ヨードカリの経口投与するも改善な く、プレドニン $50 \mathrm{mg} /$ day の内服を開始し 皮疹消退、解熱した。

\section{(考案)}

Sweetや溝口が提唱したSweet病の診断基準 により、両症例とも必須項目と主要項目の 2 項目を満たし、症例1は典型的なSweet病の 皮疹であった。Sweet病は原因不明の炎症性 皮膚疾患で10-20\%に悪性腫瘍を合併すると 言われ、ベーチェト病との鑑別が問題である が、両症例とも口腔内アフ夕、眼症状は見ら れなかった。Sweet病はHLA-Bw54、ベー チェト病はHLA-B51との関与が指摘されて いるが、両症例とも認められなかった。両症 例とも治㾍後、Sweet病の再発を見ていない し、悪性疾患の発生も見ていない。 


\title{
2D18 高齢者慢性骨髄性白血病に対するインターフェロン療法
}

\author{
コベシトシ劢 \\ 小林敏貴、鴨下昌晴、川田健一 \\ (土浦協同病院内科)
}

高齢者、慢性骨髄性白血病、インターフェロン

【緒言】慢性骨鹃性白血病(chronic myelogenous leukemia : CML)では、骨酭 移植が治痹の望めるほほ唯一の治療法である が、合併症の多さなどから高齢者CML症例は 原則として適応にならない。Interferon(IFN) 療法は、Ph染色体の根絶も可能であり、この ような際には試みられるべきものである。今 回我々は、当院において経験した高龄者 CML のうち、IFNを用いた3例の経過を検討し、若 干の知見を得たのでここに報告する。

【症例】(1)67才女性。検診にてWBC增多を 指摘され1995年12月入院。WBC44200/ $\mu \mathrm{I}$ (Myel7, Stab5, Seg74, Ba9, Mo1, Lym4)、Hb12.3 g/dl、PIt108.5万/ $\mu$ I。 骨酭でPh染色体陽性。翌年1月17日より IFN600万U連日投与を開始、約1か月後には WBC、PItとも正常化した。12月より週3回 投与としたが、Ph染色体は徐々に減少、 2000年3月にはPh染色体陰性となった。 （2）67才男性。1998年7月WBC高值のため入 院。WBC114500/ $\mu$ I(BI1, Pro1, Myel1 4, Meta6, Stab4, Seg51, Eo5, Ba8, Mo5, Lym5)、Hb12.1 g/dl、PIt44.3万/ $\mu$ I。骨 賄でPh染色体陽性。27日よりIFN600万U連 日投与を開始、約10日でWBC、PItとも隇少 し始めたが、3週後には再びWBCが10万/ $\mu$ I を超え、さらに食欲不振、全身倦急感等もあ りIFNをhydroxyureaに変更した。その後一 時WBCは減少したが、1999年8月には再び WBCが增加し骨蹃性急性転化の診断となった。 化学療法を施行するも効なく10月死亡した。 （3）62才男性。偶然WBC增加を指摘され 1999年3月入院。WBC23430/ $\mu \mathrm{l}$ (Myel9, Meta3, Stab9, Seg56, Eo6, Ba3, Mo6, Lym8)、Hb14.8g/dl、Plt36.7万/ $\mu$ I。骨
賄でPh染色体陽性。17日よりIFN600万U連 日投与を開始したが、食欲不振、筋肉痛等の 不定愁訴が出現。10月より投与回数を漸滅し たが消失せず、2000年4月より週1回投与と した。WBC、PItとも現在正常上限程度であ るが、一時隇少傾向にあったPh染色体は再び 增加傾向にある。

【考察】CMLに対するIFN療法は、Ph染色体 の消失が7 9\%程度に認められるとされ、骨 髄移植が不可能な症例では第一選択といえる。 しかし、食欲不振、うつ、またHbやPItの過 度の滅少等があり、特に高龄者では長期投与 が困難な症例も少なくない。我々の症例では、 (1)は4年以上IFNを継続でき、Ph染色体は消 失した。一方(2)は、短期間の観察であった がIFNが無効なこと、および副作用から約 3 週 間で中止し 1 年後に急性転化となった。この 2 例の経過は、IFNは可能な限り長期間、隇量 なしの投与が効果的という既報告と合致する。 (3)は、不定愁訴的な種々の副作用からIFNの 投与量を漸滅したが、減少していたPh染色体 が再び増加傾向にある。このような症例では、 IFNを可能な限り隇量せず長期間投与するた めに、きめ細かな対症療法を積極的に行うこ とが非常に重要と考えられた。 
2D19 Major ABO 血液型不適合骨髄移植後に合併した赤芽球ろうの一例

鈴鹿中央総合病院内科 川上恵基、岡宏次

Major $\mathrm{ABO}$ 型不適合、赤芽球ろう，骨髄移植

【はじめに】Major $\mathrm{ABO}$ 血液型不適合の骨 䯣移植(BMT)に打いて合併した赤芽球ろう (PRCA)の一例を経験したので報告する。【症 例】 50 歳男性。平成 10 年 12 月診断の又 ントル細胞リンパ腫の第IV期。【経過】CHOP 等の化学療法に治療抵抗性であったため、 HLA 一致の兄より平成 11 年 7 月 23 日に BMT を行った。移植前処置は TBI $12 \mathrm{~Gy}$ と $\mathrm{L}-\mathrm{PAM}$ 。血液型は患者 $\mathrm{O}(+)$ 、ドナー $\mathrm{B}(+)$ の major $\mathrm{ABO}$ 型不適合の為 Cell Separator にて 単核球のみ分離し輸注。GVHD 予防は short MTX 及び CyA。血液学的回復は好中球数> $500 / \mu 1$ はday 17 , 血小板数 $>5$ 万/ $\mu 1$ は day 41 。 GVHD は grade I (皮膚のみ)。TMA(-)。9 月 2 日にサイトメガロウイルス感染併発するも DHPG にて回復。9 月 28 日、下腹部の単純 ヘルペス合併するもアシクロビルで回復。そ の他重篤な合併症はみられず完全寛解。しか し赤血球の回復は不良で移植直後より週一回 2 単位の $\mathrm{O}(+) \mathrm{LPRC}$ 輸血を要し、 day $80, \mathrm{Hb}$ $7.7 \mathrm{~g} / \mathrm{dl}$, 網状赤血球 $1 \%$ にて退院。退院後も リンパ腫は寛解を維持したが $\mathrm{Hb} 6.5-7.5 \mathrm{~g} / \mathrm{dl}$ を維持するのに同様のペースの輸血を要した。 また、退院後より慢性 GVHD の可能性のあ る軽度肝障害をみとめたので他の GVHD の 徵候はみられなかったが CyA は慎重に減量 し平成 12 年 5 月 10 日まで続けた。平成 1 1 年 11 月 4 日の骨髄穿刺を行ったところ PRCA の状態であった。抗 A,抗 B 凝集素価 は平成 11 年 9 月 13 日、平成 11 年 10
月 27 日及び平成 12 年 1 月 19 日いずれも 高值であった。これに対しステロイドパルス 療法等も考えたが、その後の免疫抑制状態か らの重篤な合併症を懸念し、デスフェラール の投与を併用し $\mathrm{O}(+) \mathrm{LPRC}$ 輸血と週一回 6000 単位のエリスロポイエチン製剂の投与のみ 行っていたところ平成 12 年 5 月 24 日突然 網状球が $29 \%$ と上昇しはじめ平成 12 年 7 月 6 日には輸血なしで $\mathrm{Hb} 12.9 \mathrm{~g} / \mathrm{dl}$ まで急激 に回復した。【考察】Major $\mathrm{ABO}$ 血液型不適 合 BMT における PRCA の原因は残存する患 者の抗 $\mathrm{A}, \mathrm{B}$ 抗体産生リンパ球由来及び輸血 血液製剂中の抗 $\mathrm{A}, \mathrm{B}$ 抗体がドナー赤芽球系 幹細胞を障害するためと考えられ、これに対 しステロイドパルス療法等の免疫抑制療法が 行われることがあるが、その後の免疫抑制状 態から重篤な合併症を引き起こす事も多い。 本例は、50歳と高龄であったことよりステ ロイドパルス療法は行わず、輸血で様子をみ ていたところ自然に PRCA の回復がみられ、 血液型もドナー型に転換した。Major $\mathrm{ABO}$ 血 液型不適合の BMT において合併した PRCA の治療時期の考虑において示唆にとむ症例で あったと思われた。 
$2 \mathrm{D} 20$ 当院における過去 10 年間の骨髄異形成症候群の臨床

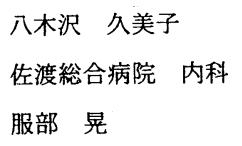

骨髄異形成症候群、染色体異常、白血病化

過去 10 年間に当院では、123 例の骨髄異形性 症候群（以下 MDS）を経験したのでその臨床 につき報告する。その内訳は、 refractory anemia(以下 RA) 97 例 $78.8 \%$ 、RAwith ringed sideroblast（以下 RARS） 8 例 $6.5 \%$ RAwith excess of blast（以下 RAEB）13 例 $10.5 \%$, RAEB in transformation(以下 -cytic leukemia(以下 CMMoL)2 例 1.6\%で あった。年齢別の患者分布では、70才女性が 多く 21 例で、次ぎに 70 才男性 19 例、60才女性 16 例であった.

初診時の血球減少であるが、0〜1系統が 48 例 39\%、2〜3系統が 75 例 61\%であつた。 赤血球系の減少が 104 例 $84.5 \%$ 、白血球系が 64 例 52\%、血小板系 70 例 56.9\%であった。初 診時骨髄所見では、過形成、正形成が 81 例、 低形成が 27 例であった。その時の染色体検査 では、90 検索例中 20 例異常が認められた。 一Y が 5 例、 $5 q$ 欠失が 3 例、9 逆位が 2 例で あった。

予後であるが、RAでは、AMLに移行した症例

が 1 例、RAEB に移行した症例が 1 例あった。 RAのまま骨髄不全になり死亡した症例が 7 例 7.2\%あった。RARS では、RAEB に移行し た症例が 1 例、RARS のまま骨髄不全となった 症例が 1 例あった。 RAEB では AML に移行した 症例が 3 例、RAEB のままであったが死亡した 症例が 3 例あり、いずれも RAEB 診断後 1 3 年であった。 RAEBinT では 3 例中 3 例が AML に移行した。CMMoLでは、2症例とも 8 か月、 10 か月で死亡した。 他の地区と比べると患者年令分布では、70才 女性が多い点がことなっていた。初診時赤血 球隇少は多く認められる所見であるが当院症 例においても $84.5 \%$ と高率であった。染色体 異常は 20 例に認められ-5 等の予後良好群が多 かった。RA が $78.8 \%$ と高く、他地区と異なっ ていた。RAの予後は一般的によいとされるが、 死亡症例も数例認められた。RAEB、 RAEBinT はこれまでの報告どうり高率に白血 病化した。 
2D21 当科における自己血輸血の実際

$\begin{array}{rrl}\text { O松田理 } & \text { 名越豊 } & \text { 加藤秀一 } \\ \text { 松岡宏明 } & \text { 稲田均 } & \text { 大萱稔 } \\ \text { 鈴鹿中央総合病院 } & \text { 整形外科 }\end{array}$

貯血式自己血輸血・術後回収式自己血輸血・人工関節置換術

【はじめに】慢性関節リウマチ（RA）、変 形性関節症 $(\mathrm{OA})$ に対して人工股関節置換 術（THA）、人工膝関節置換術（TKA）は 患者のQOLを改善するのに有効な治療であ る。しかし、術中、術後の出血が多くなり 同種血輸血を回避できないことがある。当 科では出血対策としてTHA、TKAを行う時 には積極的に自己血輸血を行っており、同 種血輸血による感染、移植片対宿主病の危 険から回避できるようにしている。今回当 科における自己血輸血について検討したの で報告をする。

【対象および方法】平成 5 年 4 月より平成 12 年 3 月までにTHA、TKAのため自己血 輸血を行った164例である。男性19例、女 性145例、年齢は31歳から86歳で平均 64.8 歳であった。疾患はRA84例、OA77例、そ の他3例であり、手術はTHA75例、TKA89 例、そのうちセメント使用例は5例であっ た。自己血輸血として貯血式と術後回収式 を併用した。セメント使用例は術後回収式 は行わなかった。

【結果】全例貯血式自己血輸血を行い、平

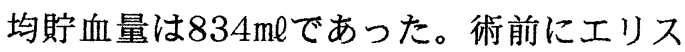
ロポエチン（rEPO）を使用し、鉄剤の投与 も行った。自己血貯血中に副作用で貯血を 中止した症例はなかったが、貯血量が $500 \mathrm{ml}$ となった症例があった。術後回収式 自己血輸血は非洗净式で術後 6 時間以内に

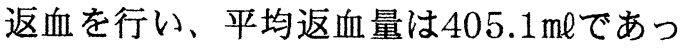
た。返血中に副作用を起こした症例はな かった。しかし回収システムの不備や凝血 によって返血ができなかった症例が9例みら れた。同種血輸血は術後164例中6例に施行
され、同種血輸血回避率は $96.3 \%$ あった。 そのうち2例はセメント使用例、2例は両側 TKA例、残りの2例はRAであった。

【考察】自己血輸血は整形外科だけでなく 心臓血管外科、泌尿器科、消化器外科など の待機手術に用いられ、同種血輸血回避を 目的として最近重要視されてきている。今 回我々は人工関節置換術において、積極的 に自己血輸血を行い同種血輸血を回避する ようにしてきた。その結果、同種血輸血回 避率は $96.3 \%$ あった。同種血輸血が行われ た症例を検討すると、6 例とも貯血式では $800 \mathrm{ml}$ もくは $900 \mathrm{~m}$ 採血され術中および術 後に自己血輸血が行われていた。しかし、 (1)セメント使用の 2 例とRAの 1 例は術後回 収式が用いられなかったこと、(2)両側TKA の 2 例は術中、術後の出血が多かったこ と、(3)RAの 2 例はrEPO使用にもかかわら ず術前へモグロビンが低値となっていたこ と、などがあり、これらの理由で術後同種 血輸血が必要となったと考えられた。当科 では、RA患者に対する手術が多く、また術 後の出血が多いTKAを行うことも多いた め、今後も貯血式と術後回収式を併用して いき、同種血輸血から回避できるょうにし て行きたいと思っている。

【結語】待機手術においては、自己血輸血 を行うことは同種血輸血回避に有用である と考えられ、また、貯血式と術後回収式を 併用することでさらに回避率をあげること ができると考えられた。 
$2 \mathrm{D} 22$ 尿中 $H$ e $I$ i $c$ o b a c t e $r$ pylor $i$ 抗体測定法の検討

木田秀幸（きだ ひでゆき）・飯田健一

札幌厚生病院臨床検查技術部門

杤原正博・今村哲理 札幌厚生病院第一消化器科

非侵襲検査・陽性率・一致率

<緒言>Helicobacter pylori (以下HP) は 胃内に棲息するグラム陰性のらせん桿菌であ り、消化性潰瘍や胃炎、胃癌、胃MAL T リ ンハ腫の発生に関与しているといわれている。 感染の有無を確認する検査法としては、生検 胃粘膜を材料とする細菌培養、病理組織学的 検査、迅速ウレアーゼ試験、PCR法や血清 等を材料とする抗 $\mathrm{H} P$ 抗体測定法があるが初 期診断、集団検診などのスクリーニング検査 や除菌後の経過観察を考慮すると精度が良く、 簡便にH P 感染の有無を検出できる方法が望 まれる。そこで、非侵襲的に検査が可能な尿 中抗HP抗体検出用試薬の検討を行なった。 <使用試薬及び測定原理 $>$ 尿中抗H P 抗体検 出用試薬『ウリネリザH. ピロリ抗体』(大塚 製薬社）:OHPC-O 40 （日本人臨床分離 株）抗原を固相化したE I Aプレート法。ま た、対象として血清中抗 $\mathrm{P}$ P抗体検出用試薬 『デタミナーH. p y l o r i 抗体』(協和义 デックス社) $\mathrm{HM} ・ \mathrm{CAP}$ 抗原を用いたE I Aプレート法、ペプシノーゲン (以下PG)

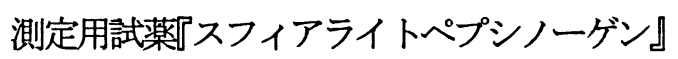
(和光純薬社) 分析器スフィアライト 180 (オリンパス社) にて測定する免疫化学発光 法を用いた。

〈対象と方法>当院人間ドック受診者 221 名（男性123名、女性98名）を対象とし 受診時の新鮮尿を用いて尿中抗 $\mathrm{HP}$ 抗体を測 定し計算式よりカットオフインデックス（以 下C I）を求めC I = 1.00 以上を陽性とし

た。血清中抗HP抗体は、検量線よりC I を 求め 2.3 以上を陽性とした。PGは、PGI、 PG II 測定LPG I 7 O以下、PG I ・II 比 3.0 以下を陽性とした。また、胃バリウム 検査判定結果との関連を調べた。

<結果>尿HP抗体陽性者は、132名で陽 性率 $59.7 \%$ （男性74名6 $0.2 \%$ 、女性 5 9.2\%) であった。血清抗HP抗体との一致 率は、8 $7.1 \%$ であった。不一致例 17 例は 全て尿陽性、血清陰性でありそのうち 7 例が 尿潜血 (+) による偽陽性、 1 例が尿蛋白 (+) による偽陽性であった。偽陽性例を除いた一 致率は、92.7\%と高い一致率を示した。年 代別では、60歳代、70歳代で高い陽性率 が示された。PG陽性者との一致率は41. $9 \%$ であったが P G 陽性者のうち $96.2 \%$ が尿HP抗体陽性であった。胃バリウム検査 判定において胃、十二指腸潰場及び殷痕と判 定された受診者の陽性率が有意に高かった。 <考察>尿中抗H P抗体測定は、尿潜血、尿 蛋白での偽陽性反応が見られるもののHP検 出率が高いとされている血清中抗HP抗体と の一致率も高く非侵襲的で検体採取が容易で あり被検者の苦痛を伴わないため初期診断、 集団検診などのスクリーニング検査に有用性 が高いと思われる。また、除菌成功例では、 抗体が陰性化するといわれているため除菌後 の経過観察にも有用性が高いと思われる。

(尚、本研究は、日本農村医学研究会の助成 物件によるものである。) 
2D23

\section{ラテックス凝集法による $\mathrm{HbA1c}$ 測定の検討}

マエダ キヨシ

前田 清

愛知県厚生連長久手農村健診センター

本田 哲男、高木 真澄、古田 和彦、神谷 正行

四方 治、山田 晴生

(key ward)HbA1cＨPLCラテックス凝集法

[目的］従来より $\mathrm{HbA} 1 \mathrm{c}$ は、高速液体ク ロマトグラフィー法 (HPLC) が日常検 查として一般的でありましたが、最近で は免疫比濁法等の汎用試薬が開発され、 普及してきたようである。

今回、生化学分析装置で検査が可能な、 ラテックス凝集法による、HbA1c 測定 試薬（ラピディアオート HbAlc：富士 レピオ）について HPLC との比較を検討 したので報告します。

[対象・方法] 検查対象として当健診セ ンタ一受診者 235 名 (1) と糖尿病患者検 体（病院通院検体）99 名 (2)合計 334 名 とした。

測定機器は東芝 TBA80FR-NEO を 使用し、比較検象機器は、(1)を当センタ 一HPLC (京都第一化学)、 (2)を安城更 生病院 HPLC（東ソー）で比較した。

検体は、採血後一晚放置または 2000 $\mathrm{rpm}$ で 2 分間遠心分離後沈殿した 血球 部分 $10 \mu$ 1を検体希釈液 $100 \mu 1$ で溶血 させ測定検体とした。

本キットは、検体中の $\mathrm{HbA} 1 \mathrm{c}$ をラテッ クス粒子表面に吸着させこれに抗 $\mathrm{HbA1c}$ マウスモノクローナル抗体を反 応させる。この時に生じるラテックス凝 集を濁度として波長 $660 \mathrm{~nm}$ で測定し、 全血中の HbA1c（\%）を算出する。

[結果］I：HPLCとの相関

(1) HPLC 法「京都第一化学」 $\mathrm{n}=235 、 \mathrm{r}=0.893 \quad \mathrm{y}=0.858 \mathrm{X}+0.573$

(2) HPLC 法「東ソー」 $\mathrm{n}=99, \mathrm{r}=0.953 \quad \mathrm{y}=0.871 \mathrm{X}+0.510$
(3) 全 HPLC 法

$$
\mathrm{n}=334, \mathrm{r}=0.978 \quad \mathrm{y}=0.870 \mathrm{X}+0.513
$$

II : 診断効率等の比較

血糖値： $126 \mathrm{mg} / \mathrm{d} 1$ 以上 $\mathrm{HbA} 1 \mathrm{c} 6.5 \%$ 以上を糖尿病として線引きしました。（当 センター健診基準)

$$
\mathrm{n}=334 \text { 名 }
$$

診断感度 $=96.6 \%$

診断特異度 $=93.1 \%$

診断特異性 $=94.0 \%$

[考察]今回の検討により、HPLCに対 して良好な相関であった。

また、診断感度・診断特異度・診断特 異性も良好な結果が得られた。

しかし HPLC 2 社と本法の差が僅か に認められたが日常検査時において判定 に影響を与えるほどの差ではない為、本 キットによる日常検查及び健診検査での 多数迅速処理が可能であると思われる。

病院の糖尿病患者 HbA1c においては 治療中の検体で一時的に基準値以内の值 に落ちているものが数件あったので、害 際の診断感度等の結果は下がると思われ るが、HPLC・ラテックス法ともに值の 差が少なかったことをみると、検查值上 での問題は無いと考える。

[まとめ] 本キットは、汎用試薬でもあ り、各社生化学分析装置での測定が可能 なことから、当センターのように、1 日 の処理数が多い施設ではHPLCと比べ処 理時間の短縮が可能で、また測定機器も 新たに必要としない為、費用効率の面で も効果を得られるであろう。 
2D24 リウマチ因子検查における従来法と抗ガラクトース欠損 I g G 抗体測定の比較検討 ペロょゅれ

別所裕二 原ひろみ笠井みどり 井上みほ 高士裕美 瀬川善樹 村田哲也

(三重厚生連鈴鹿中央総合病院 中央検查科)

抗ガラクトース欠損 I g G 抗体 セロネガティブRA＼cjkstart慢性関節リウマチ

【はじめに】現在、慢性関節リウマチ（R A）のスクリーニング検査としてCR P、 E S R、リウマチ因子などが用いられてお り、中でもリウマチ因子（RF）は他の検 查法に比べ特異性が高く慢性関節リウマチ の診断に有用である。しかし慢性関節リウ マチ患者の約 30\%はリウマチ因子陰性 (セ ロネガティブRA）である。これは従来の リウマチ因子検查法 ( T I A ・ R A P A) が I g M型リウマチ因子のみを測定してお り、他のグロブリンクラスのリウマチ因子 を検出できなかったためである。近年 $\mathrm{R}$ A患者は健常人に比べ血清中 I g Gのガラ クトースが顕著に隇少していることがわか り、このガラクトース欠損 I g Gに対する 自己抗体、抗ガラクトース欠損 I g G抗体

（RF）を測定できるようになった。この 抗ガラクトース欠損 I g G 抗体測定ではす べてのグロブリンクラスのリウマチ因子を 検出できるため、従来法に比べより高感度 な検出が可能となった。そこで、患者血清 中の抗ガラクトース欠損 I g G抗体を測定 し従来法（T I A ・ R A P A）との相関に つい険討したので報告する。

【方法】当院外来初期リウマチ患者 46 名 において抗ガラクトース欠損 I g G 抗体 (定性・定量) とRF（T I A ・ R A P A ) を測定した。

【結果】対象 46 名におけるリウマチ因子 の陽性率は次の通りであった。

\begin{tabular}{|l|c|c|}
\hline \multicolumn{1}{|c|}{ 方法 } & 陽性者数 & 陽性率 \\
\hline $\mathrm{RF}$ (TIA) & 10 & $21.7 \%$ \\
\hline RAPA & 29 & $63.0 \%$ \\
\hline * (定性) & 38 & $82.6 \%$ \\
\hline * (定量) & 36 & $78.2 \%$ \\
\hline
\end{tabular}

\begin{tabular}{|c|c|c|c|}
\hline & $\mathrm{RAPA}(+)$ & $\mathrm{RAPA}(-)$ & 計 \\
\hline$*(+)$ & 29 & 9 & 38 \\
\hline$*(-)$ & 0 & 8 & 8 \\
\hline 計 & 29 & 17 & 46 \\
\hline
\end{tabular}

*は抗ガラクトース欠損 I g G 抗体を表す。

セロネガティブRA患者 1 7名中における抗 ガラクトース欠損 I g G抗体晹性率 $52.9 \%$

【考察】対象 4 6名すべてが慢性関節リウマ チと診断されているのにもかかわらずR F

（T I A ・ R A P A） は結果の通り低い陽性 率であった。逆に抗ガラクトース欠損 I g G 抗体は約 $80 \%$ と高い陽性率であり、従来法 に比べ優れた検出率であるといえる。また、 セロネガティブR A患者は他のグロブリンク ラスリウマチ因子の存在が疑われ、従来法で は見落とされていたリウマチ因子が検出され たものと考えられる。

【まとめ】慢性関節リウマチでは、早期䛦断、 早期治療が必要不可欠であり、初期段階での 確実なスクリーニングが重要となってくる。 この抗ガラクトース欠損 I g G 抗体は感度、 特異性に優れており慢性関節リウマチの診断 に大変有用であると考えられる。 


\section{感染症 - 細菌感染}

2D25当院小児科における感染性下痢症の病原体に関する研究

牛垣黃由美 中根一匡 舟橋恵二 田中克己 宮川 恵子* 細野治樹* 竹本 康二* 秋元 史帆* 丸地明子* 西村 直子* 尾䗁 隆男* 愛知県厚生連昭和病院 臨床検查科 *同小児科

サルモネラ

ロタウイルス

【緒言】感染性下脷症は小児期感染症として 非常に頻度の高い疾患であり、その起因病原 体はウイルスと細菌に大別される。乳幼児で は主にウイルス性下湖症であり、年長児にな るにつれて細菌性下浰症が増加してくる。ま た、流行の季節性や局地的な集団発生があり、 その動向を把挃することは重要である。

今回我々は、当院小児科に打汀感染性下 痢症の病原体を検討し、さらにサルモネラに ついては薬戍感受性も調查したので報告する。

【対象と方法】1999 年4月２000 年3月 の 1 年間に、当院小児科に下峲を主訴として 受診した患児の便または直腸スワブから、起 因病原体の検出を試みた。ロタウイルスはロ タレックスドライ(第一化学)、アデノウイル スはアデノレックスドライ(第一化学)のラテ ックス凝集反応法を用いて行った。サルモネ ラおよび病原性大腸菌は DHL 寒天培地(栄 研)、カンピロバクターはスキロー改良培地 (栄研)、黄色ブドウ球菌はマンニット食塩培 地(栄研)を用いて分離した。また、サルモネ ラはパイルチューブ No.1(栄研)を用いて同 定し、サルモネラ免疫血清 1 号(デンカ生研) により、O 抗原の型別を調查した。サルモ ネラの薬郕感受性は、ABPC、CTX、PAPM、 LMOX $、 C Z O P 、 C M Z 、 C D T R 、 C P D X 、 C C L 、$ LVFX、MINO、FOM 12 種類の抗菌薬につ いて、微量液体希釈法(日本化学療法学会標 準法)によりMICを测定して検討した。

【結果および考察】ロタウイルス、アデノウ
イルス、サルモネラ、カンピロバクター、黄 色ブドウ球菌および病原性大晹菌が検出され た患者数を集計し、その月別発生状洗を検討 した(表)。ロタウイルスは 3 月が 43 例と最 も多く、5〜7月においても 9 例が検出さ れた。冬期流行型といわれるロタウイルスだ が、以前の報告と異なり春から夏にかけても 検出された。アデノウイルスは 8 月が 5 例と 最も多く、11 3 月の冬期には計 3 例と少 数であった。カンピロバクターは 7 月に 8 株 と最も多く分離されたが、その他の月に大き な偏りはなかった。サルモネラは春から夏が 分離の中心であった。現在わが国におけるサ ルモネラ分離株は、S. enteritidis (O9)が最も 多いとされている。今回の成績でも、09群(11 株)は、イカ菓子によるサルモネラ腸炎の流 行の起因株であったS. oranienburg (07:14 株)に次いで分離されていた。黄色ブドウ球 菌は年間を通して分離され、病原性大腸菌は 6月に 1 株のみ分離されたが、VT産生株で はなかった。

サルモネラの薬剤感受性は、NCCLSの勧告 による分類で、33 株中 ABPC 耐性が 1 株、 MINO 耐性が 5 株であり、他の薬郕に対し ては全株が感受性を示した。

\begin{tabular}{|c|c|c|c|c|c|c|c|c|c|c|c|c|c|}
\hline & 月.11.4月 & 5月 & 6月 & 7月 & 8月 & 9月 & 10月 & 11月 & 12月 & 12.1 月 & 2月. & 3 月 & Ht \\
\hline Rotavinus & 22 & 3 & 3 & 3 & 0 & 0 & 0 & 2 & 3 & 7 & 21 & 43 & 107 \\
\hline Adenovirus & 1 & 1 & 3 & 1 & 5 & 1 & 0 & 0 & 1 & 0 & 0 & 0 & 13 \\
\hline Salmonella & 10 & 2 & 1 & 5 & 4 & 4 & 4 & 0 & 0 & 1 & 1 & 1 & 33 \\
\hline Campyibobacter & 1 & 2 & 3 & 8 & 5 & 2 & 6 & 1 & 5 & 1 & 3 & 2 & 39 \\
\hline S.aureus & 2 & 7 & 5 & 0 & 4 & 2 & 2 & 3 & 1 & 4 & 3 & 0 & 33 \\
\hline E.coli & 0 & 0 & 1 & 0 & 0 & 0 & 0 & 0 & 0 & 0 & 0 & 0 & 1 \\
\hline
\end{tabular}


2D26 抗菌予防着と一般予防着における MRSA 付着率の比較検討

\section{三浦 薫 (ミウラ カオル)}

愛知県厚生農業協同組合連合会更生病院

白井敦子・喜納美津代 - 稲垣慎子・渡辺篤

抗菌予防着・MRSA

くはじやく

近年口常生活における清潔志向の高まりと ともに数々の抗菌加工製品が販売され、医療 分野での製品も開発されている。

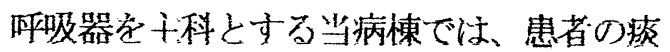
からの MRSA 発生件数が多く、看護嗄の予 防着からも高頻度に確認されている。

そこで、抗囷作用のある䂆防着に着目し、院 内感染を減少させれ代と考えた。

$<$ 日的 $>$

抗菌预着之一般䂆方着の MRSA 検出率在 比㜞し、抗菌の有效性在娭討する。

<対象>

2-2 看護婦 16 名

$<$ 期間>

平成1 1 年 4 月 6 日 平战 11 年 9 月 24 日 <症例数 $>323$ 件

$<$ 方法 $>$

1）抗菌予防着着用者、一般䂆方着着用者を 8名ずつに分け、3ケ月で交藐した。

2）予防着交換表を作成し、白衣交換した日 时を各自記入してもらった。

3）菌採取日は、毎週金曜日、午後 4 時とし t。

4）菌の対象はMRSAとした。

5) 採取部们は、昨件 $の$ 仾究結果上り MRSA 恰出が最も多かった胸腹部 1 ケ所とし た。

6）培養法は、バイオ air チェッカー法とし t.
$<$ 若察 $>$

今回私達の研究結果では、抗菌予防着群之一 般予防着群莸比較検封して老、有 意差はなかった。その要因として

1）抗菌作用はあるかもしれないが、病㤓ス タッフは常に患者に按している為、新た な菌の付着が絶えず起こる叮能性があ 万。

2）予防着を掛けている間に、菌の利着や落 下の可能性がある。

3）抗菌加工法の種類によっても劫果に兴 がある。

くまとめ>

- 抗菌の有效性を知る目的で、抗菌予防着上 一般预防着のMRSA検出率至比較検討した。 その結果 MRSA 発牛件数、菌数に有意差は みられなかった。

・抗菌製品に頼るのではなく、効果的な環境 整㦈、手洗い力法の娭討が必要である。 
$2 \mathrm{D} 27$ 本邦初のバンコマイシン而性腸球菌(VRE)アウトブレークの検討と危険因子の解析

$$
\begin{aligned}
& \text { 新 謙一（あたらしけんいち） } \\
& \text { 北信総合病院 内科・感染対策委員会 } \\
& \text { 馬場浩介, 藤木協子, 高元俊彦, 社浦康三, 西村博行 }
\end{aligned}
$$

VRE，アウトブレーク，危険因子

【背景】欧米ではVREが院内感染の $1 / 4$ を 占めるほど急増している。本邦でも 1996 年 以降VRE症例が散見され、更に輸入鷄肉の VRE污染が示されるなど、近い将来のVRE の蔓延が専門家の間で予測されていた。 VREは所謂「感染症新法」では第4類の全 数報告に指定され、感染症週報で実数が公 表されている。この様な状況で1999年夏に 当院では本邦初のVREアウトブレークを経 験したが、必ずしも実状を正しく報道され ていない印象がある。そこで、VREに関す る我々の知見が広く正しく認識されること が、VRE曼延に対抗する一つの手段になる と信じてここに報告する。

【目的】当院で認めたVRE症例を細菌学的・ 臨床的に検討し、アウトブレークに焦点を 当て感染対策で重視すべき危険因子を明ら かにする。又、その後の感染対策の効果に ついても紹介する。

【方法】1999年7月から当院で経験した VRE(MIC $16 \mu \mathrm{g} / \mathrm{m}$ lを含む) 陽性 24 症例に 対しPCR・パルスフィールドゲル電気泳 動法 (以下PFGE) 等にて細菌学的特徵を検討し、 臨床的特徵を評価した。

【結果】VREは全てVanB型のE.faecalis で PFGEで2つのstrainが確認された。殆どの 症例はおむつ排泄の寝たきりの高秢者であつ た。原疾患が悪性腫瘍など難治性の疾患の 場合は死亡の転帰を示したが、VREが直接 死因と確認できた症例はなかった。最終的 に感染と考えられた 3 例のVREに由来する
症状は極めて軽微であった。残りの症例は 全て単なる保菌に留まり、経過中特に治療 をせずに消失する症例も少なからず認めた。 患者は同じ階の内科系 2 病棟に関与してい た。ロジスティック重回帰分析（変数減少 法; 尤度比) では VCM 使用 (OR 35.1; 95\%CI 1.4-880)、おむつ使用 $(32.2$; 3.5-298)およびモノバクタム/カルバペネ 厶系抗生剂使用 $(5.3 ; 1.1-24.6)$ が危険因子 であったが、VRE判明前の同室歷は有意な 危険因子ではなかった。

一方で当院の入院歷がなく他院入院後老 人保健施設を経由してきた症例の入院時の 検査でVREが陽性になった症例もあった。 本例は当院のVRE症例との接触も全くない にも拘わらず、アウトブレーク株と同一菌 であった。

【総括】今回のVRE感染は院内感染のみな らず、地域に複数のVREが潜在している可 能性を初めて示した教訓的事例である。我々 の経験したVREは通常経験するMRSAと異 なり病原性が極めて弱く、積極的に検体を 提出してスクリーニングしない限り見過ご される可能性が極めて高い。一方で定着が 極めて早い印象も拭いきれない。今後は日 本のコミュニティーにも既に VREが存在 していることを意識して、危険因子に基づ いた易感染者に重点を置いてVREを早期検 出すること、普遍的予防措置および感染経 路別予防措置を更に徹底することが急務で ある。 


\section{感染対策}

2D28 ベッドウォッシャーにおけける細菌学的污染除去効果の検討

笩部晃司

広島県農村医学研究所 (厚生連廣島総合病院 臨床研究検查科)

白井和媄 林旧静枝. 白石幸雄 関口善孝

院内感染、ベッドウォッジャー、環境清浄

\section{【はじめに】}

現在、あらゆる医療機関で院内感染は深刻な 問題とされているが、その解決は難しく苦慮し ているのが現状である。院内感染防止対策と しては、消毒剤や殺菌剤はもちろんであるが、 その他に環境清净の維持も重要であるといえ る。そこで当院では環境の清浄度維持管理を 目的としたベッドウォシジー一導入したので、 その洗浄・消毒効果についてベッド本体・マッ トレス(蒸気・温水)を条件別で検討した。

\section{【対象と方法】}

(1)試験菌液:下記 4 菌種を馬脱繊維素血液に 混釈して $10^{8} / \mathrm{ml}$ 濃度に調整した 菌液を試験菌液とした。

\section{MRSA·P.aeruginosa (緑膿菌)}

E.faecium (腸球菌) - B.subtitis (枯草菌)

(2)試験負荷:

・洗浄、乾熱滅菌したステンレス金属片 $(1 \times$ $1 \times 13 \mathrm{~cm})$ の一面に試験菌液を $0.1 \mathrm{ml}$ 叙布し、 24時間室温放置して乾燥させたものを使用

・マットレス片 $(1 \times 1 \times 1 \mathrm{~cm})$ を乾熱滅菌し、試 験菌液を付着させ、24時間室温放置して乾 燥させたものを使用

(3) 条件設定

ベッドウォツシングディスインフェクション （温水洗浄除染）4菌種 各10ケ所 マットレススチームディスインフェクション (蒸気除染) 1菌種2ヶ所計8ヶ所 2回実施 マットレスウォッシングディスインフェクション （温水洗浄除染）1菌種2ヶ所計 8 所
(4)培養方法

各工程終了後、 $10 \mathrm{ml}$ 滅菌ブイヨンへ入れ、 靦抖後、0. $1 \mathrm{ml}$ 取りHI寒天培地に培養し た。HI寒天培地は $36 \pm 1{ }^{\circ} \mathrm{C} て ゙ 72$ 時間、ブイ

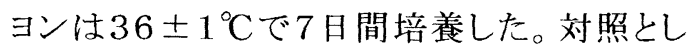
てディスインフェクション未実施の試験負荷に ついても培養した。

\section{【結果】}

ベッドウォッシングディスインフェクション (温 水洗浄除染)ではいずれの菌種・配置でも菌 堿少は著しく、マットレススチームディスインフ エクション(蒸気除染)、マットレスウォツシング ディスインフェクション(温水洗浄除染)でも同 様であった。洗浄タンク水・リンスタンク水は循 環再利用されるが、それぞれ条件別に高温維 持されており、よってタンク水中に試験菌液の 存在は全く認められなかった。また、どの試験 負荷も付着血液の污染は、配置に関係なく均 等に洗浄され、除去されていた。

\section{【考察】}

ベッド・マットレスともにベッドウォッシャー実 施前の対照にはいずれの菌種も $10^{8} / \mathrm{ml}$ 生 存菌が認められ、ブイヨン中には血液による 濁りが生じ污染が認められたが、ベッドウォツ シャー実施後は菌種・配置に関わらず非常に 良好な洗浄・殺菌効果が得られている。その 結果、院内感染防止対策への貢献も可能で あると考えられる。しかし、今後はこの環境清 浄度を維持しているか否かについて定期的な 試験負荷検查が必要となる。 


\author{
佐藤祐二（サトウユウジ） \\ 茨城西南医療センタ一病院 \\ 西雅明，石田智之
}

感染対策マニュアル・実践

（緒言）当院では平成8年度に院内感染対策 マニュアルを作成・使用したが，このマニュ アルは消毒剂一般論から各部門別対策に至る まで内容を網羅的に収載しようとしたため

に, 分厚く, 文字数が多く, 職員が気軽に手 にとって見るには不向きであった. また，内 容の改訂も簡単にはできるものではなかっ た. 今回，単なる病棟の備品としてではなく 職員が手軽に常時参考にできる生きたマニュ アル造りを目指して感染対策マニュアルの作 成を行ったので，その主旨を報告する.

(方法)

1. 感染対策マニュアルを, 実際に感染症が 発生した場合の対処法を収載した「実践

編」，消毒剂の作用原理，各疾患の説明など 感染対策および感染症に関する一般的知識を 収載した「基礎編」，透析室・手術室など各 部門別独自の感染対策を収載した「部門編」 の3部に分割した.

2.「実践編」は薄く手軽であることを第一 とした. 各疾患 (項目) については1ページ の割り当てを原則とし，内容の変更を容易に するため差し替え可能なファイル形式とし

た.さらに，最新の情報を提供することを目 的として巻頭に県衛生部，保健所等から送付 される感染情報などを収載する「最新情報ス ペース」を設けた。
3.「基礎編」では参考書的内容を充実させ ることを目的としたため，従来の成書に準ず る体裁としたが,「実践編」から直接参考に できるよう配慮した。

4.「部門編」では各部門別の特殊な対策を 収載した。

5. マニュアルに基づく感染対策がなされて いるか否かは委員が現場を訪問することによ りチェックし，必要があれば現場に介入する こととした. マニュアルの内容については委 員会で適宜討議・改訂することとした.

(結果) 新しい感染対策マニュアルに対する 職員の反応は総会で報告する.

(考察) 院内感染対策マニュアルに求められ ることは, 感染症発生時の対応方法がすぐに 理解できることであり，各施設の実体に即し ていることであり, 内容が常に更新可能であ り，かつマニュアル自体が単に蔵書として保 管されているだけでなく，職員が普段から気 軽に手にとって内容を確認する気が起こるよ うな体裁をとっていることである. 内容豊富 で網羅的であることは利点ではあるが，内容 が一般の成書と同じではマニュアルをわざわ ざ作成する意味はない，当院のマニュアルは まず「実践編」を第一とし，さらに情報を必 要とする場合は「基礎編」で検索できるよう 配虑している. 


朝倉健一（あさくらけんいち）
由利組合総合病院内科、
鈴木 隆 同小児科

インフルエンザ、ワクチン、アマンタジン

【緒言】平成 11 年末から 12 年にかけての当 院のインフルエンザ流行について分析し、診 断キットの利用およびワクチンの勧奨や特効 薬の早期投与を行なうなどの対策について検 討したので若干の考察を加えて報告する。

【対策】今年のインフルエンザ対策としては、 (1)ワクチンをできるだけスタッフを中心に勧 めること、そして(2)救急外来を訪れたインフ ルエンザ患者に対して、アマンタジンをでき るだけ発症早期に投与するようにしたことで ある。また、内科と小临科外来では、(3)イン フルエンザAが疑われた患者に対して診断キ ットを用いて迅速な診断を行なうようにした。 【結果】内科および小児科外来を訪れたイン フルエンザ患者数は、グラフに示すとおりで あり、例年同様 12 月末から 2 月後半まで流行 が続いた。小览科で、インフルエンザ脳症に 罹患した 1 例の死亡が確認されている。1月 中旬からインフルエンザ流行情報を流し、救 急外来にアマンタジンを置いた結果、翌日に は解熱する奏効例も少なくなかった。また、 インフルエンザ $\mathrm{A}$ 診断キットは、咽頭ぬぐい 液よりも鼻汁からの陽性率が高い印象を受け た。しかし、キットが沉用されたため、すぐ にキット不足になったことが問題である。

【考察】これまでのインフルエンザ対策と大 きく異なる点としては、診断キットが開発さ れ迅速にインフルエンザA と診断することが 可能になった点と、アマンタジンやザナミビ ルといった特効薬が開発され、早期治療によ
り速やかに治癒させることが可能になったこ とである。そこで、救急外来にアマンタジン を置くことにして、できるだけ早期に投与し てもらうように当直医にお願いし、予想以上 の劇的な効果がみられた。一方、小児科では、 特効薬は使えない状況ではあるが、脳症発症 の予防の面からもワクチンの積極的な投与を 勧めている。今回もワクチンは十分に供給さ れたとは言いがたく、ワクチンをしなかった スタッフの間でもかなりの流行がみられた。 今年度は、病院全体として職員全員へのワク チン接種を検討している段階である。

【結論】当院において実施されたインフルエ ンザ流行への対策について報告した。小児の 場合はワクチンがもっとも予防に効果があり、 成人においては、発症早期のアマンタジン投 与が効果的と考えられた。

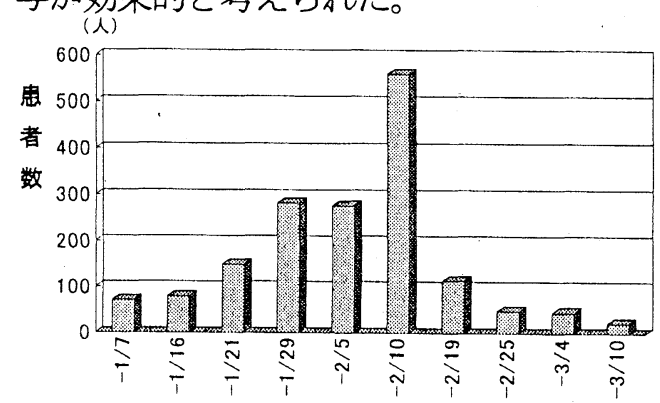

期 間

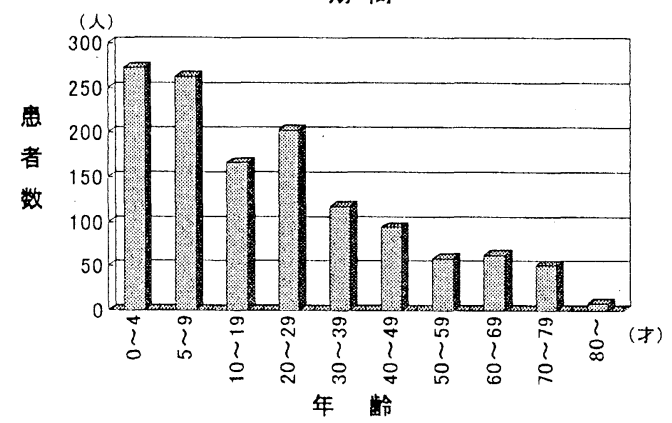


2D31 びまん性汎細気管支炎のradiologic-pathologic correlationの検討

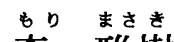

森 雅樹

札幌厚生病院呼吸器科, 同 臨床病理科* 大内博文, 村岡俊二*

びまん性汎細気管支炎, 伸展固定肺, CT

【はじめに】びまん性沉細気管支炎 (diffuse panbronchiolitis: DPB) は, 両 肺びまん性に存在する呼吸細気管支領域の 慢性炎症を特徵とし, 呼吸機能障害をきた す疾患である. 1995年に厚生省研究班によっ て示されたDPB診断の手引きでは, 胸部X 線所見や胸部CT所見が臨床診断上重要視さ れている，今回我々は，臨床的にDPBと診 断され約 9 年後に呼吸不全で死亡した症例 の剖検肺を用いて, 胸部CT所見と組織学的 所見とを比較検討したので報告する.

【症例】症例は41歳（死亡時）, 男性. 平 成2年8月, 咳嗽, 喀痰を主訴に当科外来を 初診. 胸部X線写真で両肺野にびまん性粒 状影を, 胸部CTでは小葉中心性分布を呈す る粒状影を認めた。他の検査所見結果と併 せて臨床的にDPBと診断し, エリスロマイ シンの少量持続投与を開始した. 当初症状 や胸部CT所見は改善傾向を示したが，その 後しだいに呼吸困難や胸部CT像での気管支 拡張像が進行し, 平成 11 年 4 月呼吸不全の ために死亡した.

【方法】剖検肺は, Heitzmanの方法に従っ て伸展固定を行った. 中枢気管支にカニュー レを留置し, $30 \sim 50 \mathrm{~cm} \mathrm{H} 2 \mathrm{O}$ で胸膜が軽く 伸展するまで固定液を注入した. 固定液は, ポリエチレングリコール400，95\%エタノー ル, ホルマリン, 水を10:5:2:3の比率 で混和したものを用いた．注入後の肺はそ のまま 3 日間程固定液に浸漬した後, コン プレッサーで空気を連続的に送り固定液を
除去し，乾燥した伸展固定肺標本を作製し た. 標本は水平断方向に $5 \sim 10 \mathrm{~mm}$ 厚にス ライスし, 軟X線撮影を行った. 軟X線像と 実体顕微鏡によるサブマクロの分析から病 変を有するスライスを選択し, 標本の HRCT撮影を行った. 病理標本は, サブマ ク口所見, 標本の HRCT像の検討より切り 出し, ヘマトキシリンーエオジン染色標本 およびエラスチカーワンギーソン染色標本 を作成した. 病理像とHRCT画像の対比を 行い, 生前のCT像とも比較検討した.

【結果】臨床の胸部CTでは, 両肺の気腫性 変化, 気管支抎張像, 小葉中心性分布を呈 する粒状影が認められた. 伸展固定肺の軟 X線像およびHRCT像では，それらの所見 を明瞭に把握することが可能であった. DPBの最も特徵的な所見である小葉中心性 に分布する粒状影は, 肺動脈の先端に位置 乙, 肺静脈・小葉間・胸膜から離れて存在 していた. 病理組織標本のルーペ像では, 抎張した気管支・細気管支, および小葉中 心性に分布する小結節がびまん性に認めら れた. 病理組織学的には, 呼吸細気管支壁 とその周囲の間質に炎症細胞浸潤を伴う泡 沫細胞の集簇, リンパ球浸潤, 壁の肥厚, 内腔の狭窄および閉塞が認められた.

【結語】病理学的には呼吸細気管支の変化 が主体であった. サブマクロレベルでの主 要所見は気管支拡張像と曩胞性変化であり, HRCT像はこれらの肺構造の病理所見をよ く反映していた。 
2D32 BDP 治療中の高齢喘息患者での Fluticazone 変更時の臨床的検討

\section{おおばやしひろゆき}

大林 浩幸 1 )

JA 岐阜厚生連総合病院昭和病院内科 1), 同薬局 2)

市岡秀介 2), 竹内千恵 2), 宮地雅典 2), 野坂博行 1), 山瀬裕彦 1)

気管支喘息、Fluticasone propionate (フルタイド)、高齢者

【緒言】近年発売された Fluticasone propionate $(\mathrm{FP})$ は、従来の吸入ステロイド薬 Beclomethasone dipropionate(BDP)の約 2 倍の 臨床効果があり、若・中年者にとって、簡 便性・携帯性に優れた専用器での dry powder 吸入は、有用性が高い。しかし、手指の細 かい操作や素早い吸入を要する FP の吸入操 作は、高齢者には、必ずしも容易ではない。 【対象と方法】対象は、BDP にて安定し ている、ピークタローメーターでの自己管理中の 65 歳以上の外来喘息患者 47 名である。65-74 歳(35 名) $\cdot 75$ 歳以上(12 名)に分け、BDP 量 の半量を目安に FPに切り替え検討した。

1) 製造x-办-(GlaxoWellcome 社)の取扱説明 書に準じ、操作手順を 12 項目に分けた。

\begin{tabular}{|c|}
\hline 《薬(ディスク)の装着法》 \\
\hline 操作[1] : カパーを外し、トレーを引き出す。 \\
\hline 操作[2]：トレーを取り出す。 \\
\hline 操作[3]：薬（テイスク）をのせ、トレーをもどす。 \\
\hline 操作[4]：薬（ティスク）を回転させる。 \\
\hline 操作[5]：表示空の番号を確認する。 \\
\hline 《吸入方法》 \\
\hline 操作[6]：カバーをはずし、ふたを垂直に立て、真（デイスク）に穴をあける。 \\
\hline 操作[7]：苦しくない程度まで息を吐く。(吸入器に向けて息を吐かない) \\
\hline 操作[8]：吸入器を水平に保ち、側面の空気孔を塞がない㥞に、ロにくわえる。 \\
\hline 操作 $[9] ：$ 来早く深く藥を吸入する。 \\
\hline 操作[10]：吸入後にできるだけ艮く息止めをする（5秒程度)。 \\
\hline 操作[11]：ディスクを回転させ、残りの吸入回数を表示させ、確認する。 \\
\hline 操作[12]：吸入後に、うがいをする。 \\
\hline
\end{tabular}

専任の薬剂師が、各手技を瑟切丁寧に説明 後、患者一人でスムズに出来るかを検討した。 2）初回時に完全に出来るまで指導した後、 2-4週間目に、再度同じ項目を検討した。 その際に使用感と副作用のア次調査をした。 3) BDP 使用時と、FP 切替後 $2-4 \cdot 8$ 週後 の朝夕のピークワロー值、肺機能を比較検討した。
【結果】下図(A)は初回時、下図(B)は、2 4週後にスムーズな操作が出来なかった項目の 人数(\%)を示す。

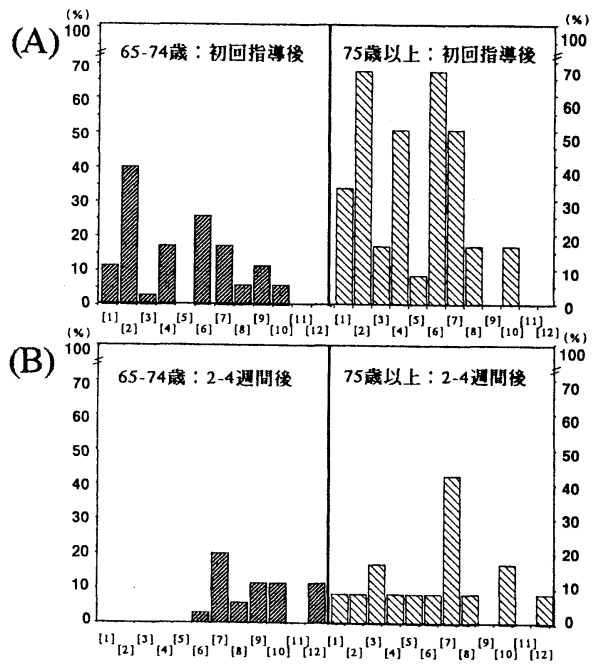

《朝・夕のピークフロー值》は、いずれも $2-4$ 週目より有為な改善が認められたが、肺機 能は、統計上の有為な改善は認めなかった。 《アンケート調查の結果》、最終的に FP を選択し た患者は、65-74 歳代で 25 名(71.4\%)、75 歳以上で 6 名 (50.0\%) であった。 《副作用》は、口腔中の乾燥感 7 名(14.8\%)、 嗄声 5 名(10.6\%)、悪心 - 嘔吐 2 名(4.3\%)。

【考察】高齢者喘息は、非アトピ一型、通 年性で難治性である事が多く、COPD 等の 合併、記銘力·手指運動機能低下による薬剤 服用のコンプライアンイの低下への留意が、治療上 重要となる。FP 剂は高齢者喘息治療上、有 用だが、特有の吸入器具操作に対し、高齢 患者自身の慣れを要する部分がある事を認 識し、繰り返し指導することが重要となる。 
2D33 5SリボソームRNA遺伝子を増幅するPCR法によるレジオネラ肺炎の遗伝子診断

$$
\begin{aligned}
& \text { 多 } n^{*} x^{\circ} \text { 七コ } \\
& \text { 高部和彦 } \\
& \text { (土浦協同病院・内科) }
\end{aligned}
$$

東中川光, 土屋公威, 福岡俊彦, 小平祥史、簿原陽子、藤原秀点

レジオネラ肺炎, PCR法, 5Sリボソー $\triangle R N A$ 遗伝子

\section{【緒言】}

レジオネラ肺炎は，市中肺炎の0〜 16.2 \%，院内肺炎の0～25\%を占めると報告され ている. しかし、レジオネラ属菌は特殊な培 地（BCYE $\alpha$ 培地）でのみ発育するため, 診断 には尿中抗原の検索や，遺层子検查が必要と なる場合が少なくない，我々は，5Sリボソー ARNA遺伝子を增楅するPCR法によるレジオ ネラ肺炎の遺伝子款断 (Murdoch et al., Eur J Clin Microbiol Infect Dis 1999）を本年より 開始し，すでに3例の陽性例を認め, 有用な検 查法と考えられたため報告する.

【対象と方法】

対象は，当院に入院したびまん性肺炎5例 で，3例は細胞診固定標本（気管支洗浄液1 例，略疾2例）から，2例は気管支洗净液から DNAを抽出した. 5SリボゾームRNA逼伝子の 104塩基対を增愊するプライマーを用いて PCRを行った. 本プライマーでは, 緑晨菌, Pseudomonas maltophiliaなど喠々の䋆菌で も增幅産物が得られるため, PCR産物に制限 酥素（Taq 1）を反応させ, 的70塩基対と30 塩基対に切断される場合を陽性とした. さら に，陽性例はdirect sequenceを行い塩基配列 を確認した. また, 可能な症例では尿中レジ オネラ抗原の測定を行った.

\section{【結果】}

湅胞診固定標本では2例（気管支洗净液, 楁 痰, 各1例）（症例1，2）, 気管支洗浄液で は1例（症例3）がレジオネラ陽性であった. 陽性例の胸部レントゲン所見は, いずれも両 肺びまん性の混合性肺炎像を呈した. 臨床所 見, 治療経過は以下のようであった. 症例 $1: 51$ 歳, 男性. 意識障害あり. WBC 6500 CRP 51.6 GOT 386
LDH 2610 CPK 24600.

人工呼吸管理を要し, エリスロマイシン (EM)， リファンピシン (RFP) を含む抗生 凧治㙩を行ったが死亡した.レジオネラ抗体 は128倍 (入院時, 4週間後) であった.

症例 $2: 71$ 歳, 男性. 榶尿病.

WBC 12200 CRP 21.4 GOT 99 LDH 579 CPK 1278.

呼吸不全を呈したが，人工呼吸管理は要し なかった. EM, RFPを含む抗生剤治療を行い 改善した. 尿中レジオネラ抗原陰性. 症例3: 58歳, 女性. 再生不良性貧血.

WBC 2920 Hb 4.5 PIt 2.1 CRP 7.4 GOT 21 LDH 600 CPK 148.

人工呼吸管理を要したが，第3世代セフェム 系抗生郕, バンコマイシンによる治㙩で改善 した. 尿中レジオネラ抗原陰性.

\section{【考察】}

レジオネラ属菌の遺伝子診断には種々のプ ライマーが報告されているが, 本プライマー は増幅塩基数が104塩基対と短いため, 細胞 診標本から抽出したDNAからも增幅が可能で あった. ただ，PCRのみではレジオネラ属菌に 特異的ではなく, 制限酻素による確認か必要 であった. また, Legionella pneumophilaの 血清型による塩基配列の相違が5Sリボソーム RNA遺伝子にはほとんどなく, sequenceによ っても細かな同定は困䧼と考えられた.

\section{【結語】}

5SリボソームRNA遺伝子を増幅するPCR法 によるレジオネラ肺炎の道伝子診断は，一般 病院でも施行可能であり，レジオネラ肺炎の 早期診断, 肺炎の起因菌のretorospectiveな 分析にも有用と考えられ，今後の症例の集積 が必要と考えられた. 


\title{
2D34 高齢者肺炎の新しい予防法一高血圧治療薬用いてー
}

\author{
新井 正（あらいただし） \\ 岐阜県厚生連岐北総合病院内科 \\ 安田 洋、高屋忠丈、伊東祐二、平野良尚、 \\ 早川和良、戸島 敏、渋谷智顕、樫木良友
}

高齢者肺炎、高血圧症、降圧薬、不顕性誤嚥

【緒言】私たちは これまでに降圧薬の一つで ある ACE 阻害薬が不顕性誤矒に有用であるこ とを報告した (Lancet 352:115-116、1998)。さ らに 65 歳以上の外来通院中の高齢者で、高血 圧を有する患者が、ACE 阻害薬投与により肺 炎発症が有意に少ないことを報告した （Lancet352:1937-1938、1998）。今回我々は 外来通院中の高齡者高血圧患者における ACE 阻害薬、Ca 拮抗薬およびAll 受容体拮抗薬の投 与による高齢者肺炎の発症について差異があ るか否かを検討し若干の知見を得たので報告 する。なお全症例に対して、本人または家族に インフォームドコンセントを得ている。さらに この研究を実施中、血圧が正常範囲内にコント ロールでき得た症例についてのみ検討した。

【対象】1995 年 1 月〜2000年 5 月までに当院 の外来で高血圧症の加療をうけている 65 歳以 上の 2785 人中、降圧薬を併用されている人 を除いた 1095 例（男性 484 例 平均年跉 77.3 歳、女性 611 例 平均年齢 76.9 歳) A 群:ACE阻害薬投与群535 例、男性245例 平 均年齢 76.1 歳、女性 290 例 平均年齢 76.8 歳、 B 群 : Ca 拮抗薬投与群 447 例、男性 248 例 平 均年柃 75.6 歳、女性 199 例 平均年齢 76.2 歳、 C 群 : All 受容体拮抗薬投与群 113 人、男性 36 例 平均年齢 75.9 歳、女性 77 例 平均年齢 75.2 歳

【結果】肺炎発症は $A$ 群 $2.8 \%$ (535人中 15 人) 、 B群 $8.1 \%$ （447人中 36 人）、C群 $8.0 \%(113$ 人中 9 人)であった。

【考案】以前より脳卒中直後に肺炎が起こりや すいことがしられていたが、その後の研究で、 老人性肺炎を起こす人は脳血管障害、特に大脑 基底核の血管障害を持っている人に多くみら
れることが判明した。大脳基底核の障害はこの 部位にある黒質線状体から産生されるドーパ ミンが少なくなる。ドーパミン産生の隇少は、 迷走神経知覚枝から気管などに放出されるサ ブスタンス P(SP)の量を減少させる。SP は咳 反射の源となる物質であるため、SP の減少は 咳反射を低下させ、夜間の不顕性誤䓵を増加さ せる。高齢者はこの不顕性誤鰙を絽り返すこと により肺炎を発症すると考えられている。我々 はこの不顕性誤燕を改善する薬物はないかと 研究した結果、降圧薬の一つである ACE 阻害 薬が不顕性誤與を改善することを見い出した。 このことから ACE 阻害薬を服用している高齢 者は、服用していない高齢者に比べて肺炎の発 症は少ないか否かを検討したところ、明らかに ACE 阻害薬を服用している高齢者が肺炎の発 症が低かった。6 歳以上の高齢者約 2000 万人 のうち $11 \%$ の 220 万人が要介護老人である。 これらの要介護老人の直接の死因は肺炎が最 も多く、約 $30 \%$ を占めている。一方肺炎の $92 \%$ は 65 歳以上の高齢者で占められており、肺炎 は高齢者呼吸器疾患としては最も頻度の高い 疾患である。このことから ACE 阻害薬が高跉 者肺炎予防に有用であることが示されたこと は、日常診療にも活用できると考えられた。

【結語】65 歳以上のいわゆる高齢者で高血圧 症で通院する患者においては、ACE 阻害薬の 投与により高齢者肺炎の発症が抑制されてい ることが示された。このことから高齢者肺炎発 症予防を念頭に置くならば、高齢者高血圧症の 治療には、特に投薬禁忌例を除き ACE 阻害薬 を投与することが望ましいと考えられた。 
脳血管障害入院患者における嚥下障害の評価について （VFとシンチグラフィーを用いた誤燕判定の有用性）

\begin{tabular}{|c|c|c|c|c|}
\hline 末松 $太^{11}$ & 安田 洋 ${ }^{2}$ & 新井 正 $^{2)}$ & 伊東祐二2) & 早川和良 ${ }^{2)}$ \\
\hline 平野良尚 ${ }^{21}$ & 高屋忠丈 ${ }^{21}$ & 太田明宏 ${ }^{11}$ & 杉田峰子 ${ }^{11}$ & 尾関裕一1) \\
\hline $\begin{array}{l}\text { 兼村武浩 }{ }^{11} \\
\text { 樫木良友 }{ }^{4)}\end{array}$ & 山田 正 ${ }^{11}$ & 松野俊一1) & 田中史朗 ${ }^{1)}$ & 辻本真紀 ${ }^{3)}$ \\
\hline
\end{tabular}

(岐北総合病院放射線科 ${ }^{11}$ 内科2)リハビリテーション科 ${ }^{2)}$ 外科 $\left.{ }^{41}\right)$ VF シンチグラフィー 䛊燕

\section{【はじめに】}

近年、老年者の肺炎は最も死亡率の高い 疾患の一つと言われている。特に、燕下反射 や咳反射の低下を原因とする誤㗆性肺炎は、 全身状態の機能の低下した脳血管障害入院患 者の多くに見られ、嚥下障害の有無の判定や 嚥下訓練の効果の判定には、覚醒鮰下時の $\mathrm{X}$ 線透視を録画観察するvideo-fluorography ( VF) が有用といわれている。しかし、誤燕 性の肺炎を予防するためには、夜間睡眠時の 不顕性誤㗆についても評価すべきと思われる 。今回我々は、誤嚥性肺炎を疑った脳血管障 害入院患者について、VFとシンチグラフィ 一を用いて覚醒時と睡眠時の詔燕の有無の判 定を同時期に行って検討したところ、若干の 対完を得たげて報名する。

\section{【対象及び方法】}

当院で誤燕性肺炎を疑った脳血管障害入院 患者で、当検査の必要性について患者本人ま たは家族の了解を得た患者を対象とした。

使用機器は、低エネルギー用高分解能コリ メーターを装着した島津ガンマカメラシステ ム (SNC-5100R) 、日立製デジタルX線透視装 置(TU-3000) を用いた。

シンチグラフィー撮像方法は、 ${ }^{99 \mathrm{~m}} \mathrm{~T} \mathrm{c}$ スズコロイド (160MBq) 1ccを就寝前に口腔内 に注入し、翌朝約12時間後の仰臥位胸部正面 像を撮像時間 300 secでおこなった。撮像範囲 は、口腔から上腹部までを含めた。VFの方 法は、低浸透圧の血管造影剤（イオパミロン 370)を一口あたり 3〜 $5 \mathrm{~m} 1$ 噮下するときの 口胿から食道上部までの様子について、X線 透視装置のモニター画像をビデオ記録した。

\section{【結果および考察】}

VFは、嚥下運動のすべての過程を記録観 察できるために、燕下障害の部位と程度を診 断するのに最も信頼性の高い検査法といわれ ている。特に知覚低下のために、むせを呈し ない誤燕を評価する場合には、極めて有用と 思われた。当院では脳血管障害入院患者にお ける器下障害に対して、誤燕性肺炎を予防す ることを目的として、VF結果にもとずいた 嚥下機能訓練を積極的に行っている。VFに よる器下機能訓練の効果判定は、経口摄取の 開始の判断の一つとして有用と思われた。し かし、VFで誤燕認められなくともシンチ グラフィーで誤囬があると判定した症例があ った。不顕性誤蔡性肺炎の起こりうろ危険性

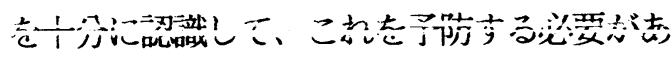
ると思われた。

\section{【まとめ】}

脳血管障害入院患者における誤誉性肺炎の 䂆防のためには、VFのみならず、シンチグ ラフィーを用いた睡眠時の誤燕につても評 価する必要があると思われた。 


\section{循環器疾患 4}

2D36 人間ドック受診者における低電位差例についての検討

しばたやすたか

柴田康孝、井上美奈、左右田昌彦、野田由美子

西尾諭美香、後藤武雄、*石川真一

(愛知県厚生連昭和病院 生理検査室 $*$ 循環器内科)

低電位差、肥満度、体脂肪率

【はビめに】心電困の低電位差は心筋起電力 の低下・心囊液貯留・肺気腫などに際し認め られる。今回、肥満と低電位差との関連を人 間ドック受診者において検討したので報告す る。

【対象】当院健診センターにおいて、平成10 年1月から平成11年12月の2年間に人間ドック を受診した 9,523 例のうち心電図検查で肢誘 導低電位差と診断された75例を低電位差群と した。対照群として平成 11 年の受䛦者 5,216 例を用いた。

【方法】低電位差群はQRS波の振幅が全肢誘 導で0. $5 \mathrm{mV}$ 以下であるものとした。肥満の指 標として、(1)肥满度を [(体重一標準体重)/標 準体重 $] \times 100 ：$ 標準体重 $=$ 身長 $\left.(\mathrm{m})^{2} \times 22\right\}$ により算出した。(2)低電位差群では体脂肪率 を「TANITA製TBF-202」により測定し、男 性14 23\%、女性17２7\%を”適正”、それ 以上を”肥満”、以下を”贏瘦”とした。

【結果】(1)低電位差群は男性5,781例中 20 例 (0.35\%)、女性3,732例中55例 (1.47\%) であ つた $(\mathrm{P}<0.001)$ 。(2)低電位差群の体脂肪率 は約80\%が”適正”に属するが、女性の $22 \%$ が肥満㑯向、男性の $20 \%$ カ渡せ傾向であった (図)。(3)巴満度の平均値は、全体では低電位

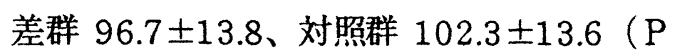
<0.01）；男性は低電位差群 93.1 \pm 14.6 、

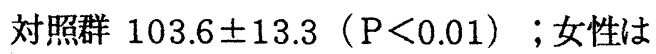

低電位差群 $98.0 \pm 13.4$ 、対照群 $100.1 \pm$ 13.9（ $\mathrm{P}=0.26 ）$ であった。低電位差群の 男女間の肥満度には有意差はないものの、男 性においては低い傾向が見られた。

【考察】低電位差群においては肥満度から判 定される肥満傾向は観察されず、男性におい てはむしろ瘦せていた。女性では対照と差が 無かった。これに対し、肥満を体脂肪率で評 価すると、女性には”瘪瘦”はなく”肥満”の側 に分布が傾いており、男性における均一な分 布とは異なっていた。体脂肪率は体内の電気 抵抗を基に測定され、一方体内の電気抵抗が 高い場合に心電図上低電位差となると考えら れることから、女性の高体脂肪率例における 低電位差の成因として体内脂肪分布の影響の 関与の可能性が示唆される。低電位差の成因 としては上記のほか体形などの影響による誘 導ベクトルの変化も考えられるが、低電位差 の男性の肥満度が低い理由は今回の検討では 不明であった。

（図）低電位差群における体脂肪率の分布

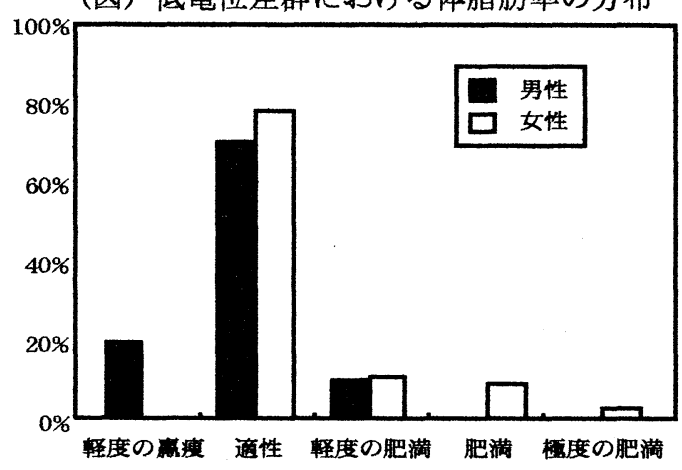


2D37 冠動脈と頝動脈に高度閉塞性合併病変を持つた症例の臨床的特徵の検討

金子兼喜（カネコカネヨシ）

山本組合総合病院循環器科

渡部葉子・小川康彦・照井 元

危険因子の重複・頝動脈エコー・無症候性䅡動脈病変

〈緒言〉䅡動脈病変を検出するためのエコー 検査の導入にて、頝動脈病変は循環器科医に とっても稀なことではなくなってきた。脳梗 塞の病因と血行力学的機序についてはいまだ 議論の余地はあるが、今後の患者管理に活か すために冠動脈と頝動脈に高度の閉塞性合併 病変を持つた症例の臨床的特徵について検討 したので報告する。

〈方法〉冠動脈病変は冠動脈造影検査にて診 断し、頝動脈病変は頝動脈エコーに続いて 行ったヘリカル C T 造影三次元画像にて診断 した。平成10年11月より $2 つ の$ 検查法にて診 断し得た冠動脈と頝動脈に $90 \%$ 以上の閉塞 性病変を持った症例は 11 例あり、この 11 例を 対象とした。男性 10 例、女性 1 例で、平均年 齢は70.1歳であった。危険因子や病変診断の 患者背景と治療内容、転帰について検討した。

〈結果〉 1 . 受㟝時症状は狭心症症状が3例、 一過性の脳虚血症状が5例、その他が3例で あった。2. 冠危険因子は高血圧症が 11 例中 10例、喫煙が8例、糖尿病が6例、高脂血症が 4例であった。 3 . 冠動脈病変数は3枝病変が 11例中7例、左主幹部病変または2枝病変が2 例、 1 枝病変が 2 例であり、心筋虚血病態は、 不安定狭心症が1例、労作性狭心症が 3 例、無 症候性心筋虚血が7例であった。4. 頚部理学 所見上血管性雑音が聴取されたのは 11 例中 8 例あったが、5例では大動脈弁雑音が聴取さ れた。振戦または拍動の減弱から狭窄が強く 疑われたのは3例だけであった。5.頝動脈病
変は総頝動脈が 1 例、内頝動脈が 10 例であり、 内頝動脈の5例は閉塞していた。脳梗塞は3例 にみられ、1例は無症候性であった。6.冠動 脈に血行再建術を行ったのは5例、頝動脈に 血行再建術を行つたのは5例あった。冠動脈 と頝動脈の両者に血行再建術を行つたのが3 例あった。4例には抗血小板療法を行つた。

7. 診断後9例は心事故あるいは脳事故の合 併なく経過しているが、冠動脈バイパス術が 行われた左主幹部病変の 1 例は周術期心原性 ショックとなり、高度意識障害を合併し術後 1 ケ月に死亡した。抗血小板療法の 1 例は、 3 ケ月後に閉塞内頙動脈領域の脳梗塞を発症 した。

〈考察〉危険因子が重複したことから冠動脈 と頝動脈の合併病変の多いことは予測される が、従来、わが国では欧米の報告に比べて䅡 動脈病変は著しく少なかった。しかし、全身 性血管障害の理解とエコー検查の䅡動脈への 応用などの診断技術の普及により、わが国で も頝動脈病変の增加が報告されている。いま だ臨床経験が少ないため日常診療における合 併病変を持った患者の実際の治療においては 欧米の治療基準を参考にしているが、多数の 研究報告を基にしたわが国での治療指針の確 立が望まれる。

〈結論〉䅡部理学所見だけに基づいた高度狭 窄病変診断率は低く、無症候性病変の検出を も意図した頝動脈エコーによるスクリーニン グ検査が重要である。 
2D38 造影剤の血管外漏出を生じた脳内出血にて発症し、出血をくり返したモヤモヤ病の一例

中村達美 (ナカムラタツミ)

$\mathrm{JA}$ 秋田厚生連 北秋中央病院 脳神経外科

モヤモヤ病 脳内出血 血管外漏出

【始めに】最近我々は、巨大な脳内出血で発 症し、発症直後の脳血管撮影にて造影剂の血 管外漏出を認め、引き続き施行した血腫除去 術により比較的良好な経過を辿っていたもの の、その後、9 ケ月の間に 2 回の出血をきた したモヤモヤ病の成人例を経験したので、多 少の考察を加えて発表する。

\section{【症例】 26 才 女性、}

主訴 : 頭痛を訴えた後の意識低下

既往歴 : 麻疩、㾏攣などの既往はない

現病歴: 平成 11 年 2 月 19 日仕事中、急に 頭痛を訴えて倒れたため、救急車にて当科を 受診した。受診時、意識J.C.S III-100、左完 全片麻疩を認め、頭部 CT にて右基底核を中 心に巨大な血腫を認めた。

入院後経過 : 直ちに施行した脳血管撮影で は、両側の内䫋動脈は末端部で著しく狭窄し、 末端部付近からは異常血管網を多数認め、右 側では外側の異常血管より造影剂の漏出が認 められ、モヤモヤ病およびモヤモヤ血管の破 綻による脳内出血と診断した。この間、意識 はIII-200 となり、右瞳孔も散大してきたため、 ただちに、開頭血腫除去術を施行した。手術 2 个月後には、意識はほぼ清明となり、 5 月 21 日には、間接的血管吻術 (EDAS： Encephalo-Duro-Arterio-Synangiosis）を施 行した。リハビリテーションの結果、電動車 椅子を自力で操作しての移動は可能となり、 平成 11 年 10 月 8 日転院した。

再入院までのとその後の経過: : 11 年 10 月
16 日転院先の病院にて、頭痛を訴えた後、嘔 吐し意識が低下した。CT にて右大脳半球に 出血を認めたため、当科に転院となった。CT では前回とは異なる部位に脳内出血を認め、 脳室内にも穿破していた。意識は JCS III -200、右瞳孔は散大していた。家族の希望も あり、再び開頭、血腫除去を行った。術後 3 日目頃からは簡単な命令に従うようになり、 リハビリテーションを行っていたが、11月 1 8日急に反応が鈍くなったので、CT を撮つ たところ、左頭頂側頭葉に皮質下出血を新た に認めた。保存的に加療した後、現在、リ八 ビリテーション中であるが、意思の疎通は不 能で四肢麻痺の状態である。

【考察】モヤモヤ病が脳内出血で発症した場 合、基底核部に動脈瘤を認めなければ。その 原因は、モヤモヤ血管の破綻によるものと言 われているが、本症例は、extravasation に よりこれを確認できた貴重な症例と思われる。 また、現在、間接的血管吻合術がモヤモヤ病 の出血例に有効であるか否かについては議論 もあるが、他に出血を防ぐ有効な手段がない 以上、出血にて発症した例では、本症例のよ うに致命的な出血をくり返すことがあり、両 側の間接的血管吻合術をなるべく早期に実施 することが必要と思われた。 
2D39

当院における局所脳血流值評価（第4報）

佐久総合病院 RI検查空
叔と切

O依田度勝 高見沢雅夫 并出隆行 小林 淳

\author{
同脳神経外科 \\ ダイアモックス負荷 血管反応性
}

はじめに 正常な脳組織ではダイアモックス (acetazolamide) を静脈投与することにより脳 血管が虹張され脳血流は増加するが、虚血に陥つ ている脳組織ではこの脳血管拡張能力失われ 脳 血流の増㽖見られないこと力知られている。 このような血管反应性 (以下、反応性) を利用し たダイアモックス負荷局所艁血流定量検查は、主 に血行力学的な脳虚血に刘する脳循環予備能 (血 管反応性(示す) の評価に有用であると考えられ ているため、脳血管吻合術等の適応判断目的で行 われることか多いしかいだこの検查における 適切な手術適尤基準は確立していない

今回第4報では当院で行われた検查症例をもと に、手術適尤基準の基礎的データとしてダイアモ ックス負荷における血流値や反応性の変化を中 間的にまとめたので報告する。

文象・方法 内䣆動脈系の閉塞または狭窄のため 血行力学的な脳虚血を有している男性のみ 17 名 (合計 272 ROI) を刘象とした。いすれも1 ケ月以内に安静時および負荷時定量検查を行っ た症例で、平均年齢は62.9歳であった。そして 症例ごとに、読影しポートをもとに正常反応部位 (反応性上昇部位) と低下部位を判別儿、血流值 およひ汳応性等の変化を検討した。

・血流值の単位は $(\mathrm{ml} / 100 \mathrm{~g} / \mathrm{min})$ を使用する。 結果・考察 1 .ます䛀応性低下部位につい 調べたところ、安静時平均血流值は約28で、負 荷時平均血流値は約 31 であった。よって反応性 低下部位での反応性は 10.7\%となり、この値(又 はこの值以下）力脳血管拡張能の限界値と考えら れた。また正常反応部位ては、安静時平均血流值 は約29で、負荷時平均血流值は約40であった。
よって正常反庥部位での反応性は 38\%となり、 この值が当院における正常脳組織の平均的な正 常反応値亡考えられた。

2. 反応性低下部位およひ正常反応部位における 安静時血流値と負荷時血流値の関係を連続的 风軸:安静時 Y軸:負荷時)に調べたところ、 反底性低下部位では、安静時血流值が 14 40

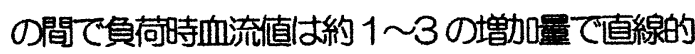
に推移した。また正常反応部位でも，安静時血流 值が20５0の間で負荷時血流值は約9～11増 加酉でほほ道線的な推移を示した。

3. 今回の症例 1 7例中、実際二脳血管吻合術等 の手術力施行されたのは3例であつた。(17.6\%) また当院の脳神経外科が原則的に手術適応の基 準としている幾つかの項目の中で<安静時血流 值力正常血流值の $80 \%$ 末満 かつ反底性が $10 \%$ 末満>の項目に適合する症例は3例あったが、こ の中で実際に手術力゙施行されたのは1例のみで あった。（5.88\%）よって上顃目による手 術施行症例は非常に少ないと思われた。 4.上記1例のみの症例を簡単に紹介する。

\section{9 歳 男性 右中大脳動服閉塞}

血管伆合術施行(Rt STA-MCA bypass) 閉塞部位における手術前の安静時血流值は 19.94 で反応性は8.27\%であつた。手術後、安 静時血流値は20.84 で大きな变化を示さないも のの、反応琍は $47.1 \%$ 之飛躍的な上昇を認内。 脳循環予備能の改善かみられた。変化は、本 例におけする血管吻合術の有効性を示している。 結語 将来におけるる手術適㡳基準の確立のために、 今回まとめた結果を基礎的データとして役立て たい 
2D40 過去7年間当科で経験した脳出血 一初回出血症例の検討一

柳田範隆 国塚久法 やなぎだのりたか くにずかひさのり 雄勝中央病院脳神経外科

脳出血

I はじめに

我が国では脳出血は脳卒中の約3割を占

め、男性が多く、約 $80 \%$ 䯩血圧を伴ってい ると報告されている。しかしなから、最近保 健衛生の向上などに伴い発症形態が変化しつ つある。今回我々は過去7年間に当科で経験 した脳出血を検討し、若干の知見を得たので 報告する。

\section{II ·対象}

1992 1998年の7年間に当科で経験した脳 出血は392症例で、初めて出血した症例が 350 例、再出血症例が 42 例で出血総数は 420 件であり、この間初めて出血した 350 症例を 検討した。

III 結果

対象350例の内訳は男性が184例、女性が 166例で男女差はなく、年齢は11-94歳で、 平均年齢は65.1歳であった。追跡期間は6ヶ 月から7年6ヶ月(平均3年6ヶ月)で、再出血症 例は19例にみられ、再出血率は6.1\%であり 年間再出血率は $1.74 \%$ あっむた。年代別にみ ると男女とも 60 代にピークを示すが、女性と 比較し男性ではやや若年で発症する傾向がタ られた。月別にみると2月、5月、6月が5例 以上と比較的多く、8月が1.7例之極めて少な かった。出血部位は被殼が42.3\%、視床が $29.7 \%$ 、皮質下 $11.1 \%$ 、小脳 $10 \%$ 、橋 $5.4 \%$ 、 尾状核 $1.1 \%$ 、中脳 $0.3 \%$ ありり、出血量は1$130 \mathrm{ml}$ て平均血腫量は $21.9 \mathrm{ml}$ でった。手術 は51例に施行され、その内訳は開頭血腫除去 術が16例(平均血腫量 $78 \mathrm{ml}$ )、定位的血腫除 去術が25例(平均血腫量 $36.7 \mathrm{ml}$ )、脳室ドレナ ージが10例であった。発症6ケ月のADLはI が34.9\%、IIが19.7\%、IIIが25.4\%、IVが

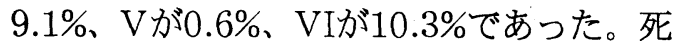

亡した36例の内訳は、被殼18例、視床3例、 皮質下3例、小脳5例、橋7例であり、出血部 位別からみた死亡率はそれぞれ $12.2 \%$ 、

$2.9 \% 、 7.7 \% 、 26.3 \% 、 36.8 \%$ ありり、死亡率 は橋、小脳で高く、視床で極めて低かった。 背景因子としては高血圧229例(39例は未治 療)、糖尿病43例、高脂血症31例、腎不全 9 例、肝疾患6例、出血時間延長6例などが挙げ られた。

\section{IV 結論}

1)従来脳出血は男性に多く発症するとされて いたが、我々のシリーズでは男女差がな かった。

2)脳出血の発症を月別にタると、2、5、6月 に比較的多く、8月が少なかった。

3)平均血腫量は $21.9 \mathrm{ml}$ であり、比較的小出血 が多いことが明かとなった。

4)出血部位別の死亡率は、橋、小脳が高く、 視床で極めて低かった。

5)高血圧症は $66.5 \%$ 々られ、従来の報告と 比較し、高血圧は脳出血の因子としては相 対的に低下していた。 
過去7年間当科で経験した脳出血 一再出血症例の検討一

柳田範隆 国塚久法 やなぎだのりたか くにずかひさのり 雄勝中央病院脳神経外科

脳出血 再出血

I はじめに

脳出血の再発に関しては、これまでのとこ ろその実態が明かとなっていない。今回我々 は過去7年間当科で経験した脳出血を分析・ 検討し、若干の知見を得たので報告する。

II 対象

1992 1998年の7年間に当科で経験した脳 出血は392症例で、初めて出血した症例が 350例、再出血症例が42例で出血総数は420 件であった。初回出血のみの群が331例、再 出血群は47例、再々出血群は13例、再々々 出血は1例であり、各群について検討した。

III 結果

初回出血のみの群は331例で、男性が174 例、女性が157例で、平均発症年齢は65.2歳 であった。出血部位は被殻 $42.9 \%$ 、視床 $30.2 \%$ 、皮質下 $10 \%$ 、小脳 $10 \%$ 、橋 $5.4 \%$ 、尾 状核 $1.2 \%$ 、中脳 $0.3 \%$ で、平均出血量は 22.4mlであった。発症6ケ月後のADLは汭 34.7\%、IIが19.0\%、IIIが25.3\%、IVが 9.4\%、Vが0.6\%、VIが10.9\%であった。

再出血群は47例で、男性が20例で女性が 27例であり、女性に多い傾向がみられた。初 回出血および再出血の平均年齢は、それぞれ 57.7、63.8歳で再出血までの期間は6.1年で あった。出血部位をみると、初回出血は被殼 $44.7 \%$ 、視床 $23.4 \%$ 、皮質下 $14.9 \%$ 、小脳 14.9\%、橋2.1\%であり、再出血は被殼 $42.6 \%$ 、視床 $36.2 \%$ 、皮質下 $14.9 \%$ 、小脳 $4.2 \%$ 、尾状核 $2.1 \%$ で、再出血群の平均出血 量は $23 \mathrm{ml}$ でった。ADLをみると再出血前 は功55.3\%、IIが34.6\%、IIIが8.5\%、IVが

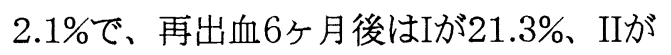
17\%、IIIが23.4\%、IVが21.3\%、VIが17\%で あり、再出血後は著しくADLが低下した。
再々出血群は13例で、男性が6例で女性が 7例であり、初回出血、再出血、再々出血時 の平均年齢はそれぞれ56.7、64.5、67.8歳で あり、再出血、再々出血までの期間はそれぞ れ7.8、3.3年であった。出血部位をみると、 初回出血は被殼が8例、視床が1例、皮質下が 3 例、橋が1例で、再出血は被殼 2 例、視床 5 例、皮質下、小脳がそれぞれ3例で、再々出 血は被殼が2例、視床が3例、皮質下が4例、 小脳、橋がそれぞれ2例であり、再々出血は 相対的に被款、視床以外の部位に多くみられ た。ADLについては初回出血後は明らかでな いが、再出血6ケ月後Iが 2 例、IIが6例、III が4例、IVが1例で、再々出血6ヶ月後IIが1 例、IIIが6例、IVが4例、VIが2例であり、 再々出血によりADLはさらに低下した。

また再々々出血した症例は66歳の女性で、 初回出血の年齢は不明であったが、再出血、 再々出血はそれぞれ49、64歳であった。出 血部位は右被殼、左被殼、左視床、右視床の 順であり、最終的なADLはIVであった。

再出血群と再々出血群、再々々出血群の二 回目の出血は61件で初回出血部位と比較検討 すると、初回被殼出血は30例で、再出血部は 対側被殼が13例、対側視床が8例と再出血は 対側被殼・視床に多くタられた。一方初回視 床出血は12例で、再出血部は対側視床5例、 対側被殼3例、同側被殼、視床がそれぞれ1 例、皮質下2例であり、初回視床出血の症例 では相対的に対側視床に再出血する傾向が示 された。また初回皮質下出血は10例で、再出 血部は皮質下4例、被殼、視床がそれぞれ2 例、小脳、尾状核がそれぞれ1例であり、初 回皮質下出血の症例では皮質下に再出血する 傾向がタられた。 


\section{D42 無症候性脳梗塞における血小板放出反応の意義}

\section{山本 直人（やまもと なおひと）} 愛知県厚生連海南病院 脳神経外科

棚澤 利彦、岡田 健、泉 孝嗣、中坪 大輔 無症候性脳梗塞、危険因子、血小板放出反応

【はじめに】21 世紀を目前にし、今後ますま す少子高跉化がすすむなか、厚生省は、健康 日本 21 と称し、生活習粯病を中心にその一 次予防を重視したプロジェクトを策定淮備し ている。勿論そのなかには、国民 3 大疾患の 脑卒中もふくまれており、さらに、なかでも 脑梗塞は、今後の受療率の增加が見込まれて いる。無症候性腷梗塞は、症候性の危険因子 とされながらも、その病態はいまだ不明な点 も多く、日常臨床においてその管理に迷うこ ともある。今回、無症候性脳梗塞患者におい て、血小板放出反応を测定し、患者管理にお いてその意義づけをし若干の知見を得たので、 文献的考察を加え報告する。

【対象および方法】当院脳ドックおよび脳神 経外科外来に受診した無症侯性脳梗塞患者 37 名で、男性 19 名、女性 18 名であり、平均年 龄は 60.2 歳であった。MRI は島津社製 1.5T を使用し、TACT-FLAIR 法で無症候性脳梗塞 を謤価した。血小板放出反応として、 $\beta$ - 卜 ロンボグロブリン ( $\beta$-TG)、血小板第 4 因子 （PF4）を测定した。尚、 $\beta$-TG および PF4 はともに、血小板の $\alpha$ 顆粒に存在する血小板 特異蛋白の一つであり、種々の刺激により血 小板から放出され、生体内での血小板活性化 を反映するとされている。RIA 法により比較 的容易に测定できるが、採血条件、検体の処 理により测定値に影管が出やすいので、注意 が必要とされている。

【結果】初回 MRI で無症候性腷梗塞を認め た患者は、5 名で、1 名は高値を示したもの
の、他の 4 名は正常であった。経年で MRI を追跡できた 32 名のうち、症候はないもの の MRI 所見が悪化した症例は 12 名あり、そ のうち血小板放出反応が高值を示したもの 8 名、残り 4 名は正常であった。また、MRI が 不変であった 20 名のうち、2 名のみが高値を しめし、他の 18 名は略正常であった。経年 でMRI を追跡できた症例で、実際脳梗塞を 発症したものは、みられなかった。

【考察】無症候性腷梗塞において、MRI 所見 が悪化する症例の $66.7 \%$ に血小板放出反応 の高值をみとめ、反対に MRI が不変であっ た症例の 90\%は略正常であったことより、本 测定值は、様々な危険因子の管理とともに、 無症候性腷梗塞の病態に重要な意義をもつも のと考えられた。血小板放出反応が高值をし めした患者に（大部分はラクナ梗塞であるた め)、抗血小板療法が必要かどうかは議論の 残るところであるが、近年ラクナ梗塞での、 执血小板療法の有用性も報告されつつあり、 当院では、チクロピジンを使用し、低下させ ている。

【結語】血小板放出反応は、ある程度、無症 候性脳梗塞の経過を反映すると考えられ、他 の危険因子の管理とともに慎重に観察するこ とが重要と思われた。また、ある年齢（50 歳 以上が目安と思われる）以上においては、脳 ドックの検查項目に組み入れることにより、 high risk group の抽出の可能性があり、意 義のあることと推测される。 


\section{$2 \mathrm{D} 43$ 過去 3 年間の当科における高齢者頚髄損傷 13 例の経験}

\section{田中公人、大山隆城、篠田幸子 松阪中央総合病院 脳神経外科}

\section{高齢者、頚髄損傷、頚椎脊柱管狭窄症}

[目的] 高齢者の頝骾損傷の原因、予後につ いて検討した。

[対象] 1997 年 4 月より 2000 年 3 月までの 3 年間で当科において経験した 70 才以上の 高齢者の頝髄損傷患者 (男 6 例、女 7 例、 70 才〜 82 才）を対象とした。[結果]頝髄損 傷の原因としては自転車事故 (3 例)、自宅 での転倒（4 例）、山作業転落（1 例）、骨䯣 炎 (1 例)、不詳 (4 例) であった。頝椎疾 患として脊柱管狭窄症 (11 例)、 $\mathrm{AAD}(1$ 例)、 OPLL（1 例）が認められた。症状は四肢麻

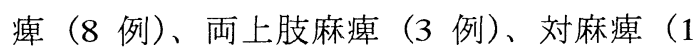
例）、頚部痛（1 例）であった。治療は 9 例 に外科的治療（椎弓拡大形成術 8 例、環軸 椎後方固定 1 例）を 4 例に保存的加療を施 行した。退院時神経症状は改善（10 例）、不 変 (3 例) で内 2 例は合併症により死亡され た。8 例の ADL は良好であった。[結論]春 柱管狭窄症の高齢者では軽微な頝椎外傷に より頝䯣損傷をきたす危険性を有するが、 不完全麻瘦であれば適切な内科的あるいは 外科的治潦により良好な ADL に回復するこ とが多い。 
2D44冷凍保存自家骨による頭蓋形成術の検討

清水重利（しみずしげとし）

鈴鹿中央総合病院 脳神経外科

森川篤囊、久我純弘、毛利元信

頭蓋形成、冷凍保存、自家骨

【目的】減圧開頭術後の骨欠損部の補填物質

として冷凍保存自家骨を用いた頭蓋形成術が 報告されているが、術後の骨吸収や感染など の問題が指摘されている。今回、我々は保存 液として Dimethylsulfoxide(DMSO)を用いた 保存方法により良好な結果が得られているの で報告する。【方法】症例は 1985 年より 1999 年までの 15 年間に当科にて冷凍保 存自家骨による頭蓋形成術を実施した 46 例 （クモ膜下出血 22 例、頭部外傷 13 例、 脳出血 6 例、脳梗塞 5 例) である。冷凍保存 期間は 16 日-232日（平均 55 日）であっ た。方法は骨弁を生理食塩水で十分に洗浄後、 滅菌容器内に $10 \% \mathrm{DMSO}$ (溶液として RPMI1640 リキッド「ニッスイ」の液体培地 を使用)を用い密封後、超低温冷凍庫にて 約 $-80^{\circ} \mathrm{C}$ に凍結保存し、使用時は自然解凍した。 【結果】一例のみ術後感染を生じ骨弁除去を 要したが、現在のところ骨吸収を生じた例もな い。【結論】頭蓋形成術に用いる補填物質とし ては美容面、手術の簡便さ、異物の使用を要し
ない点など自家骨に勝るものはないと考えられ る。一例で感染を生じているが、骨吸収の観点 などよりDMSO を用いた冷凍保存方法は有用な 方法と考えられる。

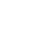


永山 徹（ながやま とおる）

白河厚生総合病院 脳神経外科

志田 直樹、佐々木 徹

末破裂脳動脈瘤・無症候性・治療成績

【目的】当施設の現時点における無 症候性末破裂脳動胍瘤の治療成績を検 討し、その問題点を明確にすることに よリ今後の治療成績の向上に寄与する ことを目的とした。

【対象と方法】当院にMR装置（シ ーメンス1.0T) が導入された1994年 7月から現在まで経験した、外来・脳 ドックにて施行されたMRA検查で偶 然発見された無症候性末破裂脳動脈瘤 症例15例を対象とした。男性7例、女 性8例、平均年龄63.3 吉 (男性56.9 寸・女性68.9才）で、動脈瘤の部位 は、中大脳動脈瘤10例・前交通動脈瘤 3例で、このうち1例はgiant aneurysm であつた。女性の2例では動脈瘤が多 発していた（1例では中大脳動脈瘤と 前交通動脈瘤に1個ずつ、他は両側中 大脳動脈瘤と前交通動脈瘤と内頝動脈 瘤の計4個）。対象症例全体で手術の 対象となつた動脈瘤は合計19個であつ た。治療は全例開頭手術とし、その手 術適応例は 最近は原則として70才 以下、 anterior circulationの裹状動脈 瘤、大きさは5 $\mathrm{mm}$ 以上、重篤な全身
合併症のみられない症例としている。 手術に際しては、必要に応じ術中 DSA、神経内視鏡、術中ドップラ 一を使用し、動脈瘤の確実な処置をめ ざした。

【結果】(1) 退院時のmortality、 morbidityとも0\%であつた。ただし 左中大脳動脈瘤の1例に穿通枝閉塞が 原因の一過性の軽度運動性失語症を認 めた。（2）手術のapproachは、比較 的sizeの大きな前交通動脈瘤の1例に 対L.interhemisperic approach 施行 し、他は全例pterional transsyluvian approachであつた。内頚動脈瘤に wrappingを施行、他の動脈瘤には全 てneck clippingを施行した。（3）術 中DSA、神経内視鏡、術中ドップラ 一の使用は動脈瘤の処置の確実性を高 め有用であつた。

【結語】当施設の現時点での無症候 性末破裂脳動脈瘤の治療成績は良好で あつた。ただし脳動脈瘤の処置にあつ たては、とくに穿通枝障害に注意が必 要と考えられた。 
消化器疾患・精神疾患・その他

\title{
2D46 消化器外科疾患と地域特性
}

\author{
矢簿品

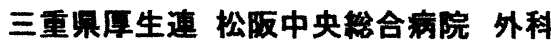 \\ 玉置久雄、三田孝行、大橋直樹、松本英一、安田淑子
}

\section{消化器外科手術地域较差 疫学}

[はじめに]三重県は伊乵湾から太平洋岸の熊野 粠にかけ、南北に細長く横たわる県で、県北中部 の伊勢平野(北勢、中勢、南勢地区)は農業、 県南部の沿岸部(志摩、紀州地区)は漁業を 主要な産業基盤としている。また老年人口比は 南下するにつれ高率となり、平均寿命は県中部 (内陸部)に高く、県南部(沿岸部)で低い(図1)。 以上より当県は地理·産業·疫学的に南/北、 内陸/沿岸で概ね 4 区分できる。かかる地域 特性と消化器外科疾患の頻度との関連について 検討した。

[対象と方法] [地域特性:北勢地区(鈴鹿市)， 中勢地区(久居市)，南勢地区(松阪市)，志摩 地区(阿児町)、紀州地区(尾型市)の5地区を 選定。各地区の人口、老年人口比、平均表命, 死亡率、農業指数(農家数/人口千対)、漁業 指数 (漁業戸数/人口千対)を検索。II.消化器 外科疾患の頻度: 診療圈がその地域に限定され た各地区の基幹病院における過去 5 年間 (1995 -1999)の総手術数 (全麻)、主要消化器外科 疾患手術数（胃癌、大腸癌、胆石)を検索。 [結 果] [.地域特性:農業指数は北勢、中勢 地区に高く、漁業指数は志摩、紀州地区で高い。 また老年人口比は北勢地区て低く(鈴鹿市 14 \%)、紀州地区で高い(尾第市 27\%)。男子 平均寿命 (県平均、76.0 歳)を地区別にみると、 中勢地区が最も高く(久居市 77.7 藏)、志摩、 紀州地区が最も低かった（阿児町 74.3 藏、 尾第市 74.4 藏)(图1)。II. 消化器外科疾患 の頻度: 胃癌、大腸癌、胆石症は、主要消化 器外科疾患であり、何れの地区においても全麻 総数の約 60\%を占めた。疾患別構成(全麻総 数に占める各疾患頻度)を地区別にみると、北 勢、南勢、志摩地区ではほぼ同様の構成比率 であったが、中勢地区と紀州地区が対照的な 成續を示した。すなわち中勢地区は他地区に 比し胃癌が多く、胆石症が少なかつた。一方、 紀州地区では他地区に比し胃癌が少なく、大腸
瘭、胆石症が多かった(表 1 )。胃癌、大腸癌、 胆石症の発生率 (手術数/40 藏以上人口)の 地区別比較でも中勢地区、紀州地区で同様の 傾向が钼察された(図2)。

[結 語] 三重県下で、地理·産業·疫学的に 異なつた地域特性を有する5つの地区を選び、 消化器外科疾患の頻度を比較検討し、以下 の傾向が観察された。1) 北部/内陸部(蔍業 地区)では、平均寿命が高く、消化器外科疾 患では胃瘦が多く、大腸癌、胆石症が少ない。 2）南部/治岸部(漁業地区)では、平均寿命 が低く、大腸噟、胆石症が多く、胃癌が少ない。 地域に根ざした医療を行うには、診療圈の地域 特性を理解する必要があると考えられた。 [参考資料] 1)三重県勢要嗭 2)三重大学 第一外科関連施設集計 3)関連病院年報

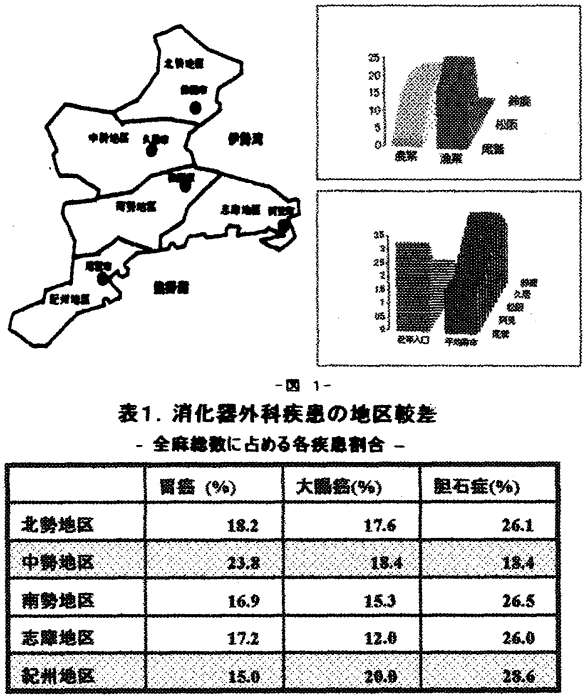

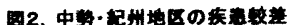

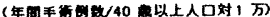

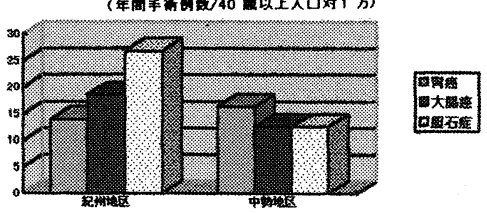




\section{D47 精神科入院中に発症した特異な䓵下性消化管異物による腸閉塞の一例}

\section{㜊藤六温さいとうむつお}

新舅渠厚生連刚羽郡総合病院外科

杉本不二雄植木医石嚗大坂田絊

\section{䓵下性消化管異物 腸閉塞症 精神分裂病患者}

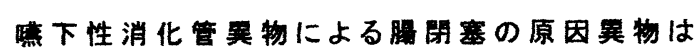
食慨性が大部分である。今回我々は精神科に

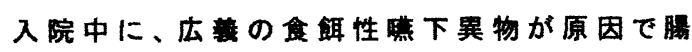

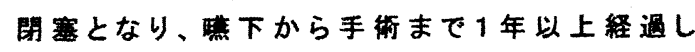
たと思われる应例を経験したので報告する。

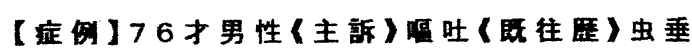
切除街 (時期不明) 57 才(1980年)精神分 裂病、知能造延にて当院精神科に入院。

(現病歴)精神科入院中、平成10年11月6日 午前 3 時䕎吐出現。11月7日当科に紹介され

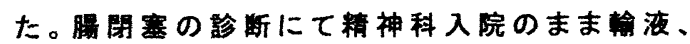
大建中疃、纊下剂による約2ヶ月半の保存的治 療で症状は鈘快した。周内視䗷検查、注灀透 視捦查では異常所胃は篮かった。

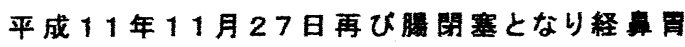
管を留置し、禁食、制液にて治璂したが症状軽 快せず12月6日当科人紹介され12月10日転 科した。(䡚科時理学所見〉腹部は平坦で柔ら

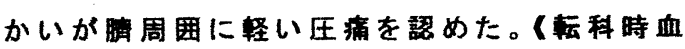
花生化学模查) WBC14500, Na124.8mEq/I、CI86.

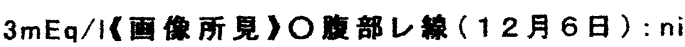

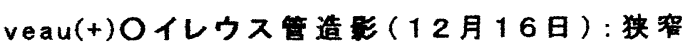

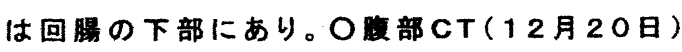

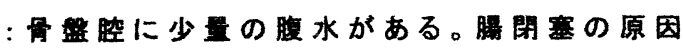
は不明。O注雷透視 (12月21日): 異常所見

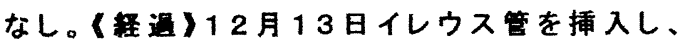
中心棦眽栄意法のもと保存的に治瘦を行った。 しかしイレウス䇫からの排液量は2週間以上も 大量であり(最高 $3200 \mathrm{ml} /$ 日)灀閉塞状態

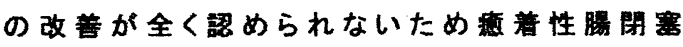

症の診断で12月27日手術を施行した。 〈手街所見〉腈管等の寉着はなかったった。Bau

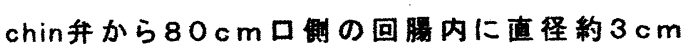
の球形の固い異物がありそれから30 cm口制 にイレウス管の先端があった。翼物から口僋の

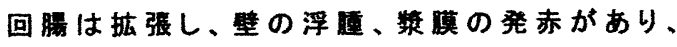
また買物の50 cm口側付近には霞管に接した 腈間膜に陳旧性の炎症性肥厚が 2 カ所に㒛め られた。縢閉塞の原因は異物と判断し用手的 にその翼物を肛門溉へ移動させたが横行結膆 でつかえたため同部で得管を切開し買物を䟻 去した。異物は变色したゴムに包まれた羊部で あった。術後第 21 病日精神科人転科した。

【まとめ】1)啨神科入院中、76才男性の球形 のゴムに包まれた羊率(直径約 $3 \mathrm{~cm}$ )に因る

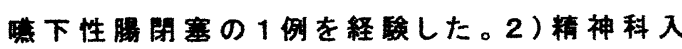
院费者の腈閉寒症には監下性も十分考虑に入

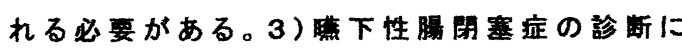
は消化管造影、膄部 CT 検査が有用であるが、 見落としを防ぐにはこのような疾患が少数では あるが存在することを考虑に入れた上での診 断が重要である。*本症例では術後の画像梌

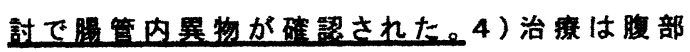
症状が轻い場合は保存的治挜が第一選択であ るが、いつまでも備閉塞が解除されなかったり、 異物が消化されにくいものであったり、腹部症 状が強かったり、消化管穿孔が暴われた碃合 には早急に堋腹手術が必要である。なお今後 は腹脭镜による腹腔内の锶察がより有効な晾 断の手段としてなりうるであろう。 


\section{D48 精神疾患患者における外科治療の臨床的検討}

\section{長谷川正和（はせがわまさかず）}

$\mathrm{JA}$ 杤木厚生連下都賀総合病院外科

中鴧和恵, 川村 功, 山崎一馬, 児玉多曜, 森川丘道, 金子健太郎, 飛田浩司, 堀部大輔

精神疾患、外科治療

精神疾患を有する患者は病気の発見が遅 れると共に、抗精神薬の副作用や術後の異常 行動などにより周術期管理に難渋する場合が 多い。当科では精神科を通じてこのような患 者を紹介される機会が多いことから、今回過 去 3 年間に当科で手術を施行した精神疾患を 有する症例について検討した。

対象は 17 例で、平均年齢は 63 歳、平均外 科在院日数は 47 日で一般患者と比較して著 明な延長はなかった。精神疾患の内訳は、う つ病、分裂病、痴呆の順に多かった。外科疾 患では胃癌、大腸癌などの進行消化器癌が 10 例であり、虫垂炎、胆囊炎などその他の疾患 が 7 例であった。また、緊急手術は 4 例であ った。

インフォームドコンセントは患者の意思 疎通性が良好な場合には本人より得たが、不 良な場合には家族構成や環境を考慮して最も 相応しい人物より得た。最終的な治療方針の 決定は面接を繰り返し理解が得られた上でな されたが、苦慮する症例が多かった。術前に は低栄養状態が多かった。消化器癌手術に際 しては、根治性もさることながら安全性をよ り重視する傾向であった。緊急症例では所見 が得にくく、手術適応の決定に苦慮した。術 中および術後の合併症に致命的なものはなか ったが、発生率は約 70\% と高率でうつ病の悪 化、イレウス、無動など精神疾患に特有なも のが多かった。特に、重症精神疾患に多い傾 向であった。補液ルート、ドレナージチュー
ブ、導尿チューブなどの自己抜去は頻回に認 められた。

以上、精神疾患を有する患者の外科治療に つい検討し以下の結論を得た。当科におけ る精神疾患を有する患者の外科手術は、合併 症は多かったものの致命的にはいたらず、ほ ぼ目的を達成できた。説明と同意を得ること が時に困難で、安全性を重視した術式の選択 となる事が多かった。緊急手術においては手 術のタイミングを逸しない事が重要である。 周術期管理には精神科とのきめ細かい連携が 必要である。 


\section{小児科疾患}

2D49 後腹膜血腫を伴った副腎腫媓の 1 例

水谷直樹（みずたになおき）

愛北病院小児科、同外科 $\%$ （愛知）

露木ますみ、山本直樹、金光幸秀※、浅井秀司※、 滝茂実※、黒田博文※、

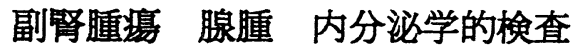

緒言 : 小児における副腎腫塲はまれであり、 内分泌学的に異常を示すことも多い。今回我

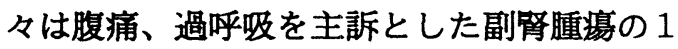
例を経験し、貧血が急速に進行したため、緊 急手術を施行し、手術前後の内分泌学的变化 を検討する機会を得たので報告する。

症例 : 患児は 15 歳女児。出生歴、既往歴 に特記すべき事項はない。家族歷では、両親、 妹ともに健康。平成 12 年 3 月 22 日、㷌宅 後突然腰痛、下腹部痛、手足がしびれる、息 苦しいなどの症状を呈し、当院救急外来を受 診、呼吸は非常に速く、血液ガス分析で $\mathrm{PO}_{2}$ の上昇、 $\mathrm{PC} \mathrm{O}_{2}$ の低下と異常を認め、過換気 症候群の疑いで入院となった。入院後も腹痛 は持続し、貧血が進行したため、腹部エコー、 腹部C $\mathrm{T}$ 等の検査を施行した結果、左腎上部 に巨大な腫敂を認め、腹水もあり、左副腎腫 诲破裂を疑い外科に転科、緊急手術となった。 上腹部正中切開にてアプローチし、腹腔内 に約 $1200 \mathrm{~m} 1$ の大量出血ならびに広範囲の後 腹膜血腫を認めた。腫哣は膵䑏の背面、左督 上部に確認され、厷範な後腹膜血腫に取り囲 まれるように存在していた。腫崵の大きさは $8 \times 9 \mathrm{~cm}$ 、重量 $500 \mathrm{~g}$ と巨大で、周囲の 組樴から剥離した後、脾䑏とともに摘出した。 手術時に磼認できた両側卵巣は正常大で、子 宮は年跉に比してやや未熟であった。腫寚は 組織学的に腺腫で割面にも血腫を認めた。

術後、ステロイド、アスピリンの投与を行 なったが、経過が順調であったため漸隇した。
内分泌学的㭘討 : 患児は 12 歳頃生理が $2 \sim 3$ 回あったがその後全くなく、声は低く また全身男性型多毛で、クッシング症候群な どを疑い、内分泌学的検討を行なった。術前 検査は十分に実施できなかったが、電解質で はカリウムがやや低值以外特別な異常はなく L H、F S H、A C TH、カテコールアミン 分画、血中コルチゾール、アルドステロン、 アンドロステロン、テストステロン、レニン 活性、尿中VMA、HVA、1 7-K S、 17-OHC Sなどの内分泌学的検查も正常 であった。

術後に行なった上記の内分泌学的検査、更 に尿中 1 7-OHC S の日内変動、 L H R H 負荷試験、デキサメサゾン抑制試験、迅 速 A C T H試験なども正常であった。

考案 : 副腎腺腫は進行が速く、多毛症も少 なく、尿中 1 7-OHC S、血中コルチゾー ルは増加する事が多いとされるが、本例では 各種内分泌学的検查の結果から、右側副惄機 能は正常であると考えられ、男性型多毛症、 生理の消失などの原因は不明であった。腺腫 は急速に腫大し、外傷などの既往なく出血し たと考えられ、自然破裂の大きさの限界を知 る意味でも興味深い症例と思われた。今後の 経過を注意深く観察していく予定である。 


\title{
2D50 超音波検査法が有用であった幼児 AGML の 2 例
}

\author{
橋本英久、西田知弘、三輪正治、野田秀樹 \\ 今井信輔、後藤 博、今村裕司、吉村 一
}

\section{(AGML - 高分解能探触子 - Helicobacter pylori)}

〔はじめに〕

消化管疾患における体外式超音波検査の有用性 に関する報告はこれまでに数多く認められる。 超音波技術の進歩に伴う空間分解能に優れた探 触子により表在診断は飛躍的に伸びている。当 院ではこの探触子を腹部消化管に利用し良好な 結果を得ている。今回我々は幼児 AGML 2 例 を経験したので報告する。

〔使用装置ならびに診断手順〕

使用装置は東芝製 SSA-250A $3.75 \mathrm{MHz}$ コン ベックス型探触子・ $7.5 \mathrm{MHz}$ アニュラアレイ高分 解能探触子で腹部をコンベックス型探触子でル 一チン検索をしその後高分解能探触子にて消化 管を系統的に操作する。前処置は必要としない。

\section{[症例 1 ]}

患 児: H・M 1 歳 3 ヶ月 男児

主 訴：食欲、活動低下

家族歴：特に異常なし

既往歴：特になし

現病歴：寝起き後食欲、活動低下を認め表情も 乏しい為小児科受診

入院時現症：体重 $7400 \mathrm{~g}$ - 脈拍 90 回/分 - 体温 $37.2^{\circ} \mathrm{C}$ ・顔色不良・結膜貿血認めず・腹部所見 認めず

入院時検査所見 : 便潜血陽性・腹部単純写真異 常認めず・腹部超音波検査にて胃壁の異常肥厚 像を認める。末梢血検查にて貧血を認める。

入院後経過：胃内視鏡検査にて胃前庭部後壁に 昜出血性の潰瘍を認女周囲浮腫状変化、出血性 ビランも認められた。薬骫投与後 6 日目の腹部 超音波検査にて胃壁の肥厚像は消失した。

[症例 2]

患 児: $\mathrm{R} \cdot \mathrm{T} 1$ 歳 2 ケ月 男児

主 訴：嘔吐、顔色不良

家族歴：特に異常なし

既往歴：特になし

現病歴：嘔吐、顔色不良にて小児科受診、浣腸
にてタール便を認める。

入院時現症：体重 $7400 \mathrm{~g} \cdot$ 脈拍 162 回/分 - 体温 $38^{\circ} \mathrm{C}$ ・顔色不良・結膜に貧血を認める。腹部所 見は認めず。

入院時検査所見：便潜血腸性・腹部単純写真異 常認めず・腹部超音波検査にて胃壁の異常肥厚 像を認め、潰瘍を示唆する画像所見を認める。 末梢血検査にて貧血を認める。

入院後経過：胃内視鏡検査にて胃前庭部に白苔 を有する潰瘍を 2 個所認めまた、線状潰瘍、周 囲浮腫状変化も認めた。薬剤投与後10日目の腹 部超音波検査にて胃壁の肥厚像は消失した。

\section{〔考案]}

今回我々は顔色不良、嘔吐、食欲低下、活動低下 を主訴に当院小児科を受診腹部超音波検査にて 胃壁の肥厚を認めAGML と診断、胃内視鏡検査 にて胃潰瘍を認め胃生検標本にて Helicobacter pylori を認めた症例を報告した。消化性潰瘍は、 多くは成人に発生する疾患であるが最近の複雑 な環境によるストレスから発生年秢は低下し 1974年頃より小児胃潰瘍は、急激な増加を示し ている。臨床症状の特徴では腹痛が最も高頻度 ではあるが幼小児においては本症例のように顔 色不良、嘔吐、食欲低下、活動低下など腹痛を 訴える事のない、また自身で症状を訴える事の できない場合診断は困難となる。小児胃潰瘍は ストレス関与の高い疾患であることはよく知ら れているが精神的ストレスと確認できる下限年秢 は $6 〜 7$ 歳であり本症例においてはストレスの 関与は不明であったが、胃内視鏡検査時胃生検 標本 PCR 法、顕微鏡にて Helicobacter pyloriが 検出された以外原因ははっきりせず Helicobacter pyloriの感染が関係あるものと考えられた。早 期診断が可能であった本症例のように自覚症状 の乏しい診断に苦虑する乳幼児への上腹部超音 波検查は高分解能探触子により肥厚性幽門狭窄 症と並び AGMLへのファーストチョイスとして 一層の利用が期待される。 
2D51 小児救急医療における地域中核病院の役割

\author{
渡部誠一 \\ 土浦協同病院小児科 \\ 渡辺章充，福田睦夫
}

小児救急医療，地域急患センター，小児 ICU

【緒言】現在我が国は深刻な少子化の問題に 直面し，育児支援として小児救急医療の充実 が求められている.「地域中核病院の小児科 として，地域医療に貢献する」という目的の 元に，当院では 24 時間小児科単独当直を行 ってきた．その現状と問題点を示す．

【方法】当院小児科救急外来の現状, 茨城 県内の小児初期救急の調査結果, 当院小児 ICUの現状についてまとめ, 問題点を整理 し, 小児救急医療の今後のあり方について 考察する.

【結果】1998 年 1 年間の小児科救急外来患 者 11714 名を分析した. 年齢は 0 2 歳が $44.5 \%, 0 \sim 6$ 歳が $75.5 \%$ と低年齢が多く， 乳幼児が特に病院へ集中する. 初期救急の 比率が平均 $89 \%$ と高い. 17 時から 22 時 までの 5 時間に夜間（17 時から 8 時）受診 者の $59.8 \%$ が来院している. 一方深夜帯に は小児科医がいる病院が少ないために更に 広域から集中する。

茨城県は県北・県央・県南・県西・鹿行 5 地域， 14 郡，85 市町村からなる人口 300 万 人の縦長の県で, 当院は県南の土浦市に位置 している. 小児科救急外来の受診患者の居住 地をみると県南・鹿行 2 地域を含む，対象人 ロ 60〜70 万人の医療圈で, 成人に比べて小 児では医療圈が広域化している。

当初上気道炎, 胃腸炎や熱性けいれんと 思われたが後に急速に進行して脳炎脳症, 心筋炎等であった例がある. 乳幼児は予備 カが少なく症状がそしいため早期に鑑別す
ることは難しい。

茨城県内の調查では 365 日夜間診療を実 施している休日夜間急患センターは3 施設, 9 市町村と全県 85 市町村の 10.6\%にすぎず, 残りの 74 市町村 (89.4\%) は周辺の二次三 次救急施設に依存している．現在小児科医 が深夜帯も初期救急を行っているのは県内 では 2 施設のみである.

県内の小児科医は 223 名で，人口 10 万対 小児科医師数は 7.5 名（全国平均は 10.9 名） と全国で 2 番目に少ない.

当院では小児 ICU5 床と中央 ICU に約 2 床の小児が入室できる．1997〜98 年の 2 年間に 225 名が入室し, 人工換気を 95 名で 行った. 一日平均在室人数は 7.4 名で 疾患 は神経疾患, 心疾患, 呼吸器疾患)が多く, その他に腎疾患（透析）や児童虐待も見られ た. 三次医療を行いながらも初期救急外来 をストップすることはできない. 周辺に小 児ICUが少なく，極力受けざるを得ない。

【考察】小児救急医療のニーズは增大し, 地 域中核病院への集中は自然の流れであり，初 期から三次医療までの質の高い医療を求めら れている.しかし小児科医は滅少していく現 状がある. 今回の検討結果と近年の情報 ・ 交通網の発達を考え併せると，広域の地域 急患センターが小児救急医療では望ましく， そのためマンパワーの確保と地域ネットワー クがこれからの方向性と考える. そしてわれ われ地域中核病院がその中心的役割を果たす ことになると思う. 


\title{
寄 生 虫
}

2 D52 蠅蛆症（myiasis）を併った糖尿病性壊痽の 1 例

\author{
酒井浩志（さかいひろし） \\ 揖斐総合病院 整形外科 \\ 渡辺友純 熊沢慎志
}

\section{蠅蛆症、糖尿病、糖尿病性壊瘨}

患者は 6 1 才、男性でH 9.11 月当院内科

で糖尿病指摘されるも放置していた。 H 11 .

5 月 24 日、近所の人が患者宅を訪問した時、

異臭に気付き救急車で来院す。入院時現症と

して、3 $8^{\circ} \mathrm{C}$ 以上の熱発があり、右足は異臭 を併い、特に第 1 趾の壊疽が強く、多数の蠅 幼虫が寄生していたので直ちに洗浄、デブリ ッドメントを行なった。入院時検査所見とし て、白血球 $34600 / \mathrm{mm}^{3} 、$ C R P 35.2、血糖 $341 \mathrm{mg} / \mathrm{dl}$ であった。翌日、右母趾切除、5 月 27 日、右下腿切除術を施行した。以後経 過は良好で、感染症状は消失し、糖尿病もイ ンシュリンによりコントロールされた。この 患者は、一人暮らしであり、糖尿病性網膜症 による視力低下（㡺間何とかわかる状態）、 糖尿病性の未梢神経障害による足関節以下の 温痛鸴消失がある為、発見される 1 ケ月位前 にはほとんど誛たきり状態で、寝ていた部屋 のフトンの周囲で排泄を行なっていた。この 為、壊疽部に蠅がとまり、蠅蛆症を合併した と考えられる。myiasis の発表は戦前には多 数認められたが、近年になって隇少し、特に 糖尿病性壊疽に合併した症例は、1988. 石井 ら、1990. 高木らの発表に次いで本邦では 3 例目であった。今回の場合は、特殊な環境や 患者個人の合併症が重なり、発見が遅れたの が蠅蛆症の一因と考えられた。 
○米山敏美 A. Erdembileg 塩飽邦憲 山根洋右（島根医大環境保健） 寄生虫症、日本海裂頭条虫症、マンソン孤虫症

【はじめに】近年、新興・再興感染症と して、人体寄生裂頭条虫症が注目されて いる。我々は、日本におけるこれらの裂 頭条虫症の症例報告検索を行い実態を把 握するとともに、我々の経験症例も含め て、その対策を考察したので報告する。 【対象と方法】医学中央雑誌をコアに 1998 年までの症例報告を検索し、その論文内 容を解析した。

【結果と考察】1998 年までに 9 種類の裂 頭条虫類の感染が報告されている。

1.日本海裂頭条虫症は、1727 症例で男 女比は約 3:1 で 20-50 才代、農業、商業、 児童・学生に多い。1970 年代から增加し、 症状は、自然排出、下痢・軟便、腹痛が 多く、感染源はサクラマスである。 2 . 大複殖門条虫条虫症は、266 例で男

年代別日本海裂頭条虫症報告数

(1903 1998年)

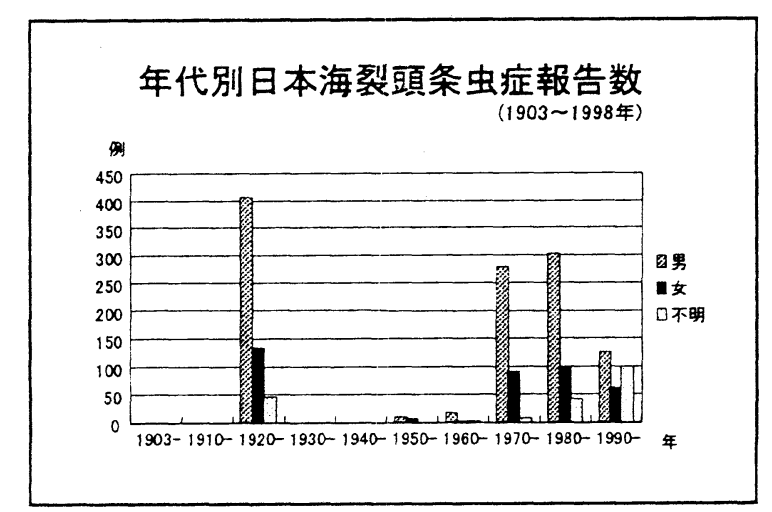

女比は 9:1 で、30-60 才代、漁業、農業、 会社員に多い。1960 年代から增加し、症 状は、虫体排出、下痢・軟便、腹痛が多 く、推定感染源はイワシ、カツオ、アジ、 サバなどである。

3. マンソン孤虫症は、418 例で男女比 は 1.4:1 で、20-60 才代に多く、1960 年代 から增加している。症状は、腹部、大腿 部、乳房などの迷入、腫瘤形成である。 推定感染源は、ヘヒ、カエル、ニワトリ などの生食による。

対策としては、グルメ志向、下手物食 いなどの飽食文化の社会背景に対し、消 費者への健康学習強化、第一線医家への 情報提供、国内・国際的情報収集ネット ワークの構築が緊要な課題となっている。

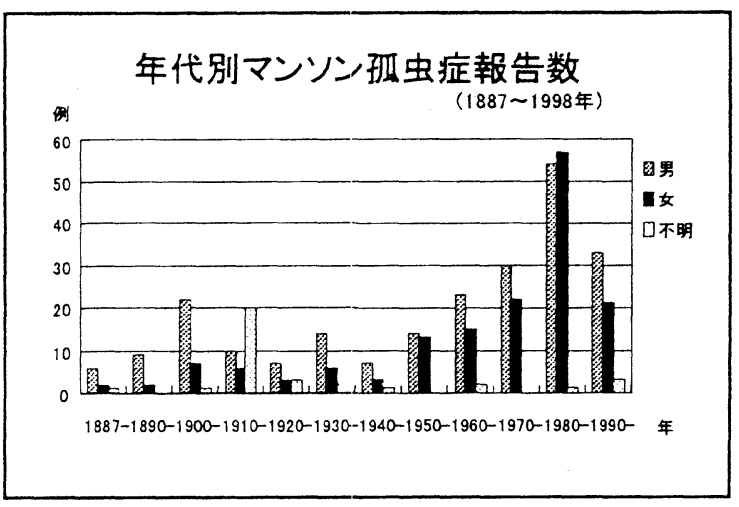


2D54 長野県佐久地方におけるマダニ刺咬症とライム病の臨床疫学的研究（第 2 報）

\author{
堀内信之 (ホリウチノブユキ) \\ 長野県厚生連佐久総合病院 皮膚科
}

マダニ刺咬症 ライム病

くはじめに>マダ二刺咬症は、本邦の農山村 地域において十余年前までは、一般的な虫刺 症のひとつとして扱われていたにすぎなかっ た。

ところが、1977 年に米国コネチカット州 ライム地方で、マダニによって媒介される新 しい感染症「ライム病」が発見され、その後 本症が世界各地で相次いで確認されるに及ん で国際的な関心を集めるようになった。

ライム病は、病原体であるライム病ボレリ

ア (Borrelia burgdorferi)がマダ二刺咬 によって感染し皮膚、神経、心臓関節など 全身が侵される全身性感染症である。
本邦においては、1987 年長野県妙高高原 で刺咬を受けた患者より初発症例が報告され て以来、全国各地で本症例が確認され，本邦 における特徵も明らかにされつつある。

我々も第 40 回日本農村医学会総会 (旭川 市）において、第一報として報告し農山村地 域の新しい感染症として実態を調查していく 必要性を提起したが、今回その後に経験した ライム病症例を中心にして、本邦におけるラ イム病の特徵について報告する。

《調查結果と考察>

\section{(1) 外来受診者数}

1974 年から 1999 年までの 26 年間に、 佐久総合病院を受診したマダ二刺咬症患者は 男 84 例、女 81 例であった。受診時の状態は、 虫体を咬着させたまま受診した症例 62 例 (37.6\%)、虫体を自分又は家人が除去した後 に受診した症例 79 例 (47.9\%)、虫体を除去 した後に遊走性紅班が出現したために受診し
た症例 16 例 (9.7\%)、その他 8 例 (4.8\%) となった。

\section{(2) 年令別外来患者数}

10 歳未満の子供が 33 例と最も多く、50歳 台 32 例、60歳台 29 例、40 歳台 23 例となっ た。

（3）刺咬を受けた月

6 月 67 例、 7 月 52 例、 5 月 29 例とこの 3 ケ月に集中していた。

（4）刺咬時の症状

刺咬後から外来受診時までの症状としては、 小紅班（直径 $5 \mathrm{~cm}$ 末満）102 例、特に症状の ないもの 23 例、疼痛 18 例、硬結 17 例、遊 走性紅班 16 例が多いものであった。

（5）刺咬部位

背部 25 例、腹部 22 例、胸部 19 例、頝部 下肢 16 例などが多いものであった。

\section{（6）マダ二の除去法}

医師にて切開又は切除したもの 56 例、自 分又は家人がつまみ取ったもの 94 例、自然 脱落 7例となった。

（7）刺咬マダニの種名 シュルツエマダニ 56 例、ヤマトマダニ 26 例、その他 3 例となった。

\section{（8）ライム病自験例}

男 10 例、女 6 例を経験した。 〈結語〉本邦のライム病の特徵は軽症例が 多く、第 1 期遊走性紅班の発症に留まる症例 が大部分である。本邦のライム病の分離株は 病原性が弱い、Borrelia garinii が大部分 である。本人が虫体を除去した後に発症する 例が多い。 
小林ひ气苍”、矢尾明美、大西昌子、宮田孝幸 平野 均、駒田洋子、瀬古 義雄、石原 明徳

(厚生連 松阪中央総合病院 臨床検査科)

マンソン住血吸虫 集卵法好酸球

【はじめに】マンソン住血吸虫は、成虫が人 体に寄生する吸虫類で血管寄生吸虫類の一種 であり、アフリカ、南米を中心に分布してい る。体内に侵入すると門脈に寄生し、腸壁、 肝、肺、脾に病害を及ぼす。急性期には粘血 下痢便、全身倦急感、食欲不振、発熱、肝腫 大がみられ、慢性期には貧血、肝硬変、脾種 がみられる。

今回我々は便中にマンソン住血吸虫卵を認 めた症例について経験したので報告する。

【症例】 64 才男性。1998 年 11 月末から 12 月初旬にかけて、アフリカのケニア奥地へ渡 航。その際ビクトリア湖付近の沼で足から膝 までを水につかる儀式右行なった。帰国後、

胸焼け、背部痛、関節痛、下痢、腹痛および 39 度台の発熱を認め、1999 年 2 月初旬、近 医受診。好酸球増多を指摘され、当院紹介入 院となった。

【検查所見】入院時検查所見（表 1 ）は軽度 の肝機能障害と、白血球、好酸球の増加等の 炎症反応が認められた。また、大腸内視鏡で は、S 状結腸を中心として結腸全体の粘膜に 黄白色の顆粒状隆起を多数認称、組織生検で 粘膜内に多数の虫卵が確認された。 便集卵法（MGL法）により、便中より少数 のマンソン住血吸蜺が検出され、マンソン 住血吸虫症と診断された。診断確定後、プラ
ジカンテルを投与し、投与開始後約一週間で、 便中虫卵は陰性化した。

【虫卵の形態的特徵】長径 $114 \sim 175 \mu \mathrm{m} \times$ 短径 45〜 $68 \mu \mathrm{m}$ の長楕円形で小蓋をもたず、 卵殸は比較的薄く、側方に長い一本の棘を持 つ。

【まとめ】近年、海外への渡航者は年々増加 し、感染の機会が多くなると思われる。輸入 感染症に関する最新の知識を習得するととも に、消化器症状を訴える患者には、渡航歷及 び好酸球等の臨床的背景を考慮し、集卵検査 （MG L法）を実施する必要があると思われ る。

\begin{tabular}{|c|c|c|c|c|c|c|c|c|c|c|c|}
\hline & TP & & & & WBC & 236 & $6 \mid 10^{3} / \mu$ & & 比重 & 1.030 & \\
\hline & ALE & 3.9 & Bat & & SBC & 4.40 & & & & 50 & \\
\hline & ZTT & 7.6 & & & $\mathrm{Hb}$ & 13.7 & $7 / \mathrm{g} / \mathrm{dl}$ & & 墰白 & (-) NEG & \\
\hline & TBiL & 0.4 & $\mathrm{mg} / \mathrm{dl}$ & & $\mathrm{Ht}$ & 41.0 & 8 & & 裾 & $(-)$ NEG & \\
\hline 生 & AST & 24 & IU/1 & 血 & PLT & 362 & $210^{3} / \mu$ & 1- & 穈血 & (+) 25 & \\
\hline & ALT & 105 & IU $/ \mathrm{I}$ & & & & & & & & \\
\hline & ALP & 509 & IU/I & & Baso & 3.0 & $s$ & & 白血球 & 1未満 & HPF \\
\hline 化 & $r$ GTP & 59 & IU/I & & Eosino & 61.5 & $x$ & & 赤血球 & & /HPF \\
\hline & che & 0.57 & $\triangle \mathrm{PH}$ & 液 & Stab & 1.0 & $x$ & 般 & 倔平上皮 & $1 \sim 4$ & HPF \\
\hline & Tcho & 125 & $\mathrm{mg} / \mathrm{d}$ & & & 26.0 & s & & & & \\
\hline 学 & $\mathrm{Na}$ & 139 & $\mathrm{mEq} /$ & & Lympho & 4.0 & 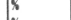 & & 便虫舆 & & \\
\hline & k & 4.7 & $\mathrm{mEq} /$ & & Mono & 2.0 & s & & 涯抹法 & $(-)$ & \\
\hline & C। & 99 & $\mathrm{mEa}$ & 椮 & A-Lympd & 2.0 & $x$ & 㛟 & & & \\
\hline 検 & $\mathrm{Ca}$ & 9.4 & $\mathrm{mg} / \mathrm{d}$ & & Myel & 0.5 & $x^{x}$ & & & & \\
\hline & IP & 3.0 & $\mathrm{mg} / \mathrm{dl}$ & & & & & & & & \\
\hline 查 & UN & $\begin{array}{r}17 \\
101\end{array}$ & $\mathrm{mg} / \mathrm{d}$ & & $\begin{array}{l}P T \\
\text { INR }\end{array}$ & & & & & & \\
\hline & $\begin{array}{l}\text { CRE } \\
\text { UA }\end{array}$ & 9.0 & $\begin{array}{l}\mathrm{mg} / \mathrm{d} \\
\mathrm{mg} / \mathrm{d} \text { l }\end{array}$ & 角 & APTT & $\begin{array}{l}1.09 \\
37.2\end{array}$ & 秒 & 五 & & & \\
\hline & AMY & 60 & $10 / 1$ & & ESR & & & & & & \\
\hline & CRP & 3.4 & $\mathrm{mg} / \mathrm{d}$ & & 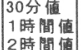 & & $\begin{array}{l}\mathrm{mm} \\
\mathrm{mm} \\
\mathrm{mm}\end{array}$ & & & & \\
\hline
\end{tabular}

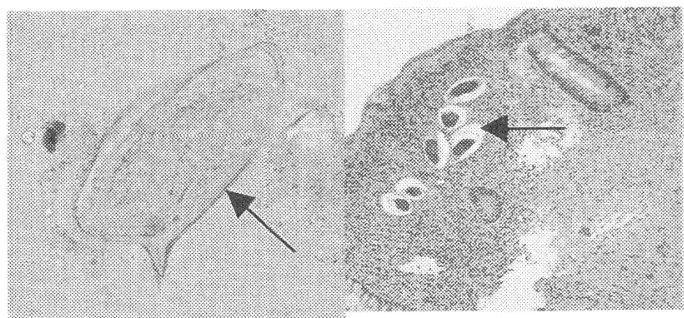

アッリ住血吸虫卵組織内虫卵 


\section{精神疾患}

2D56

共同住居開設にかかわって

〜自立への援助〜

篠原智美 (シノハラトモミ)

長野県厚生連佐久総合病院 精神科西二階

畑美枝

自立支援・共同住居

\section{1. はじめに}

精神障害者は、病院収容の時代から精神保 健福祉法の変更により、地域で生活を支える 体制が求められている。しかし、退院できず にいる人々が今もって多いのが現実である。 今回、病状が安定しても自宅への退院が困難 な長期入院患者を受け持った。共同住居設立 から入居まで患者さん、家族、地域の人々と の関わりを通し、地域で暮らしていくための 援助を考えたのでここに報告する。

\section{2. 研究目的}

共同住居開設から入居まで患者さん、家族、 地域の人々との関わりを通し、精神障害者が 地域で暮らすために必要な支援を考える。

\section{3. 研究方法}

二人の生活準備から設立に必要な条件、住 むための生活訓練、生活を支える工夫を考え る。

\section{4. 結果、考察}

設立には、地域住民の反対によりせっかく の共同住居がつぶれた事もあり、ケースワー カー中心に家族会、ボランティア、保健婦の 協力を固め、やっと共同住居を手に入れるこ とができた。共同生活へ入居するには生活を 維持し、病状の安定をはかることが重要とな る。

病状の安定をはかるため、

(1) 急薬を防ぐための投薬カレンダーの使用

(2) 健康の維持をはかるための自炊の訓練

(3) 掃除、洗䍜、買い物を行い、生活の訓練 をし、通所方法を考える
(4) 日中、デイケア使用し、生活のリズムを つくる

以上の(1)か(4)を二人と共に入院中から外泊 の練習をし、生活の準備を絽り返してきた。 退院後は訪問看護や、地域の保健婦の訪問で 継続したケアを行い、病状の安定をはかって いる。また、孤立的な K氏と協調性のある $\mathrm{O}$ 氏という異質の二人だが、看護婦、地域 の保健婦やボランティア、家族会、家族との 触れ合い、そしてお互いの存在が二人の生活 の支えになっていると考える。

病状が安定しているのに長期入院を余儀なく されている精神障害者が、退院して生き生き と生活できるように、又、第二第三の共同住 居がふえるよう、今後この学びを生かしてい きたい。 
2D57 郡部内科診療所における軽症うつ病とその治療

増村 道雄（ますむら みちお）

医療法人社団 増村医院

精神疾患、柽症うつ病

<目的>最近の報告では、一般診療科を受診 する患者のうち約 $20 \%$ 蔳神科的な問題を 抱えている 1)といわれている。又、日本のう つ病患者は全人口の 3ー5\%と推測されてお り2)、特に柽症のうつ病患者の增加と、それ に伴う一般内科を受診する軽症うつ病患者 の增加が指摘されている。（1）,2）：W.H.O. 1995)

農村部での精神科疾患の実態を評価する 目的で、郡部内科診療所における精神疾患患 者及び軽症うつ病患者の動向を分析し、それ らの治療上の問題点について検郡を加えた。 <対象及び方法>1998 年 2 月より 2000 年 3 月までの 2 年 2 ヶ月間に、兵庫県加東郡の一 内科・周外科診㞠所を受診した外来患者を対 象として、各月毎にうつ病患者及び精神疾患 患者の、外来患者実人数に対する比率を算出 し、期間全体でのそれぞれの動向について検 討した。診断は I C D-10を使用した。

<結果 > (1)疾病分類、年龄別・男女比 : 1999 年 2 月の疾病分類では、うつ病 58 人、気分 障害 25 人、不安障害 27 人、心気障害 3 人、 身体表現性障害 63 人、身体表現性疼痛障害 患者 4 人、睡眠障害 13 人であった。男女比 は男性 61 名 $31 \%$ 、女性 133 名 $69 \%$ であっ た。男性は30才台と60才台にピークがあり、 女性は 30 才台から 70 才台まで、広い年令層 に分布している傾向がみられた。

(2)期間内での精神疾患患者の全外来患者に 対する割合は、'98 年 2 月 94 人 $8.3 \% 、 ' 99$
年 2 月 195 人 $16.9 \% 、 7$ 月 270 人 $23.9 \% 、{ }^{\prime} 00$ 年 2 月 295 人 $22.9 \%$ 、と年々增加傾向をみ とめた。一方うつ病患者の全外来患者に対す 万割合は' 98 年 2 月 14 人 $1.2 \% 、 ’ 9$ 年 2 月 58 人 $5.0 \% 、 7$ 月 53 人 $4.7 \% 、, 00$ 年 2 月 56 人 $4.3 \%$ であった。

〈考察〉農村部の内科診療所においても、こ の 2 年間に精神科的問題を抱える患者受診 が增加の一途にある。增加の要因は、構造不 況のような社会的要因と、このような病態を 治療してゆくと言う診療側の考え方が地域 で理解されてきた、という医療技術の社会的 評価という2つがあると考えている。 <結論>1) 郡部内科診療所においても精神 科的な問題を抱える外来患者、うつ病患者は 增加している。

2）疾患の存在、症状、治療法、予後につい て患者本人、家族のみならず、広く地域住民 への啓蒙が必要である。

3）治療上、(1)患者のプライバシーの保護、 (2)専門家への紹介時期の判断が肝要である。 4）一般診療科外来担当医の、精神科疾患の 理解が、農村部においても今後一層必要にな ってくると考えられる。 
2D58 青年期での長期入院における心理過程の援助

ーフィンクの危機モデルを用いてー

岡崎史恵（オカザキフミエ）

岐阜厚生連昭和病院看護部

山下道子・名倉冶代 ·渡辺静代

フィンクの危機モデル・青年期・慢性疾患

[はじめに

今回 19 歳という多感な青年期に全身性エリ テマトーデス (以下S LEと略す) での入院を 余儀なくされ、生活環境の変化や様々な規制 を強いられる中、危機的状態となった患者の 心理過程をフィンクの危機モデルを用いて考 察してみたので報告する。

[患者紹介]

氏名 $M \cdot I 19$ 歳 女性 学生

入院期間1998年12１999年3月6日 診断名 SLE
家族構成 父、母、弟、妹の 5 人暮らし

現病歴・1997 年1 8 歳にて某病院で診断され たが、父親がステロイド療法を拒否し、他院で 漢方の治療を受けていた。1998 年8月 11 日 症状覀化し当病棟入院となる。

[看護の実際及び考察]

\section{1 ·衝撃の段階}

本患者は入院当初より泣いている姿がよく見 られたが、その理由について自ら話す事はな かった。私たちはこの時期そっと見守ること が彼女への最良のケアであると考え、患者の 声を聞くことに努力した。

$2 \cdot$ 防御的退行の段階

友人からの手紙に興奮したり、過呼吸を起こ したり、反抗的言葉などの不安定さを表現す る一方、年龄の近い看護婦にのみ心情を訴え ることが多く、情報の共有が困難になってき た。

そこで私達はカンファレンスを重ね、同世代
の看護婦から情報を得、統一した関わり方や 役割分担など検討してきた。

\section{$3 \cdot$ 承諾の段階}

この時期わがままを押し通そうとする態度が みられ、徐々にエスカレートしていったるそれ に対し、その都度時間をかけ、絽り返し話すこ とで同意を得られるようになった。

これは病状が落ち着きを見せてきた事もさる ことながら、それまでの医療者側の誠実な支 持が受け入れられたと考える。

\section{$4 \cdot$ 適応の段階}

この時期になると、安定した精神状態となり 感情のコントロールもつき、どの看護婦にも 同じ様に接する事が出来た。又、生活面でも、 工作を作り他者との関わりも増えた。これは、 患者が現実を受け入れ、今の自分に出来る楽 しみや人との関わりの大切さを気ずいた為と 考える。今回、我々はフィンクの理論を元に、 時に見守り、話を聞きそばに付き添い、その段 階に応じた援助を行ってきたが、我々の力以 上に彼女の周りの人的環境が、彼女の成長に 大きく関わり、その中で彼女は危機を脱して 行ったと考える。

[終わりに］

色機に対する反応は個々人によって異なるが、 フィンクの危機モデルは危機の構造とその考 え方を具体的に示している。その人にあった 看護介入を選択し、人的、時間的、物的などの 知識、経験を元に援助して行く事が、患者の危 機からの成長に大きく関与する事が分かった。 


\title{
医療倫理
}

\section{E01 高齢腎不全患者への透析導入の是非}

\author{
前田益孝（まえだよしたか） \\ 取手協同病院 内科 \\ 小林 隆彦、岡戸 丈和、椎貝 達夫
}

高齢、腎不全、透析導入

\section{【はじめに】}

透析導入患者の年齢は年々、高齢化してお り、80 歳以上の高齢で透析を開始する症例 も決して稀ではなくなってきた。そのような 高齢症例では、単に救命を目的とした透析の 導入は現実的でなく、対応に苦慮する場合も あり、症例を提示の上、検討した。

\section{【症例】}

(症例 1) 97 歳、女性。腎硬化症によると 思われる慢性腎不全のために外来加療中であ ったが、高窒素血症の進展女り、右前腕に内 シャントを造設し、血液透析を開始した。症 例は93歳の痴呆ある妹と二人暮しであり、 他の肉親である侽、姪らは遠方に在住してお り、日常生活の介助は公的サービス、隣人に より、なされていた。難聴はあるが、指示動 作に湑い、杖歩行も可能であった。本人は

「死にたくない」という意志を繰り返し、訴 えており、隣人が週 2 回の通院透析の送り迎 えを受け入れたため、維持透析の導入に踏み 切った。

(症例 2) 87 歳、男性。尿路結石症による 慢性腎不全のために外来加療中であったが、 鬱血性心不全を併発し、入院。本人は頑強に 透析を拒否したが、家族は救命を希望してお り、全身を拘束した上で、ダブル・ルーメン・ カテーテルを留置し、血液透析を開始したと ころ、全身状態は急速に改善した。本人は回 復後、「透析療法を何故、嫌がったのか、わか らない」と述懐した。

\section{【考察】}

高齢腎不全患者の透析導入に際しては、患 者本人の判断力に疑問があり、意志確認が困 難である、家族等の協力が必須である等の理 由から、透析療法の導入の是非に関し、苦慮 することが多い。また患者、その家族の生命 観の多様化、paternalism への批判から、主 治医の裁量権の範讲で決断することにも問題 がある。一般的には痴呆などのために透析療 法中に回路を自己抜去する可能性がある症例 や末期癌では透析を施行しないが、前述の症 例のように一律のコンセンサスのもとに決断 することも無理なようである。日本透析医学 会でも透析医へのグループ・インタビューか ら、高齢者への透析導入の是非に関し、問題 点をあげているが、判断基準の作成には至っ ていない(透析会誌 $31: 1221-5 ， 1998) 。$ 他施 設でも同様な症例を経験していることが予想 され、討論をお願いしたく、報告する。 


\section{$2 \mathrm{E} 02$ 脳死判定における $3 \mathrm{D}-\mathrm{C}$ T A の意義}

進藤健次郎

麻酔科

秋田県厚生連由利組合総合病院脳神経外科

菊地顕次、高橋巨※、須田良孝、山崎豊※、塩屋斉

脳死判定、臓器移植、3 D - C T A

本年 4 月 16 日、本邦第 6 例目となる脳死下 臓器提供症例を当院で経験した。患者さんは 40 才台の女性で、来院時、意識はJ C S300、 G C S 3、瞳孔散大、対光反射消失。血圧は 223〜 $142 \mathrm{~mm} \mathrm{Hg}$ 。自発呼吸は微弱でほとんど 停止しかけていた。人工呼吸器装着後施行し たC T検査で、くも膜下出血、左脳内血腫を 認め、ひきつづいて行った 3 D-CTA（3 non-filling で脳動脈瘤は描出できなかった。

(写真)
状態では動脈瘤の存在が証明できないわけで、 手術の可能性がなくなる。又、頭蓋内圧が方 進して脳血流が杜絶した状態では、いかなる 薬剂も脳に到達できず、その効果は期待でき ない訳で、もはやいかなる治療も存在せず保 存的治療のみ行われる事となる。

以上のような事から、脳死下での臟器移植 に際して 3 D-C T Aでの non-filling 現象の 証明は重要な参考所見になると考えられた。

以上の所見から、この患者さんには手術を ふくめ積極的治療はもはや行えないと判断し、 人工呼吸器装着下、保存的に治療した。

孡和 61 年 1 月、厚生省の脳死判定基华 (竹 内基準）が作られた際、脳血管撮影による non-filling 現象が、判定基準の一つとしてとり あげられたが侵襲的であるという理由等で採 用されなかった経緯があった。以来 15 年。 C T 検査技術の進歩により $3 \mathrm{D}-\mathrm{CT}$ T Aよ る診断が一般化した現在、本法による脳血流 杜絶の証明は脳死の重要な参考所見となると 考えられた。

救急医療の視点から、脳死と判定された患 者さんに充分な医療がなされたかという点が 検証される事になる。脳死となる患者さんの 中で最も頻度の多いと考えられるくも膜下出 血の患者さんでは手術を行うには脳動脈瘤の 存在診断が必須となる。しかし non-filling の

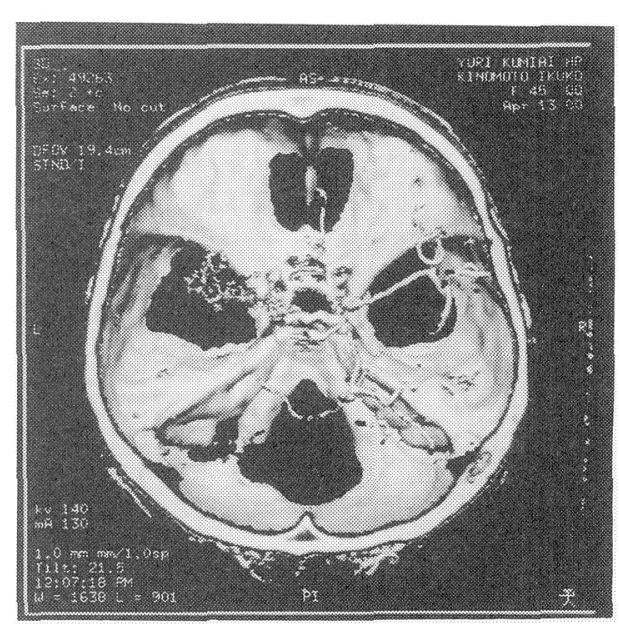




\section{E03 歯科医師のインフォームド・コンセントに関する意識調査}

\section{佐野祥平（さのしょうへい） \\ 北村中也、花岡 泉 \\ 鶴見大学菌学部予防㐘科学教室}

\section{歯科医療インフォームド・コンセント＼cjkstart歯科医師}

【目的】演者らは、昨年の本学会において 農村地域住民の歯科医療の受療状況や要 望、歯科医師の医の倫理観のとらえ方につ いてなどの調査を行った。その結果、歯科 医師への不満を持つ者が約 $40 \%$ 程度みら れた。その内容としては診療時間や期間、 回数等、受療に関することが多かった。ま た説明が不充分と回答した者も約 1 割程度 みられた。そこで演者らは、歯科医師の仢 フォームド・コンセントに対する意識および実践状 況に関する調査を行った。

【対象及び方法】対象は3歯科大学を卒業 し、回答の得られた歯科医師924名 (男性638 名、女性286名)である。質問項目は、本人の 属性の他、(1). 医の倫理に関する項目 (2). イン フォームド・コンセントに対する意識と実践状況であ る。調査は郵送法により調査を行った。

また、集計は勤務先の所在地により大都 市部 (政令市) ・市部・郡部に分けて行っ た。

【結果および考察】歯科医師が医の倫理に ついてどのように捉えているか知るため 「医は仁術の仁」の意味について質問した ところ各群とも「人命を尊ぶ博愛の道」と 回答した者が最も多く、郡部で 56.1\%、大 都市部・市部で 52.6\%と 44.9\%であった。

价ォームド・コンセント関する項目では、们 オームド・コンセ怆対する関心を知るため、「イ ンフォームド・コンセントに関する本を読んでいる か」の質問を行ったが、地域差はなく全体
でみると「常日頃読む」4.6\%、「時々読む」 ・「たまに読む」が 32.4\%と 47.5\%で多く、 「全く読まない」者も15.4\%みられていた。 价ォームド・コンセントの実践に心掛けている かの質問では地域により差がみられ、大都 市部、市部では「大いに心掛けている」と 答えた者がそれぞれ 53.4\%と 40.1\%であつ たのに対し、郡部では 26.3\%であった。郡 部では「心掛けている」と答えた者が最も 多く 71.9\%であった。また「心掛けていな いと答えた者は各群とも少なく $1.8 \%$ $0.8 \%$ と低い值を示した。

また、「价ォームド・コンセり」」実践が歯科 医療の質的向上に関連しているかの質問で は、各地域とも関連すると考えている者が 多く「大いに関連する」が $60.6 \%$ 、「関連 する」35.6\%が高く、「あまり関連しない」、 「全く関連しない」は $3.4 \%$ と $0.4 \%$ あるつ た。また「カルテの開示」については、「開 示す心゙き」は、大都市部が高く $8.1 \%$ 、郡 部では $3.5 \%$ であった。

このように歯科医師の傝ォームド・コンゼ卜 に関する意識は高かったが、大都市部で診 療している歯科医師は、价オームド・コンセント の実践やカルテの開示に積極的である傾向 が示された。しかしながら、その実践につ いては検討を要すると思われた。

【結論】歯科医師の价オームド・コンセントに関 する関心は高く大都市部、市部、郡部で大 きな異なりはみられなかった。 
2E04 高脂血症の栄盖指導におけるDHA含有補助食品の有用性

\author{
井齋偉矢 (いさい ひでや)
}

\title{
$\mathrm{J} \mathrm{A}$ 北海道厚生連鳥川厚生病院
}

高脂血症、栄養指導、DHA

＜緒言＞動眽硬化に対する栄養指導は、動物 性脂肪・コレステロール（CHO）摄取の制 限、植物性脂肪の奖励が中心で、総 $\mathrm{CHO}$ 値、 LDL-CHO值の低下に主眼が置かれている。 しかし、高CHO血症は必ずしも虚血性心疾 患の危険因子ではなく、むしろ $\omega 3 / \omega 6$ 比の 上昇の方が重要である。また、単に植物性脂 肪の摂取を梁励すると $\omega 6$ 多価不飽和脂肪酸 のとり過ぎを招く。そこで、高脂血症患者に DHA含有補助食品を撕取させることにより $\omega 3 / \omega 6$ 比を改善させ得るかを検討した。

<方法 $>2000$ 年1月に北海道勇払郡武川町民 を対象とした巡回ドックで高脂血症を指摘さ れた集団のうち治験参加を承諾した14名を 対象とした。承諾書は全員から書面で得た。 対象者には保健婦と栄盖士から生活・栄盖指 導がなされた。鐵引き法で対象を各々7名ず つDHA服用群（服用群）と非服用群（対照 群）に分けた。使用したDHA含有精製魚油 加工食品は「夕ムラDHA70」（田村薬品工 業社製）で、DHA含有量は $70 \%$ 以上、1鉈当 り124mgであった。服用群はDHAを毎日朝 食後に4錠、8週間服用した。服用開始日、8 週間後に総CHO、HDL-CHO、LDL-CHO、 中性脂肪、脂肪酸 24 分画を測定した。測定 值は平均土標淮誤差で表わし、推計学的検定 にはWilcoxon符号付順位検定を用い、危険 率5\%以下をもって有意とした。

<結果>対照群は男 3 例、女 4 例、服用群は 全例女性で、平均年齡は対照群 $58.4 \pm 4.6$ 歳、
服用群60.4 2.6歳であった。総CHOは服用 前で対照群 $236.9 \pm 9.9 \mathrm{mg} / \mathrm{dll}$ 、服用群 238.4 $\pm 9.9 \mathrm{mg} / \mathrm{dl}$ 、服用開始後 8 週で対照群 216.7 $\pm 11.4 \mathrm{mg} / \mathrm{dl}$ 、服用群 $237.6 \pm 8.6 \mathrm{mg} / \mathrm{dl}$ 有意差はなく、LDL-CHO、HDL-CHO、 中性脂肪も同様の傾向を示した。DHAは服 用前で対照群 $193.2 \pm 23.0 \mu \mathrm{g} / \mathrm{d} 1$ 、服用群 $184.3 \pm 16.4 \mu \mathrm{g} / \mathrm{d} 1$ 、服用開始後 8 週で対照群 $147.6 \pm 14.5 \mu \mathrm{g} / \mathrm{d}$ l、服用群 $178.2 \pm$ $9.4 \mu \mathrm{g} / \mathrm{dl}$ で、対照群の服用前值に比して 8週 後の值は有意に低值であった（P=0.0464）。 リノール酸は服用前で対照群 $770.4 \pm$ $21.7 \mu \mathrm{g} / \mathrm{dl}$ 、服用群859.5 $565.1 \mu \mathrm{g} / \mathrm{dl}$ 、服 用開始後 8 週で対照群666.8 $555.1 \mu \mathrm{g} / \mathrm{dl}$ 、服 用群 $657.1 \pm 43.1 \mu \mathrm{g} / \mathrm{dl}$ で、服用群の服用前 值に比して8週後の值は有意に低值であった $(\mathrm{P}=0.0180)$ 。 $\omega 3 / \omega 6$ 比は服用前で対照 群 $0.34 \pm 0.03$ 、服用群 $0.34 \pm 0.04$ 、服用開 始後 8 週で対照群 $0.33 \pm 0.03$ 、服用群 $0.38 \pm$ 0.04 で服用群に增加傾向があった。

<考察>DHA含有補助食品はCHO、中性脂 肪には影響を与えなかったが、対照群で有意 に減少したDHAを服用群では保ち、服用群 のリノール酸を有意に減少させ、その結果服 用群で $\omega 3 / \omega 6$ 比を増加させる傾向があった ことから、動脈硬化の進行予防に有用である と考えられた。

<結諭＞DHA含有補助食品は高脂血症の栄 養指導において考慮されるべき食品のひとつ になり得る。 
2E05 骨量隇少女性の女性ホルヒンン補充療法・ビタミンD療法の腰椎骨塩量に及ぼす影響

\author{
岩沖靖久 ${ }^{2}$ (いわ扔きやすひさ)

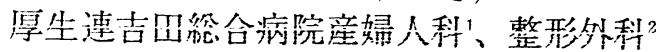 \\ 羽山友成、竹本正瑞、定地茂雄 ${ }^{2}$
}

胃是減少症、女性ホルモン補充療法・ビタミンD療法、月経歴別変化

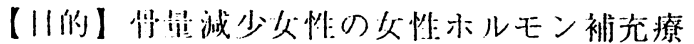

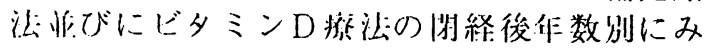

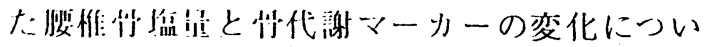

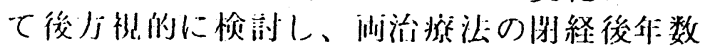
に上る孉い在㽗らかにすること。

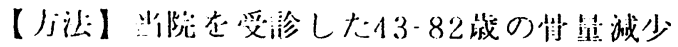

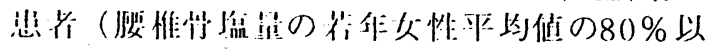

下）172名在刘爱とした。处性ホルモン補充

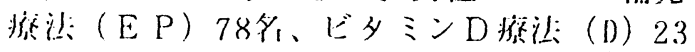

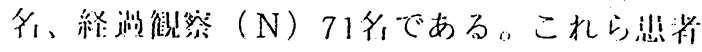

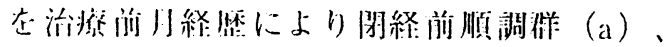

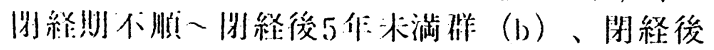

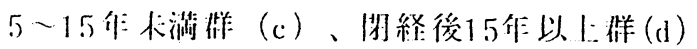

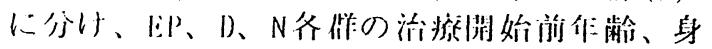

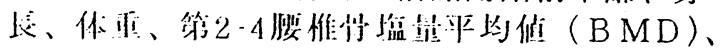
111 ルシシ人（Cａ）掑收量、微察期䦌を

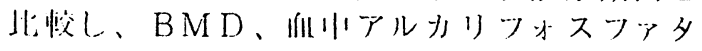
一七（ALP）、才ステォカルシン（OC）、

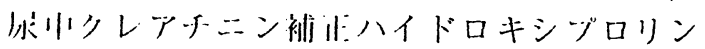

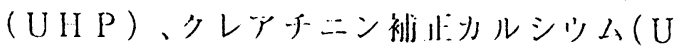

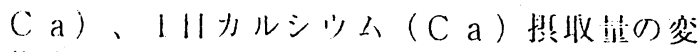

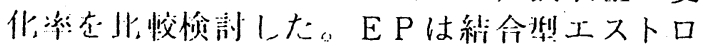
ダン0.62. $5 \mathrm{mg} / 11$ と陮陵メドロキジ゙ロゲス

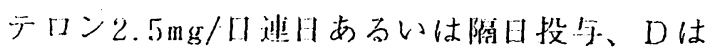

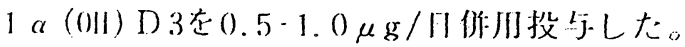

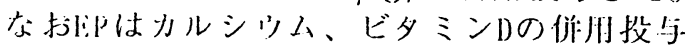
を命儿で㧍り、Dはカルシッ人の作凩投!占を 会んでいる。

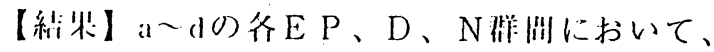

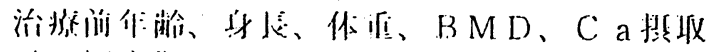

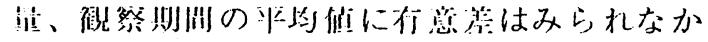
つた。 $\mathrm{a}$ dの各徽察期閏の平均值は各々 29 、 22、21、193月であった。BMD変化率は $\mathrm{E}$ $\mathrm{P}$ の $\sim \mathrm{d}$ が各々 -6、5、10、7\%、Dのb〜d が齐ター5、-2、2\%、Nの、ーdが齐ター3、ー2、 -1、-2\%で、b、c、オのE P と D、Nの間に 们意瘖态瑟めた $(\mathrm{P}<0.01)$ 。 A L Pの垐化 率は E P のーいが齐々ー $18 、-31 、-19 \%$ 、D のり〜いが各々・7、ー6、5\%、Nのり〜のが各々4、 -3、-5\%で、cのEPとN、はのE と D䦌に 付意差が存任した $(P<0.01)$ O O Cの変化 率はE Pのc、放备々-43、-41\%、Dのdが 17\%、NのC、dが各々 10、10\%で、cのE P とN、むのEPとD、Nの閉に有㮣差を認め た $(\mathrm{P}<0.05)$ U U H Pの変化率は E Pの $\mathrm{C} 、$

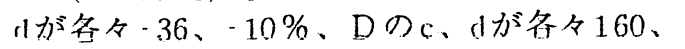
$24 \% 、 \mathrm{~N}$ c 、dが各々 $56 、 32 \%$ で、cの E P と D、Nの間に有意差があった（ $\mathrm{P} \leqq 0.01 ） 。$ $\mathrm{UC}$ a の変化率はE P の 、 d が各々 $23 、 48 \%$ 、

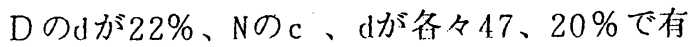
意着はみられなかった。C a 陉取量の変化率

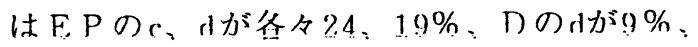
Nのc、』が条々ー3、11\%で有意差はなかっ た。

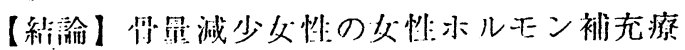
法は月経不順となる閉経周辺期より B MDの 有意な增加作用がみられ、䦥経後5 1 15年未 満の B M D 增州率が最も高く、この時期に骨 代謝マーカーのAＬＰ、OC、UH P の有意 な変化が認められた。ビタミンD療法は閣経 後15作以上の郡で B MD增加攧向を示した。 
2E06 消炎鎮痛剂の骨密度への影響

熊木昇二（くまきしょうじ）

長野県厚生連北信総合病院 整形外科

栗林秀樹

骨密度，消炎鎮痛剤

【目的】消炎鎮痛剂（以下NSAID）は腰痛 や関節痛などを和らげる目的で広く用いら れている。しか LNSAIDはプロスタグラン ジンの産生を抑制するため, 骨りモデリン グが阻害され, 骨密度 (以下BMD) を低下 させる可能性がある。われわれは, NSAID を 1 年以上にわたって使用した低骨量の症 例のBMDの変化と, NSAIDを使用しなかっ た症例のBMDの変化とを比較することで， NSAIDの骨密度への影響を知ることを目的 とした。

【対象 と方法】1999年4月1日から9月24 日までに当科で DXA法による腰椎および大 腿骨近位部のBMDを調べたものは272例あつ た。そのうちL2-4BMDかneckBMDのいず れかがYAMの $80 \%$ 以下で続発性でない症例 は，163例であった。この中でNSAIDを 1 年以上にわたり投与され，1 年間にわたっ てBMDの変化を観察できた14例を対象とし た（A:NSAID群）。コントロールとしては, NSAIDを定期的に投与されておらず， 1 年 間にわたってBMDの変化を観察できた 51 例 を用いた（B:非NSAID群）。

【結果】A群B群とも全例女性で, 年齢はA 群平均73.6歳（63-81歳）, $\mathrm{B}$ 群平均 71.7 歳 (57-87歳) で, 有意差を認めなかった $(\mathrm{p}=0.37)$ 。身長は, A群平均 $149.1 \mathrm{~cm}$ $(142-158 \mathrm{~cm})$, B群平均 $146.7 \mathrm{~cm}$ (127$157 \mathrm{~cm})$ で, 体重は, A群平均 $52.1 \mathrm{~kg}$ (41-
$73 \mathrm{~kg}), \mathrm{B}$ 群平均 $48.0 \mathrm{~kg}(33-64 \mathrm{~kg})$ で, ともに有意差を認めなかった $(\mathrm{p}=0.21 / \mathrm{p}$ $=0.11$ ）。骨粗影症治療薬（以下骨粗薬） は，A群で9例，64.9\%に使用されており， 内訳はビタミンK2が7例, エチドロネート が2例, カルシトニンが1例であった。 B 群 は27例，52.9\%で骨粗薬が使用されており， 内訳はビタミン $\mathrm{K} 2$ が13 例, エチドロネー トが10例, アルファカルシドールが4例で あった。A群でのNSAID 1 日あたり使用量 は, 常用量の $2 / 3$ 以上内服していたものが 9 例, $1 / 3 \sim 2 / 3$ が5例であった。 1 年間の $\mathrm{BMD}$ 変化率は, まず腰椎では, $\mathrm{L} 2 \mathrm{BMD}$ がA群で平均 $-2.7 \%$, B群で平均 $+2.9 \%$ ( $=0.064 ）, \mathrm{~L} 3 \mathrm{BMD}$ がA群で平均 $-5.9 \%$, $\mathrm{B}$ 群で+3.6\%（p=0.0026）, L4 BMDが $\mathrm{A}$ 群で平均 $-3.9 \%, \mathrm{~B}$ 群で+2.3\%（p= 0.054）, L2-4 BMDがA群で平均- $4.4 \%$, $\mathrm{B}$ 群で平均+ $2.8 \%(\mathrm{p}=0.0019)$ であった。 大腿骨近位部では, neck BMDがA群で平 均 $3.6 \%$, B群で平均 $-1.0 \%(\mathrm{p}=0.054)$, Wards BMDがA群で平均 $-4.6 \%$, B群で平 均 $+2.2 \%(p=0.019)$, troch BMDがA 群で平均 $-4.2 \%$, B群で平均 $+1.6 \%(\mathrm{p}=$ $0.017)$, total BMDがA群で平均 $-3.9 \%$, B群で平均 $+0.1 \%(\mathrm{p}=0.0018)$ であった。

【結論】NSAIDを長期に使用すると, 骨 密度が低下することが示唆された。 


\title{
$2 \mathrm{E} 07$ 脳神経外科領域における大豆蛋白質を配合した濃厚流動食 SoY の臨床的有用性の童価
}

\author{
袈澤 靖 \\ 鈴鹿中央総合病院 栄養サポートチーム \\ 東口高志 安井美和 谷口靖樹 二村昭彦 外川智子 清水敦哉
}

経腸栄養大豆蛋白質 血清脂質

脳神経外科領域において、救急医療の進歩に よって、従来では救命し得なかったような重症脳 卒中症例においてもその急性期を脱することが 可能となってきている。しかし、救命後に脳卒中 後遺症等で意識障害、鯂下障害などのために経口 摄取が不可能となり、経腸栄養法による栄養管理 が必要となる患者が増大している。現在、これら 脳卒中後遺症例等に対して広く経腸栄養が施行 されており、長期間にわたり栄養管理されている ケースが多い。また、これらの症例において冠動 脈心疾患や動脈硬化のリスクファクターである 血清コレステロール值の異常が多く認められる。 更に、長期にわたる経腸栄養施行症例の増加に伴 い、亜鉛 $(\mathrm{Zn}) 、$ 銅 $(\mathrm{Cu}) 、$ 、レン $(\mathrm{Se})$ などの必須微 量元素の欠乏症が問題になってきている。

近年、大豆蛋白質や大豆オリコ糖等の大豆成分 の生理作用が解明され、生活習慣病の予防・改善 に有用な食品素材として注目されている。特に、 大豆蛋白質は（1）血清脂質の改善（総コレステ ロールの低下、LDL-コレステロールの低下、およ びトリグリセライドの低下作用）、（2）抗肥満 効果、（3）リノール酸代謝の抑制、（4）系球 体濾過率 (GFR) の低下の抑制等が報告されている。 また、大豆オリゴ糖は腸内細菌叢の改善効果あり、 便通改善に有効であることが多数報告されてい る。更に、大豆には必須微量元素である亜鉛 $(\mathrm{Zn}) 、$

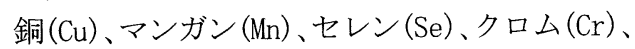
モリブデン (Mo)が豊富に含まれていることが知 られている。今回、大豆蛋白質を主蛋白質源とし、 大豆オリゴ糖、および大豆由来の必須微量元素

$(\mathrm{Zn} 、 \mathrm{Cu} 、 \mathrm{Mn} 、 \mathrm{Se} 、 \mathrm{Cr} 、 \mathrm{Mo})$ を配合した液 状濃厚流動食「SOY」を脳神経外科領域の患者に 投与し、その臨床的有用性について評価したので、 その結果について報告する。

\section{1. 対象}

対象は当院の脳神経外科および外科に入院し 経腸栄養を必要とする患者 10 例とした。投与期 間は 4 週間とした。性別は男性 5 例、女性 5 例で、
年齢は $71.9 \pm 9.0$ 歳であり、原因疾患は脳梗塞 5 例、くも膜下出血 3 例、脳内出血 1 例、聴神経腫 瘍 1 例である。

\section{3. 結果}

（1）血液生化学検査

栄養指標として有用である Alb は投与前 $3.4 \pm$ $0.4 \mathrm{~g} / \mathrm{dl}$ から 4 週目 $3.7 \pm 0.5 \mathrm{~g} / \mathrm{dl}$ には有意な $(\mathrm{p}<0.05)$ 上昇を示した。また、Alb $<3.5 \mathrm{~g} / \mathrm{d} 1$ の低 栄養状態にある 7 症例においても、2 週目 $3.2 \pm$ $0.6 \mathrm{~g} / \mathrm{dl}$ から 4 週目 $3.5 \pm 0.5 \mathrm{~g} / \mathrm{d} 1$ には有意な $(\mathrm{p}<0.05)$ 上昇を示した。一方、TP は投与前 6.1 $\pm 0.6 \mathrm{~g} / \mathrm{dl}$ から 4 週目 $6.5 \pm 0.6 \mathrm{~g} / \mathrm{d} 1$ まで上昇傾 向であったが有意ではなかった。しかし、正常値 以下 $(\mathrm{TP}<6.7 \mathrm{~g} / \mathrm{d} 1)$ の 9 症例では、投与前 6.1 $\pm 0.5 \mathrm{~g} / \mathrm{d} 1$ から 4 週目 $6.5 \pm 0.5 \mathrm{~g} / \mathrm{d} 1$ には有意な $(\mathrm{p}<0.05)$ 上昇が認められた。

$\mathrm{TC}$ は $220 \mathrm{mg} / \mathrm{dl}$ 以上の高コレステロール血症 の 5 症例では、投与前 $250 \pm 22 \mathrm{mg} / \mathrm{dl}$ から 4 週目 $216 \pm 37 \mathrm{mg} / \mathrm{d} 1$ には正常範囲内まで有意 $(\mathrm{p}<0.05)$ に低下し、投与前值に比較して $13.6 \%$ の低下が観 察された。また、TG も同様に $150 \mathrm{mg} / \mathrm{d} l$ 以上の 6 症例において、投与前 $174 \pm 12 \mathrm{mg} / \mathrm{d} 1$ から 4 週目 $144 \pm 25 \mathrm{mg} / \mathrm{d} 1$ には正常範囲内まで有意 $(\mathrm{p}<0.05)$ に 17.2\%低下した。一方、TC<220mg/dl および $\mathrm{T} G<150 \mathrm{mg} / \mathrm{d} 1$ の正常範囲内の症例は共に有意な変 化は認められなかった。また、HDL-Ch の測定は 3 例のみであったが上昇傾向であった.

肝機能およびChE、BUNおよび Cr は有意な変動 を示さなかった。

血清電解質 $\mathrm{Na} 、 \mathrm{~K} 、 \mathrm{Cl}$ は投与前と同一レベルで維 持され、特に有意な変化はなかった。血清 Ca は 投与前 $8.9 \pm 0.6 \mathrm{mg} / \mathrm{dl}$ から 4 週目 $9.5 \pm 0.4$ $\mathrm{mg} / \mathrm{d} 1$ と正常範囲内の変化であったが有意 （p<0.05）に上昇した。 
510

治験コーディネーター

$2 \mathrm{E} 08$ 外来における治験コーディネーター業務の実践

間瀬 悟1）（ませ さとる）

J A 愛知厚生連 更生病院 薬郕科1) 循環器内科2)

足助病院 薬剂科 3 杉浦 千恵1)、三浦 崇則 1 )

太田 満1)、水谷 勝1)、鷹津 文榣2)、神谷 恒行3）

治験、治験コーディネーター、C R C

【目的】治験が適正かつ円滑に実施されるた めに治験コーディネーター（Clinical

Research Coordinator : 以下 CRC) の役割 が重要視されてきている。当院薬剤科では、 これまで主に入院患者を対象とした治験に 対して、病棟薬羭師が CRC 業務を兼務して いた。そして最近では、外来で実施される治 験に対しても、治験協力依頼の要望が高ま ってきている。現在、我々は外来における治 験に対して、薬剤師が CRC として関わって いくための CRC 業務体制づくりを行ってい る。今回、我々が取り組んでいる臨床試験 を例にあげ、治験（臨床試験）に関する薬剤 師の役割について報告する。

【方法】以前より当院循環器内科から治験協 力依頼のあった臨床試験（試験名 : JELIS） について CRC として関わった。CRC は通常、 外来調剤室で調剤業務に携わる薬剤師 3 名 が担当し、試験実施のための計画・立案お よびCRC 業務を行った。対象患者のスクリ 一ニングは医師が行い、外来診察室にて医師 による試験の主な説明が行われた後、患者に この試験に対するより詳しいインフォーム ドコンセントを CRC が行った。インフォーム ドコンセントは平成 11 年 7 月 12 日から平成 11 年 9 月 2 日迄の期間（約 1 ケ月半）に医 師より依頼のあった患者、合計 55 名に対し て行った。同意取得後、同意文書作成作業お よび同意書のカルテへの貼付、コーディネー トセンターへの割付依頼は CRC が行った。
【結果・考察】試験実施前の活動した具体例 として (1) 試験実施フローチャートの作成、 （2）患者用説明用紙の作成、（3）CRC 用 の業務項目別チェックリストの作成、 治験専用の検查依頼票の作成、（5）患者の スケジュール管理体制の整備、（6）臨床試 験薬の投薬マニュアルの作成、（7）外注検 調査の一元化などを行った。これらの業務を 薬剤師が行ったことにより、医師からは、通 常の外来診察を妨げることなく多くの治験 参加者のエントリーができるようになり、 好評であった。しかしながら、説明に用い た患者用説明用紙が、患者にとって理解し やすかったかどうかは、今後、さらに詳細 な調査が必要であると思われる。また、専 用の検査依頼票を利用したことによって、 今のところは治験に必須な検査項目は見落 としなく実施されている。今回の臨床試験 において、試験期間 5 年間のうち、CRC とし て我々が患者に直接面談できるのは試験開 始後 6 ケ月とその後、毎年一回しかないため、 患者が試験の続行不可能になるような場合 には、患者より直接的な相談を受けない限り、 CRC が迅速に対応できない可能性があると考 えられる。したがって、今後の課題として今 回の取り組みを客観的に評価した上で、より きめ細かなフォローを行うためには何をす べきか? について検討し、患者が安心して試 験期間の 5 年間を完遂できるように取り組 んでいきたいと考えている。 
2E09 当院における薬剤師 C R C (治験コーディネーター) への取り組み

岡沢香津子（おかざわかつこ）

JA長野厚生連北信総合病院 薬剤科

渡辺英理子 松永きよ美 土屋美千子 高野三男

治験、CRC

\section{[目的]}

従来治験は、大学病院や国立病院を中心 に実施されてきたが、新 G C P 施行後治験 実施数は減少し、国内における治験の空洞 化が懸念されている。このため、身近な医 療機関のレベルアップが治験の推進に必要 とされ、地域の基幹病院の治験における役 割が重要視されつつある。

当院では、新 G C P 施行以前より薬剤師 が治験事務局業務を行ってきた。このたび、 さらに治験に関するチーム医療に参画し、 院内及び被験者の調整役として治験の円滑 化に寄与することを目的に、薬剤師 C R C を導人した。てい経䋨と內容について䋸告 する。

\section{[経赭]}

平成3年4月 G C P 施行、北信総合病院 治験審査委員会を組織し薬局長が治験事務 局を担当薬剤科による治験薬の一元管理を 開始する。

平成9年4月 新 G C P 施行、薬剂科医薬 品情報管理室主任が治験事務局を担当

平成 10 年 4 月 新 G C P 完全実施

平成 10 年 6 月 新 G C P への院内整備完 了、受け入れ開始

平成 11 年 11 月 新規 1 件 16 症例に対し薬 剤師3名（兼任）により C R C 業務開始

\section{[業務内容]}

(1)インフォームド・コンセントの日時の 設定と補助説明

(2)服薬指導、残薬回収、併用禁止薬和少

(3)検査スケジュール管理

(4)来院日の検査伝票・外注用試験管の力 ルテへの挟み込み

(5)来院前日の電話連絡

(6)電話でのコンプライアンスのチェック

(7)検査データの早期チェック

8)被験者の相談空口

\section{[まとめ]}

C R C を導入したことにより、下記のよ うなメリットが考えられる。

(1)併用禁止薬のチェックにより、プロト コール違反を未然に防止（2 例）

(2)服薬指導の徹底によるコンプライアン スの確保

(3)有害事象や市販薬服用についての患者 からの相談に対し、スムーズな対応

このように薬剤師の職能を生かした C R C 業務を展開することにより、質の高い治 験の実施と被験者の倫理面での保護が可能 になる。今後は、患者及び院内スタッフか らのC R C 業務の評価を行い、その有用性 について検証していく必要がある。 


\title{
$2 \mathrm{E} 10 \quad$ 治験コーディネーターを導入して
}

\author{
成皇 桼子(なるしまやすこ) \\ 取于泇同病院 外来 \\ 菻永 楩代
}

インソォームド・コンヒント、文書同意

\section{【はじめに】}

1998 年 4 月に新 G C P (医薬品の臨床試験 の実施の基準) において、治験コーディネー ター(以下 C R C と略す)が位置付汀られた。

これに伴って当院に挄ても、1999 年 4 月 より外来業務でC R Cを導入 1 年が経過した。 C R C 導入は治験希望者に対する信頼関係と インフォームド・コンセントにより、25名中 20 名の文書同意を得ることができた。この事 により C R Cの役割の必要性を認識した。又、 同意を得なかった内容についても検討したの で報告する。

\section{【期間】}

1999 年 4 月 2000 年 3 月

\section{【対象】}

高血圧症と、骨粗鬆症の被験薬希望者及び 治験薬エントリー可能者

\section{【方法】}

ポスター掲示、治験可能者への烀びかけ、 健康センターへの連携により募集、治験担当 医師より治験可能と判断された場合 C R Cに 連絡あり、(1)資料に基づき内容の説明、(2)厚 生省企画 “くすりができるまで”のビデオの 活用、(3)家族への資料説明を実施した。そし て、自由意思に基づいて治験に参加できるよ う説明資料を渡し家族への閲覧も勧めた。

\section{【結果・考察】}

C R C 面談結果は、25名中、文書同意 20 名、 同意拒否 3 名、適応基準外 2 名であった。被 験者加らの電話相談の対応、外来当日診察前
の面談、ケアーなどプライマリーで接する事 により信頼関係ができ、3 名が終了し現在 7 名が継続中である。他の10 名は治験期間中に、 湿绦の副作用で 1 名、治験への不安感から脱 落で 1 名、適态基準外となった中止者 8 名で あった。同意拒否 3 名は、説明を受けなか力 た家族からの反対、又、治験への不安からで あった。湿疹出現者は皮膚科受診となったが、 脱落者や同意拒否者の治験への不安感は大き いと思われ、CRCとして心の把握、薬の把 握、役割の把握の重要性を感じ、被験者や家 族へ十分に知らされた上で納得するインフォ ームド・コンセントの必要性を認識した。そ のため今後、CRCとしての業務内容を見直 し、自己学習を梁めなければならないと考え る。

\section{【おおりに】}

今回、治験コーディネーターとしての役割 を学び必要性を認識した。今後、被験者が安 心して治験に参加できるよう、治験コーディ ネーターとして知識を深め、いかなる場面に おいても対灾できるよう努力していきたい。 


\section{薬㨈・業務拡大}

$2 \mathrm{E} 11$ 当院の喘息教室における薬剤師の役割

箱浩浩呆

土浦協同病院薬剂科

并坂敦子関富美子 田上 贵美子福島 智子 白士 敦子

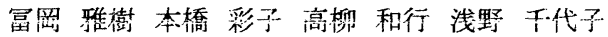

喘息

\section{【はじめに】}

当院では、平成9年より小児喘息教室、平成1 1年より成人喘息教室に薬剂師が参加し患者教 淯をおこなっている。喘息教室は、医師、看護 婦、保育士、薬剂師が、協力して運営を行って いる。薬剂科内では喘息教室のグループを決 め教育内容の検討を行っている。喘息治療で は吸入薬、内服薬、則薬沈ざ多種多様な剂形 の薬が用いられるため、それぞれの薬の特性を 最大限に発揮するためには患者教育が必要不 可欠である。今回喘息教室を通して薬剂師の喘 息治療における役割について検討したので報 告する。

\section{【 方法 】}

\section{1)パンフレットの作成}

小児喘息教室に対し薬物療法のパンフレットく すりのしおり」、成人喘息教室に対し喘息教室 パンフレットの「喘息に使われるくすり」作成

2)各教室へ講師派遣

小児喘息教室のスケジュール

\begin{tabular}{|c|c|c|c|c|c|}
\hline \multicolumn{2}{|c|}{ 日 䁃(1330 1430) } & \multirow[b]{2}{*}{ 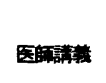 } & \multirow[b]{2}{*}{ 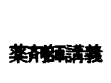 } & \multirow[b]{2}{*}{ 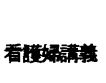 } & \multirow[b]{2}{*}{ 保育士 } \\
\hline 1回目 & 2回目 & & & & \\
\hline 4月13日 & 10月12日 & $\begin{array}{c}\text { 喘息につい } \\
\tau\end{array}$ & & 日常生活 & 峨艺居 \\
\hline 5月11日 & 11月9日 & $\begin{array}{c}\text { アルルギ } \\
\text { 険查 }\end{array}$ & $\begin{array}{c}\text { 来の㮔類と } \\
\text { 使い方 }\end{array}$ & & 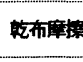 \\
\hline 6月8日 & 12月14日 & 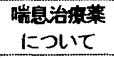 & & $\begin{array}{c}\text { 上手な菜の } \\
\text { 䚺夫ま方 }\end{array}$ & 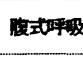 \\
\hline 7月13日 & 1月11日 & $\begin{array}{c}\text { 日常生活の } \\
\text { 対策法 }\end{array}$ & $\begin{array}{c}\text { 莱の主作用 } \\
\text { 副作用 }\end{array}$ & & 乾布麻堷 \\
\hline 8月17日 & 2月8日 & $\begin{array}{l}\text { 発作時の } \\
\text { 対策法 }\end{array}$ & & $\begin{array}{c}\text { 正Ll吸入 } \\
\text { 法 }\end{array}$ & 腹式呼吸 \\
\hline 9月14日 & 3月14日 & まとめ & まとめ & & 䡉布库泣 \\
\hline
\end{tabular}

成人喘息教室スケジュール

\begin{tabular}{|c|c|c|}
\hline 月日 & 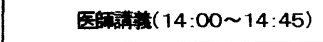 & 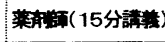 \\
\hline 10月18日 & 喘息ってどんな病赵 & 薬の種類と使い方 \\
\hline
\end{tabular}

\begin{tabular}{|c|c|c|}
\hline 11月15日 & 日常生活の注意点 & 自分の莱を知ろう \\
\hline 12月20日 & 発作が起きてしまったら、どうすればよいか & 吸入莱の使用法 \\
\hline 1月17日 & $\begin{array}{l}\text { 内没しているお菜及入葉の效果が分かります } \\
\text { か }\end{array}$ & 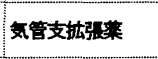 \\
\hline 2月21日 & $\begin{array}{l}\text { 吸入㩧法は、なぜ、毎日行わなければならな } \\
\text { いのか }\end{array}$ & アルルギー葉 \\
\hline 3月27日 & 喘息の自己管理 & まとめ \\
\hline
\end{tabular}

3) 小児喘息教室で保護者に対しアンケート調 查実施 (99/5/11、99/7/13、99/9/14)

【結果】

アンケート結果

\begin{tabular}{|c|c|c|c|}
\hline 質問内容／月 & 5月 & 7月 & 9月 \\
\hline (1)薬の名前を知っている & $66 \%$ & $100 \%$ & $100 \%$ \\
\hline (2)主治医から莱の説明を受けたこことがある & $100 \%$ & $100 \%$ & $100 \%$ \\
\hline (3)萁用师から萧の説明を受けたこことがある & $44 \%$ & $37 \%$ & $28 \%$ \\
\hline (4)萧放柚報提供を受けたことがある & $22 \%$ & $50 \%$ & $42 \%$ \\
\hline (5)主治医の指示二従つて乗夲服用している & $44 \%$ & $87 \%$ & $100 \%$ \\
\hline (6)菜の服用を時々忘れる & $44 \%$ & $12 \%$ & $0 \%$ \\
\hline (フ自己判断で檴を服用している & $22 \%$ & $12 \%$ & $0 \%$ \\
\hline
\end{tabular}

\section{【考察】}

小児喘息教室のアンケートの結果より薬の名 前については $100 \%$ 理解している。服薬コンプ ライアンスについても7月にはすべての患者さ 几が医師の指示通り服用していることがわかつ た。このことは、喘息教室に、薬剤師が参加する ことにより、患者さんが医師、看護婦とは違った 視点で薬の特性について理解できたと思われ る。

\section{【まとめ】}

医療スタッフの一員として薬剤師が職能を生 かし教室に参加することは、患者さんが薬の特 性を理解し、適正使用する事により、副作用が 防げ、効果的に薬を使用できることから、喘息 患者さんのQOL向上に貢献できると考える。 
$2 \mathrm{E} 12$ 当院の薬剂管理指導業務への取り組みと業務支援システム

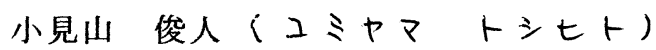

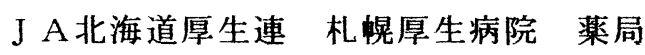

$$
\begin{aligned}
& \text { 早川 達・下山 光一・関谷 繁 }
\end{aligned}
$$

当院における薬剤管理指導業務は平成 8 年 より開始され、現在は 3 病棟を 4 名の担当薬 剤師により行われている。対象診療科は内科 - 消化器科・循環器科・呼吸器科・耳鼻科と 多岐にわたっており病態も様々である。服薬 指導は患者の病態と使用薬に対する正確な知 識の確保、並びにコンプライアンスの向上を 図ることを目的とし固別に指導を行い、患者 並びに病棟スタッフより評価を得ている。ま た、患者に使用される楽剤の併用禁忌・重複 第 投与等のチェックや副作用モニターは業務上 重要な情報であり随時医師へフィードバック を行っている。しかしながら、最近では担当 病棟が増加することにより薬歴等の作成に時 間を要することが多くなり、ベットサイドへ 赴く時閒的な制限が発生していることも夏慮 された。そこで、薬歴作成の時間短縮を考慮 しオーダリングシステムのデータを用いたシ ステムを作成することとなった。今回、我々 は薬剤管理指導業務における副作用モニター の成果と、オーダリングシステムを利用した 薬剂管理指導業務支援システムについて報告 する。 


\section{$2 \mathrm{E} 13$ 薬剤待ち時間短縮への改善策とオーダリングシステム導入による効果}

小磯 雄一 (こいそゆういち)

取手協同病院 薬剂科

堀越建一、幕内 誠一大串 和子

薬剂待ち時間、外来オーダリングシステム、患者サービス

【はじめに】我々病院薬剤師には、患者への 薬剂情報提供など、サービスの質の充実を図 る一方で、薬剤待ち時間の短縮もその一環と して求められている。また、常に患者の満足 を意識しながら活動する必要がある。当薬剤 科では、外来患者の待ち時間を調査し、待ち 時閒短縮のためにいくつかの改善策を実施し た。さらに、H12 年 3 月より外来オーダリン グシステムを導入したことで、待ち時間への 好影響が期待された。そこで、システム導入 前後における薬剂待ち時間の変化を調査検討 したので報告する。

【方法】医事会計受付から薬剤交付までを待 ち時間とし、オーダリングシステム導入前 (H 11 年 11 月 29 日 12 月 3 日) 及び導入後 $(\mathrm{H}$ 12 年 4 月 4 日〜 10 日) について、診療開始加 ら 13 時までを 30 分単位に区切り、処方箋枚 数および待ち時閒を調査し比較を行った。

【結果・考察】薬剂科内で次のような改善策 を実施した。(1)繁用薬剂の繁用数量でのセッ 卜化(2)散薬約束処方の追加(3)機器トラブル発 生時の対応法を確立(4)その他。これらの改善 に続き、オーダリングシステムを導入した。1 日の処方箋枚数に対守万時間鱼別処方篦枚数 の割合を比較した(図 1)。システム導入前と 比較して、導入後には 9 時から 10 時の時間帯 に処方箋数が多く、11 時以降の時間帯に少な い傾向にあった。薬剂待ち時間は、システム 導入後にすべての時間帯で短縮された。シス テム導入前と比較した短縮率は、最低 $25.3 \%$ 、 最高 $89.0 \%$ 、平均 $57.1 \%$ であった(図 2 )。
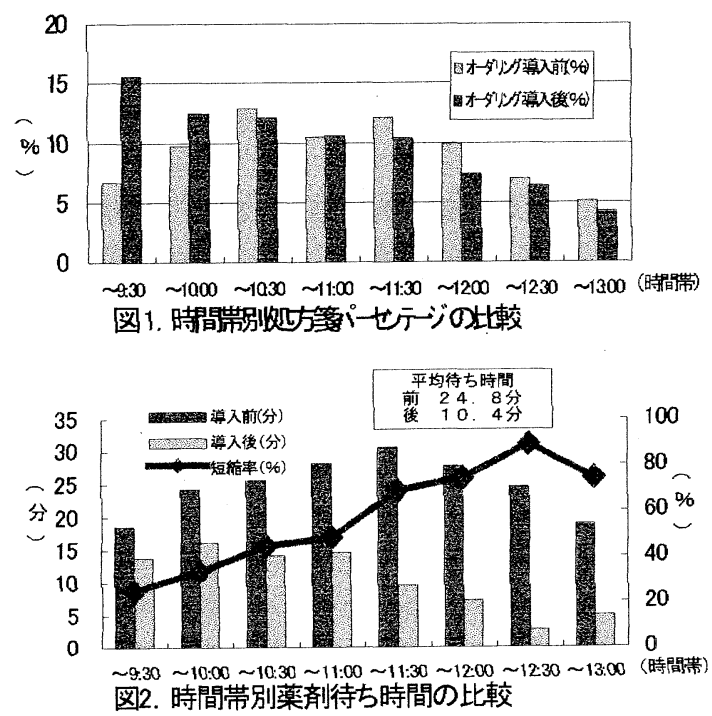

システム導入後は 9 時 30 分までの時間带で処 方箋割合が最高となった。このため、待ち時 間の短縮率は $25.3 \%$ と最小となったと考え られ、この時間帯のさらなる業務改善が必要 となった。しかし、システム導入前の待ち時 間は 11 時〜11 時 30 分にピークを描くのに対 し、導入後は時間帯による変動が少なくほぼ 一定といえる。また、すべての時閒帯で待ち 時間は短縮しており、平均待ち時間も 24.8 分から 10.4 分と減少し、患者サービスに寄与 できたといえる。

【まとめ】薬剤待ち時間短縮のため薬剂科内 でいくつかの改善を実施、さらに外来才ーダ リングシステムを導入し、平均待ち時間を 24.8 分から 10.4 分に短縮することができた。 今後も定期的に待ち時間調查を行い、患者少 ービス向上に努めていきたい。 
2E14 血圧日内変動測定法を利用した高血圧患者の薬剤管理指導の有用性

菏合洋 (岐北総合病院薬剤部)

安田 洋、新井 正、伊東祐二、早川和良、平野良尚、 高屋忠丈、篠田道夫、樫木良友

血圧の日内変動 高血圧患者の薬剂管理指導 携帯型自動血圧計

\section{【はじめに】}

高血圧には、早朝血圧が上昇する morning surge や夜間血圧が低下しない non-dipper が存在し、これらの高血圧は 脳・心血管障害を来たすことが多いといわれ ている。また、病院で血圧が上昇する白衣高 血圧も存在している。

一方、高血圧患者の治療は、病院で測定さ れた随時血圧と家庭で測定した血圧值を参 考として治療されているのが現状といえる。 また、高血圧患者に対する薬剤管理指導もそ の随時血圧をもとに指導し、患者の血圧の日 内変動を理解しないまま指導しているのが 現状といえる。そこで以前より当院では、高 血圧症あるいは低血圧症の入院患者や外来 患者を対象に、携帯型自動血圧計 (ABPM) を利用して血圧の日内変動を測定し、高血圧 の治療や薬凨管理指導に利用する試みを行 ってきた。その結果、 $\mathrm{ABPM}$ を利用して血 圧の日内変動を測定することは、高血圧の治 療や薬荗管理指導に有効であったと報告し た。

これらのことを踏まえ今回私たちは、患者 が血圧の日内変動測定をどのように考えて いるか調查することにより、患者の立場から 血圧の日内変動の有用性について調查した。

\section{【方法】}

当院で $\mathrm{ABPM}$ を利用して血圧の日内変動 の測定を行った入院あるいは外来患者を対 象に、血圧の日内変動測定に関するアンケー トを行った。また同時に血圧の日内変動、高 血圧に関するパンフレットを配布した。

[アンケート内容]

自分の血圧の日内変動測定について
(1) 携帯型血圧計の装着が嫌でした か?

(2) 夜は眠れましたか?

(3) 行動の妨げになりましたか?

(4) 家庭で自分の血圧を測定したこと がありますか?

(5) 前から血圧には日内変動があるこ とを知っていましたか?

(6) 自分の血圧の日内変動を知ること により、服薬意識が変わりました か?

(7) また自分の血圧の日内変動を測定 してみたいですか?

\section{【結果】}

患者の多くは、携帯型自動血圧計を用いて 自分の血圧の日内変動を測定し理解するこ とにより、血圧に対する認識が高まり服薬意 識が向上した。

\section{【考察】}

生体リズム障害を来たしている患者や morning surge や non-dipper の患者に対 しては、薬凨管理指導を通して患者自身の血 圧の日内変動を説明することにより服薬意 義の理解が增し、コンプライアンスの向上に つながると考えられる。今後薬剤師は、高血 圧指導など $\mathrm{ABPM}$ により血圧の日内変動を 調査し、患者個人にあった降圧薬の服用方法、 投与量、併用薬などを医師と検討し、さらに 患者に説明することが、より有効な血圧療法 につながると考えられた。

\section{【文献】}

河合洋, 安田洋, 新井正, 他: 血圧日内変動 測定法を利用した高血圧患者の服薬指導の 有用性. 診断と新薬 $35(5): 71 \sim 73,1998$ 